Daniel Luiz Rodrigues Junior

EFEITO DO TAMANHO DE GRÃO E DA INDUÇÃO MAGNÉTICA SOBRE O CAMPO COERCIVO E DISSIPAÇÃO DE ENERGIA POR HISTERESE EM AÇOS PARA FINS ELÉTRICOS 
Daniel Luiz Rodrigues Junior

\section{EFEITO DO TAMANHO DE GRÃO E DA INDUÇÃO MAGNÉTICA SOBRE O CAMPO COERCIVO E DISSIPAÇÃO DE ENERGIA POR HISTERESE EM AÇOS PARA FINS ELÉTRICOS}

Dissertação apresentada á Escola Politécnica da Universidade de São Paulo para obtenção do título de mestre em engenharia.

Área de concentração: Engenharia Metalúrgica e de Materiais.

Orientador: Professor Doutor Fernando José Gomes Landgraf.

\section{São Paulo}

2010 
Este exemplar foi revisado e alterado em relação à versão original, sob responsabilidade única do autor e com a anuência de seu orientador.

São Paulo, 20 de janeiro de 2010.

Assinatura do autor

Assinatura do orientador

\section{FICHA CATALOGRÁFICA}

Rodrigues Junior, Daniel Luiz

Efeito do tamanho de grão e da indução magnética sobre o campo coercivo e dissipação de energia por histerese em aços para fins elétricos / D.L. Rodrigues Junior. -- ed.rev. -- São Paulo, 2010.

$119 \mathrm{p}$.

Dissertação (Mestrado) - Escola Politécnica da Universidade de São Paulo. Departamento de Engenharia Metalúrgica e de Materiais.

1. Materiais magnéticos I. Universidade de São Paulo. Escola Politécnica. Departamento de Engenharia Metalúrgica e de Materiais II. $t$. 
Alos meus pais, Daniel Luiz Ro drigues e Neusa Pereira Rodri ̧ues. São eles os meus maiores exemplos, melhores amigos \& grandes incentivadores. 


\section{AgRADECIMENTOS}

Ao professor Dr. Fernando José Gomes Landgraf, orientador desse trabalho.

Ao Conselho Nacional de Desenvolvimento Científico e Tecnológico - CNPq pelo apoio financeiro.

À Cosipa pela doação de matéria prima utilizada na realização desse trabalho.

Ao Laboratório de Metalurgia do Pó e Materiais Magnéticos do Instituto de Pesquisas Tecnológicas - ITP por gentilmente disponibilizar equipamentos para a realização de parte do procedimento experimental desse trabalho.

Ao professor Dr. Ronald Lesley Plaut (PMT-USP) e à Sandra Munarin (IPT) que executaram o processo de laminação das amostras.

Às empresas Embraco e SEW Eurodrive responsáveis pelo recozimento das amostras.

Funcionários do laboratório de metalografia Hubertus Colpaert.

Ao professor Dr. André Paulo Tschptschin que viabilizou parte da etapa de caracterização microestrutural.

Aos amigos do "Grupo do tamanho de grão", equipe de trabalho dedicada a investigar as relações entre tamanho de grão e propriedades magnéticas.

Aos amigos da turma 031 do curso de Materiais Processos e Componentes Eletrônicos (MPCE) da FATEC-SP. 


\section{RESUMO}

Este trabalho discute o efeito do tamanho de grão e sobre o campo coercivo e perdas magnéticas em aços elétricos. Também foi avaliado o efeito da indução máxima sobre o campo coercivo.

Partindo-se de chapas de aço elétrico $0,7 \%$ Si, extraídas de uma mesma bobina foram obtidos conjuntos de amostras com diferentes tamanhos de grão, na faixa entre 10 a $150 \mu \mathrm{m}$. Os diferentes tamanhos de grão foram medidos por dois métodos distintos: aumento do tamanho de grão por recristalização e aumento do tamanho de grão por crescimento. Sete conjuntos foram laminados, cada conjunto com um determinado grau de laminação, e posteriormente os conjuntos foram recozidos para sofrerem aumento do tamanho de grão por recristalização. Outros três conjuntos foram somente recozidos em tempos e temperaturas distintos e o aumento do tamanho de grão se deu por crescimento. Um conjunto passou por tratamento térmico para alívio das tensões introduzidas no corte.

Os tamanhos de grão foram medidos por um método de análise semiautomático envolvendo a medição das áreas dos grãos individualmente e também pelo método dos interceptos. A caracterização magnética foi executada em regime quase estático para as induções máximas de 0,$6 ; 0,8 ; 1,0 ; 1,2 ; 1,4$ e $1,5 \mathrm{~T}$ e a $60 \mathrm{~Hz}$ para 1,0 e 1,5T. Os resultados mostram uma relação de linearidade entre o campo coercivo e o inverso do tamanho de grão. As perdas histeréticas apresentam crescimento determinado por uma lei de potência com relação à indução máxima.

Palavras-chaves: aço elétrico, campo coercivo, perda histerética, recristalização, crescimento de grão. 


\section{ABSTRACT}

This work discusses about grain size effect on the coercive field and magnetic losses in electrical steel. Also, it was evaluated the maximum induction effect on the coercive field and hysteresis loss.

Starting from $0,7 \%$ Si electrical steel sheet sets of samples with different grain sizes in the range between 10 to $150 \mu \mathrm{m}$ were obtained. The different grain sizes were obtained by two different methods: grain size increase by recrystallization and grain size increase by grain growth. Seven sets were cold rolled, each set with a cold work degree. Three other sets were only annealed at different times and temperatures and the increase in grain size was characterized by growth. A set underwent heat treatment to relieve the stress brought into cut.

The grain sizes were measured by a method of analysis involving semiautomatic measurement of areas of individual grains and also by the method of intercepts. The magnetic characterization was performed under quasi-static regime for the maximum inductions of $0.6,0.8,1.0,1.2,1.4$ and $1.5 \mathrm{~T}$ and $60 \mathrm{~Hz}$ for 1.0 and $1.5 \mathrm{~T}$. The results show a linear relation between the coercive field and the inverse grain size. Hysteresis losses presented a growth determined by a power law with respect to the maximal induction.

Keywords: electrical steel, coercive field, hysteretic loss, recrystallization, grain growth. 


\section{LISTA DE FIGURAS}

Figura 1: Participação da produção dos diferentes materiais magneticamente moles.

Figura 2: Representação dos spins eletrônicos na camada 3d para um átomo de um elemento diamagnético (a) e um ferromagnético (b) ................................. 7

Figura 3: Exemplo de curva de magnetização de um material ferromagnético. ...... 8 Figura 4: Ilustração da estrutura de domínios magnéticos em um material

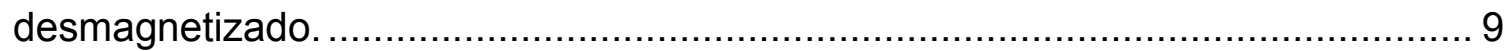
Figura 5: Mudança gradual na orientação dos dipolos através da parede de domínio.

Figura 6: Configuração da estrutura de domínios no decorrer do processo de magnetização.

Figura 7: Curva de magnetização com o campo magnético aplicado em três direções cristalinas distintas de um monocristal.

Figura 8: Ciclo de histerese magnética e seus principais pontos. 13

Figura 9: Ilustração mostrando correntes induzidas $\mathrm{i}(\mathrm{t})$ (correntes parasitas) por uma indução magnética $\mathrm{B}(\mathrm{t})$ que varia com o tempo. 15

Figura 10: Ilustração do empacotamento de chapas de pequena espessura para a redução da perda por corrente parasita clássica.. 16

Figura 11: Gráfico ilustrando o comportamento da dissipação de energia em função da freqüência.

Figura 12: Gráfico da resistividade elétrica em função do teor de silício para aços elétricos.

Figura 13: Gráfico das perdas totais a $50 \mathrm{~Hz}$ em função do teor de silício para 1 e $1,5 \mathrm{~T}$.

Figura 14: Efeito do teor de alumínio sobre a resistividade de um aço elétrico. ... 19 Figura 15: Efeito dos teores de enxofre, nitrogênio e oxigênio sobre as perdas magnéticas a $1,5 \mathrm{~T}$ e $50 \mathrm{~Hz}$.

Figura 16: Efeito do grau de deformação e do tempo de recozimento a $788^{\circ} \mathrm{C}$ sobre o tamanho de grão. 
Figura 17: Gráfico mostrando a evolução do TG com o tempo durante o recozimento em amostras deformadas.

Figura 18: Curva de recristalização de amostras de cobre para diferentes temperaturas de recozimento.

Figura 19: Micrografia de um material com $2 \%$ de deformação submetido a tratamento térmico por 260 minutos à $755^{\circ} \mathrm{C}$.

Figura 20: Evolução da microestrutura de um aço 1006 durante a recristalização.

Figura 21: Curva de recristalização para os aços efervescente e acalmado. 26

Figura 22: Diagrama esquemático mostrando o efeito do número de lados sobre a curvatura do contorno de grão.

Figura 23: Esquema do mecanismo proposto por Hillert mostrando a evolução da estrutura de grãos durante o recozimento... 28

Figura 24: Efeito do ângulo de magnetização com relação à direção de laminação sobre a indução $\mathrm{B}_{50}$ para um aço de $3 \% \mathrm{Si}$. 32

Figura 25: Gráfico obtido por Yensen apud Landgraf onde o comportamento do campo coercivo é dado em função do tamanho de grão. 34

Figura 26: Gráfico de Degauque demonstrando a relação entre campo coercivo e o inverso do tamanho de grão.

Figura 27: Gráfico campo coercivo em função do inverso do tamanho de grão produzido por Battistini para aço inoxidável.

Figura 28: Gráfico campo coercivo em função do inverso do tamanho de grão publicado por Adler e Pfeiffer para amostra de ferro-níquel. 36 Figura 29: Gráfico obtido por Yensen apud Landgraf onde o comportamento da energia dissipada por histerese é dado em função do tamanho de grão. 37 Figura 30: Gráfico de Bertotti relatando as perdas histeréticas em função do inverso da raiz do tamanho de grão. 38 Figura 31: Esboço do núcleo de inversão da magnetização atravessando vários grãos. 39

Figura 32: Perda anômala em função do tamanho de grão. 40 
Figura 33: Perdas anômalas medidas a $50 \mathrm{~Hz}$ para as induções 1 e 1,5T em função do tamanho de grão para amostras de aço não orientado com 1,8\% Si... 41 Figura 34: Evolução das perdas com o tamanho de grão e freqüência de excitação em uma amostra de aço elétrico com $0,5 \%$ de silício.

Figura 35: Evolução das perdas totais com o tamanho de grão para aços elétricos com diferentes teores de silício.

Figura 36: Gráfico das perdas totais $\mathrm{x}$ diâmetro do grão produzido por Shiozaki para amostras de aços de diferentes composições.

Figura 37: Efeito do tamanho de grão nas perdas magnéticas em um aço com $2 \%$ Si.

Figura 38: Esboço de um gráfico mostrando o comportamento das perdas total, anômala e histerética com o aumento do tamanho de grão. 44

Figura 39: Gráfico das perdas em função do tamanho de grão para ensaios realizados nas freqüências $60 \mathrm{~Hz}, 150 \mathrm{~Hz}$ e $400 \mathrm{~Hz}$. 44

Figura 40: Gráfico log (Ph) x log (B) para aço silício. 45

Figura 41: Gráfico log (Ph) x log (B) para as 3 direções de aplicação de campo.. 46 Figura 42: Imagem de uma micrografia contendo a linha teste usada para a medição do tamanho de grão pelo método dos interceptos. 53 Figura 43: Imagem mostrando os contornos reconhecidos automaticamente pelo software Altra System através da ferramenta Separator.

Figura 44: Exemplo de micrografia após aplicação dos filtros Separator e Low Pass.

Figura 45: Exemplo de um quadro de Epstein usado para caracterização magnética.

Figura 46: Gráfico da Deformação real em função do tamanho de grão $(\ell)$ para as amostras submetidas a aumento de tamanho de grãos por recristalização. 58 Figura 47: Curvas de recristalização com os resultados extraídos de Ashbrook e os obtidos no processo de aumento de tamanho de grão por recristalização....... 59 Figura 48: Gráfico $1 / \ell^{3} \mathrm{x}$ deformação para as amostras submetidas a aumento do tamanho de grão por recristalização. 60 
Figura 49: Gráficos com as distribuições de tamanho de grão das amostras submetidas a aumento de tamanho de grão por recristalização.

Figura 50: Gráficos com as distribuições de tamanho de grão das amostras submetidas a aumento de tamanho de grão por crescimento

Figura 51: Micrografia ilustrando a estrutura de grãos em uma amostra recozida a $600^{\circ} \mathrm{C}$ por duas horas. Em destaque, um grão grande contendo 10 lados.

Figura 52: Micrografia de amostra submetida á crescimento de grãos por tratamento térmico a $850^{\circ} \mathrm{C}$ por oito horas. 66

Figura 53: Comparação entre as histereses obtidas no IPT e no Inmetro para indução máxima de 1,5T no regime quase estático para a amostra SEW 540 ....67 Figura 54: Comparação entre as histereses obtidas no IPT e no Inmetro para indução máxima de 1,5T no regime quase estático para a amostra SEW 400 .... 68 Figura 55: Comparação entre as histereses obtidas no IPT e no Inmetro para indução máxima de 1,5T no regime quase estático para a amostra SEW 400....68 Figura 56: Gráfico mostrando o comportamento do campo coercivo Hc em função do inverso do tamanho de grão (1/l). 71

Figura 57: Gráfico do campo coercivo $(\mathrm{Hc})$ em função do inverso da raiz do tamanho de grão.

Figura 58: Gráfico Hc x 1/l onde são mostrados os resultados da caracterização magnética, dados pelas linhas Linear $(B=1 T)$ e Linear $(B=1,5 T)$, e os resultados obtidos por Yensen e Degauque.

Figura 59: Gráfico indicando as retas Hc x 1/l obtida por Yensen, calculada a partir da expressão proposta por Mager e a construída a partir dos resultados experimentais.

Figura 60: Gráfico Hc x 1/l para as induções máximas 0,6, 0,8, 1,0, 1,2, 1,4 e 0,5T medidas em ensaio quase estático.

Figura 61: Linhas de tendência para o gráfico Hc $\times 1 / \ell$ para diversas induções indicando uma dependência linear. 75 Figura 62: Gráfico do coeficiente angular da reta $\mathrm{Hc} \times 1 / \ell$ em função da indução máxima. 
Figura 63: Gráfico do coeficiente linear da reta $\mathrm{Hc} \times 1 / \ell$ em função da indução máxima. .77

Figura 64: Gráfico da energia dissipada na histerese em função do tamanho de grão.

Figura 65: Gráfico Wh x 1/l para as induções máximas de 0,6;0,8;1,0;1,2;1,4 e $1,5 \mathrm{~T}$.

Figura 66: Gráfico do coeficiente angular da curva $\mathrm{Ph} \times 1 / \ell$ em função da indução máxima.

Figura 67: Gráfico do coeficiente linear da reta $\mathrm{Ph} \times 1 / \ell$ em função da indução máxima.

Figura 68: Gráfico Wh x 1/l para diversos valores de indução máxima. Os resultados experimentais são indicados por pontos e as retas foram calculadas através da Equação 18.

Figura 69: Gráfico $\mathrm{Ph} \times 1 / \ell$ comparando retas produzidas nesse trabalho e as produzidas a partir dos resultados de Bertotti. 82

Figura 70: Gráfico das perdas totais em função do tamanho de grão $(\ell)$. 83 Figura 71: Gráfico das perdas parasitas (Pp) em função da espessura das amostras.

Figura 72: Gráfico relacionando as perdas total $(\mathrm{Pt})$, histerética $(\mathrm{Ph})$, parasita $(\mathrm{Pp})$ e anômala $(\mathrm{Pa})$ ao tamanho de grão $\ell$ para indução máxima de 1,0T.

Figura 73: Gráfico relacionando as perdas total $(\mathrm{Pt})$, histerética $(\mathrm{Ph})$, parasita $(\mathrm{Pp})$ e anômala ( $\mathrm{Pa}$ ) ao tamanho de grão $\ell$ para indução máxima de 1,5T.

Figura 74: Gráfico da perda histerética (Wh) em função da indução máxima (B) para amostras com diferentes tamanhos de grão para valores de $B$ entre 0,6 e $1,5 \mathrm{~T}$.

Figura 75: Gráfico Ph x B para o intervalo de induções entre 0,6 e 1,2T. 87

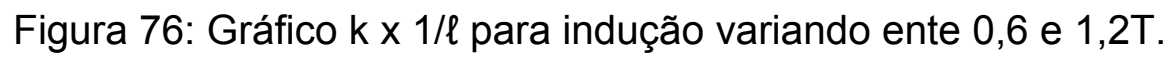
88

Figura 77: Coeficiente de Steinmetz (q) em função do tamanho de grão $(\ell)$ para faixa de induções entre 0,6 e 1,2T. 89 


\section{LISTA DE TABELAS}

Tabela 1: Efeito da quantidade de deformação sobre o tamanho de grão

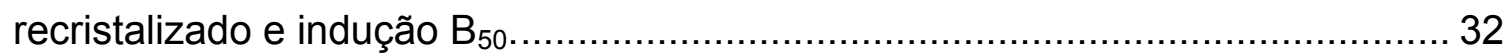

Tabela 2: Tamanho de grão e $B_{50}$ das amostras estudadas por Park e Szpunar. . 33 Tabela 3: Composição química do Coscore U260, conforme reportado pela Cosipa. 48

Tabela 4: Deformação real e espessura dos conjuntos de amostras. 50 Tabela 5: Comparação entre os resultados das medições de tamanho de grão pelos métodos dos interceptos e das áreas. 66 Tabela 6: Valores de campo coercivo e energia dissipada por histerese para as amostras analisadas no Inmetro e no IPT. 69

Tabela 7: $\mathrm{B}_{50}$ da amostra submetida a alívio de tensões ..... 69

Tabela 8: $\mathrm{B}_{50}$ das amostras submetidas a aumento de TG por recristalização..... 69 Tabela 9: $B_{50}$ das amostras submetidas a aumento de $\mathrm{Tg}$ por crescimento de grãos. 70

Tabela 10: Equações das retas e coeficientes de determinação provenientes do ajuste linear dos gráficos $\mathrm{Hc} \times 1 / \ell$ e Hc $\times 1 / \sqrt{ } \ell$ para as induções de 1,0 e 1,5T.....72 Tabela 11: Valores dos coeficientes linear e angular e índice de determinação para $o$ ajuste linear dos gráficos $\mathrm{Hc} \propto 1 / \ell$ e $\mathrm{Hc} \propto 1 / \sqrt{ } \ell$.

Tabela 12: Coeficientes lineares e angulares e índices de determinação para as retas $W h \propto 1 / \ell$ e $W h \propto 1 / \sqrt{ } \ell$ em diversos valores de indução máxima. 79 Tabela 13: Valores do número pré-exponencial $(k)$,do coeficiente exponencial $(q)$ e do índice de determinação $\mathrm{R}^{2}$ para as equações de ajustes que descrevem o efeito da indução máxima sobre a emergia dissipada por histerese para cada uma das amostras. 86

Tabela 14: Valores do coeficiente pré-exponencial $(k)$, coeficiente exponencial $(q)$ e índice de determinação $\left(R^{2}\right)$ para as equações de ajuste que descrevem a curva Wh x Bmax com indução máxima variando entre 0,6 e 1,2T para cada uma das amostras. 


\section{SUMÁRIO}

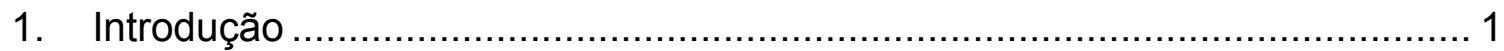

1.1 Classificação e utilização dos aços elétricos ...................................... 2

1.2 O processo de produção dos aços elétricos ...................................... 4

1.3 Conceitos básicos: características e propriedades magnéticas dos materiais ferromagnéticos.................................................................... 6

1.3.1 Ferromagnetismo e permeabilidade magnética ........................... 6

1.3.2 A estrutura de domínios ..................................................... 8

1.3.3 Processo de magnetização e o ciclo de histerese .......................... 10

1.3.4 Mecanismos de dissipação de energia em aplicações em corrente alternada ................................................................................... 14

1.3.5 Separação das perdas magnéticas em parcelas .......................... 14

1.3.6 Relação entre microestrutura e propriedades magnéticas dos aços

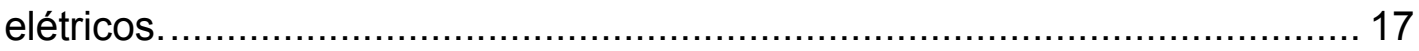

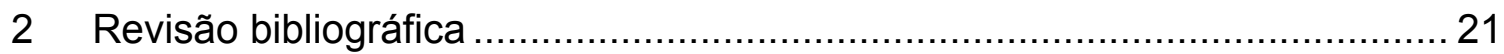

2.1 Sobre o aumento do tamanho de grão …..................................... 21

2.1.1 Aumento do tamanho de grão por deformação e recristalização..... 21

2.1.2 Aumento do tamanho médio de grãos por crescimento normal....... 26

2.1.3 Aumento do tamanho médio de grãos por crescimento anormal..... 29

2.2 Sobre o efeito do tamanho de grão sobre as propriedades magnéticas em aços elétricos ................................................................................ 30

2.2.1 Sobre os métodos de aumento do tamanho de grão e a anisotropia das propriedades magnéticas .......................................................... 31

2.2.2 O efeito do tamanho de grão sobre o campo coercivo. .................. 33

2.2.3 O efeito do tamanho de grão sobre a energia dissipada por

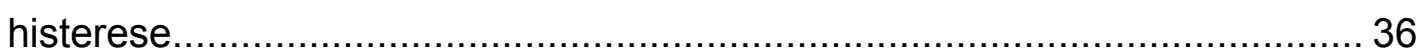

2.2.4 O efeito do tamanho de grão sobre a perda anômala..................... 40

2.2.5 A evolução das perdas totais com o aumento do tamanho de

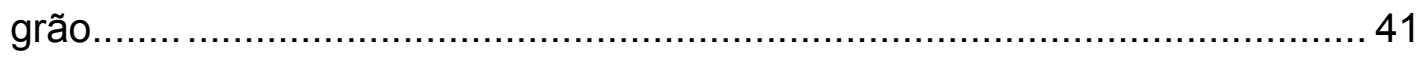


2.2.6 O efeito da indução máxima sobre perda histerética e campo coercivo.

2.2.7 Considerações acerca da relação entre microestrutura e propriedades magnéticas. ..................................................................... 46

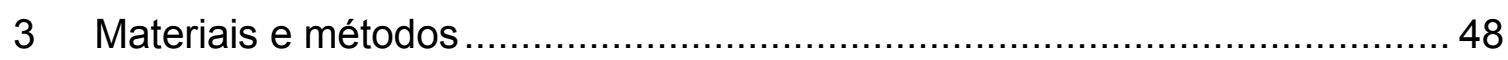

3.1 Obtenção de conjuntos de amostras com diferentes tamanhos de grãos. 48

3.1.1 Aumento do tamanho de grão por recristalização......................... 49

3.1.1.1 - A etapa de laminação .................................................... 49

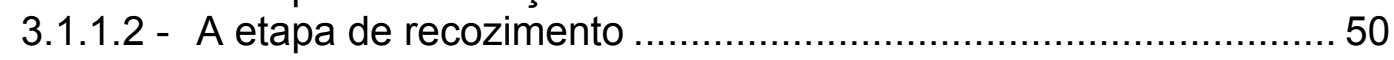

3.1.2 O aumento do tamanho de grão por crescimento........................ 51

3.2 Caracterização microestrutural................................................ 52

3.2.1 Medição do tamanho de grão pelo método dos interceptos ............ 52

3.2.2 Medição do tamanho de grãos pelo método das áreas .................. 53

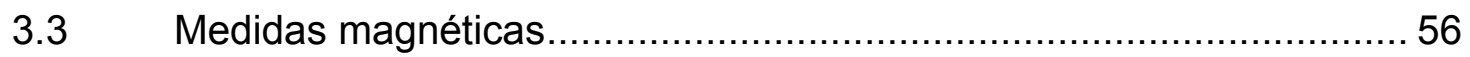

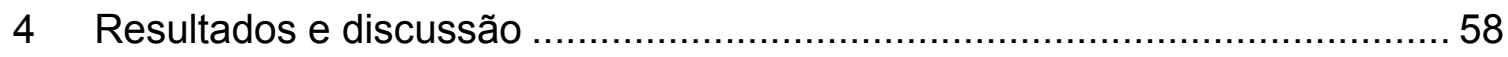

4.1 Sobre o aumento do tamanho de grão..................................... 58

4.1.1 Aumento do tamanho de grão por recristalização.......................... 58

4.1.2 Aumento do tamanho de grão por crescimento ............................63 63

4.2 Comparação entre os resultados de caracterização magnética obtidos

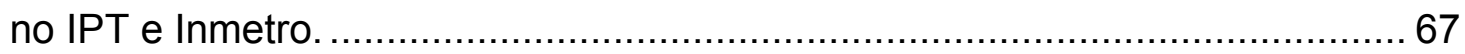

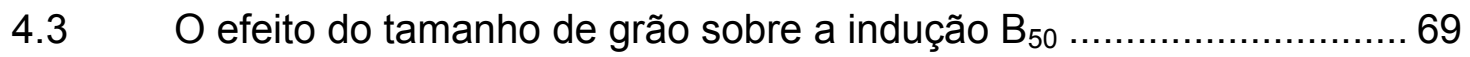

4.4 O efeito do tamanho de grão sobre o campo coercivo ...................... 70

4.5 O efeito do tamanho de grão sobre a energia dissipada por histerese 78

4.6 A relação entre tamanho de grão e perdas totais ............................. 82

4.7 O efeito da indução máxima sobre a energia dissipada por histerese 85

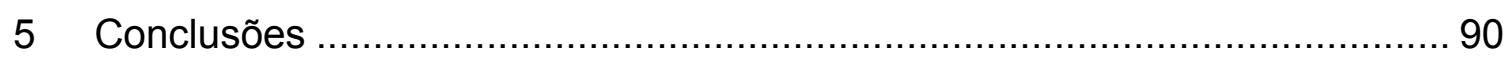

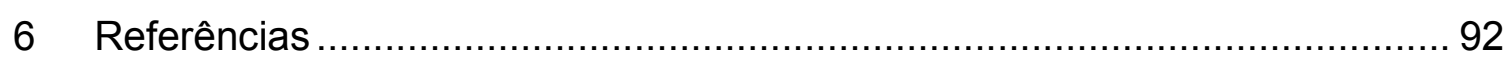

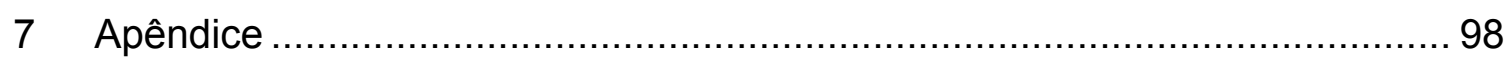

7.1 Histereses das amostras com aumento do tamanho de grão por crescimento. 
7.2 Histerese das amostras com aumento de tamanho de grão por

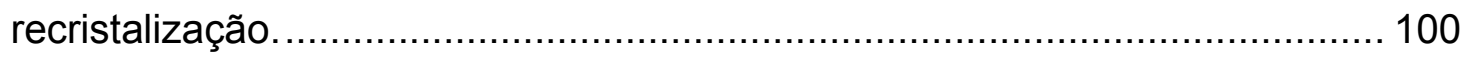




\section{INTRODUÇÃO}

A aplicação de materiais magnéticos é das mais extensas no campo da indústria elétrica [1]. Dentre esses materiais merecem destaque os aços elétricos. Estes aços não são usados na condução de corrente elétrica, mas sim fluxo magnético, que circula no interior do material. Esses materiais são magneticamente moles e sua aplicação se dá na forma de chapas usadas na confecção de dispositivos elétricos, tais como núcleos de transformadores e motores elétricos.

Em aplicações em corrente alternada, parte da energia fornecida pela passagem de corrente elétrica é dissipada no aço durante o seu uso devido a características microestruturais e geométricas (os mecanismos que levam o material a dissipar energia serão vistos em maiores detalhes mais adiante). A energia que esse material dissipa durante o processo de magnetização e desmagnetização recebe o nome de perdas magnéticas ou perdas no ferro.

O rápido aumento da atividade industrial e a crescente demanda por eletricidade trouxeram à tona discussões acerca da questão energética uma vez que os combustíveis fósseis, atualmente a principal fonte de geração de energia, não são inesgotáveis. Uma das soluções apontadas para esse problema contemporâneo é o aumento do rendimento energético de máquinas elétricas. Diante desse fato muitos trabalhos citam as vantagens econômicas e ambientais que o desenvolvimento de aços elétricos de melhor desempenho pode proporcionar. Moses [2], em um trabalho publicado em 1990, cita que $5 \%$ de toda energia gerada era dissipada na forma de perdas magnéticas. Do ponto de vista ambiental o artigo cita ainda que no Reino Unido apenas os transformadores desperdiçavam à época o equivalente à energia produzida com o consumo de 7 milhões de barris de petróleo por ano. A produção dessa quantidade de energia emitiria 35000 toneladas de dióxido de enxofre na atmosfera anualmente.

Outro grande impulso para a produção de melhores aços é a substituição de motores à combustão interna por motores elétricos. Esta possibilidade é de grande interesse dos fabricantes de veículos híbridos. Essa tecnologia permite que motores elétricos possam auxiliar um motor à gasolina fornecendo potência extra 
quando o veículo acelera ou percorre trechos íngremes. Outras vantagens são: a redução do tamanho e aumento da eficiência do motor a explosão.

Aços elétricos são materiais de elevado valor agregado e de grande aplicabilidade. Novas tecnologias e a crescente demanda por eletricidade tendem a elevar a importância dos aços elétricos no cenário mundial. A necessidade de desenvolvimento de máquinas elétricas de alto rendimento impõe como desafio a produção de aços que conciliem baixa dissipação de energia e baixo custo. Pequenos motores de uso doméstico têm menor eficiência energética (aproximadamente 50\%) pois usam aço de menor qualidade em função do baixo custo. Ainda assim é cada vez maior o interesse das siderúrgicas por essa classe de materiais em virtude de sua lucratividade, portanto, faz-se necessário o entendimento dos mecanismos de dissipação de energia desse material para atender à crescente demanda por meIhor desempenho energético.

\subsection{Classificação e utilização dos aços elétricos}

Dentre os materiais magneticamente moles produzidos hoje, o aço elétrico é o mais importante. Seu volume de produção corresponde a $96 \%$ do total produzido em 2006 para essa classe de materiais [3]. A Figura 1 mostra as principais classes de materiais magneticamente moles e sua participação na produção mundial em toneladas por ano. Nesta figura os materiais magneticamente moles estão divididos em três grandes grupos: aços elétricos de grão orientado (GO), aços elétricos de grão não orientado (GNO) e outros. Este último grupo é composto por ferritas, pós, ligas nanocristalinas, ligas amorfas, FeSi 6,5\% e liga FeNi.

Os aços elétricos são classificados de acordo com a intensidade da textura de sua microestrutura. Esse critério nos leva a dividi-los em dois grandes grupos: os aços de grão não orientado e os aços de grão orientado. 


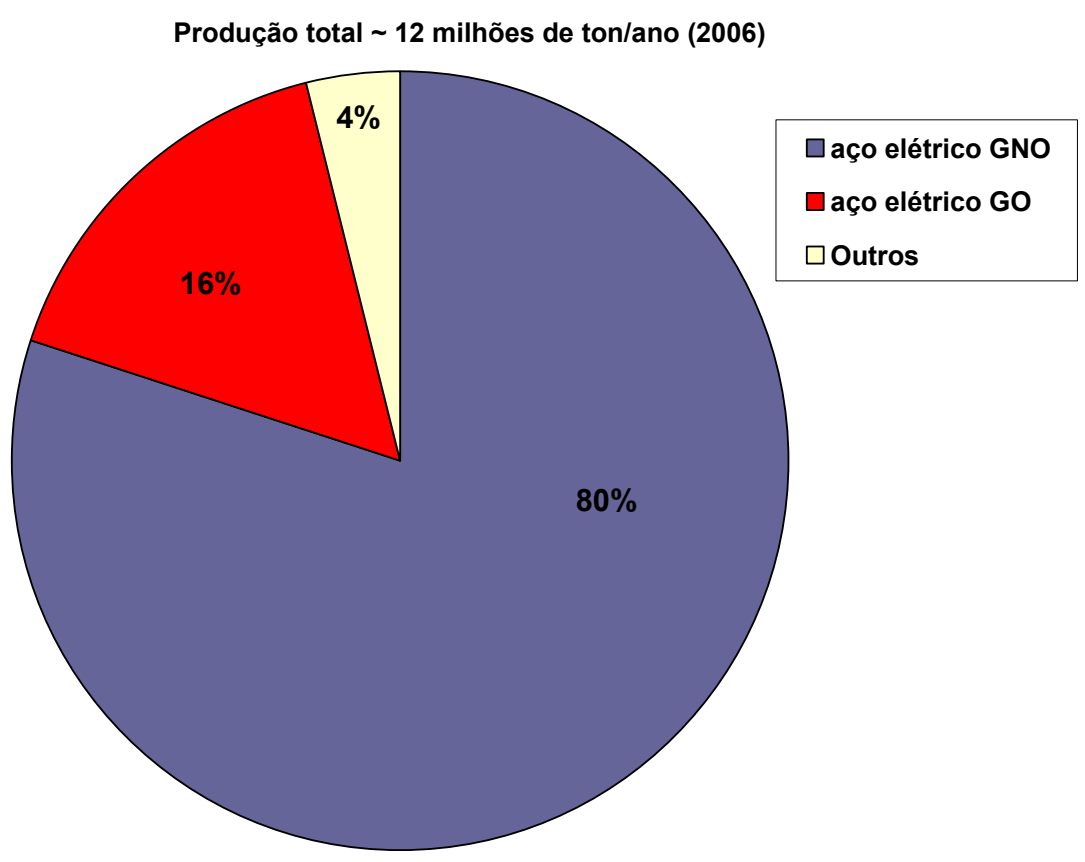

Figura 1: Participação da produção dos diferentes materiais magneticamente moles [3].

Os aços de grão orientado (GO) possuem forte textura cristalográfica onde a grande maioria dos cristais que compõem a chapa tem planos $\{110\}$ paralelos à superfície da mesma, com a direção <001> paralela à sua direção de laminação. Isso confere forte anisotropia ás propriedades magnéticas do material fazendo com que este exiba características ótimas apenas na direção de laminação. É o material mais indicado para a construção de grandes transformadores, onde a chapa é submetida a um campo magnético unidirecional que pode ser alinhado à direção longitudinal da chapa.

Os aços de grão não-orientado (GNO) possuem fraca textura. É desejável que esse aço possua isotropia das propriedades magnéticas no plano da superfície da chapa. Sua aplicação se dá na construção de motores onde o campo magnético aplicado pertence a planos paralelos à superfície da chapa, porém a direção é variada.

São exigidas dos aços GNO resistência mecânica e estampabilidade. Na construção de grandes máquinas e equipamentos de difícil refrigeração uma baixa dissipação de energia é a característica exigida para a seleção do aço. Em pe- 
quenos motores, amplamente usados em aplicações domésticas, por motivos econômicos como citado anteriormente são usados aços de menor eficiência porém de custo mais baixo.

\subsection{O processo de produção dos aços elétricos}

A base do processo de produção de um aço elétrico de grão não-orientado tem início no ligotamento contínuo do aço, silicioso ou não, seguido de laminação a quente onde são produzidas chapas com 2,3mm de espessura. Após essa etapa a espessura da chapa é reduzida à aproximadamente $0,54 \mathrm{~mm}$ através de laminação a frio. Os diferentes processos que se seguem levam à obtenção das diferentes classes de aços GNO. Para a produção do aço elétrico de grão não-orientado totalmente processado a bobina fria (ou seja, o material resultante da laminação a frio) passa por recozimento contínuo a uma temperatura entre 900 e $1100^{\circ} \mathrm{C} \mathrm{em}$ ambiente contendo os gases $\mathrm{N}_{2}, \mathrm{H}_{2}$ e $\mathrm{H}_{2} \mathrm{O}$. Nesta etapa ocorrem recristalização e crescimento de grão e após seu término o material pode ser bobinado e enviado para puncionamento.

A produção de aço GNO semi-processado também parte da bobina fria de aço elétrico com $0,5 \mathrm{~mm}$ de espessura porém, para essa classe de aços GNO, o recozimento contínuo é feito entre 700 e $900^{\circ} \mathrm{C}$ seguida de laminação a frio, chamada de laminação de encruamento. Esse material é entregue ao fabricante de motores que executa o puncionamento das peças e seu recozimento final [4].

Coombs [5], citando Goss [6], descreve o processo de produção de aços elétricos de grão-orientado partindo de uma bobina quente de aço elétrico. $O$ autor adotou a polegada como unidade para descrever espessura, aqui estes valores foram convertidos para micrometros.

A bobina quente, cuidadosamente laminada apartir de um lingote tem teor de silício entre 3 e 3,3\%; manganês entre 0,04 a 0,10\%; 0,03\% de carbono; 0,2\% enxofre e teores de cobre e níquel inferiores a $0,1 \%$. O autor afirma que a temperatura final e taxa de resfriamento a partir dessa bobina é muito importante, uma vez que ela influencia a orientação da textura, estrutura de grãos e distribuição de car- 
betos. A textura da $B Q$ e carbetos então desenvolvidos têm efeito na textura final e conseqüentemente na qualidade do material completamente processado. A metalografia da $B Q$ indica que esta consiste de grão equiaxiais na superfície e grãos grandes e alongados na região central. Em seguida, é feito o corte lateral para que a bobina adquira a largura necessária.

A etapa seguinte consiste no tratamento térmico realizado ao ar em temperaturas na faixa de $820^{\circ} \mathrm{C}$ a $920^{\circ} \mathrm{C}$ em recozimento contínuo. Esse recozimento permite que a textura ideal e microestrutura ideal sejam obtidas. É feita então a limpeza da superfície do material.

Segue, então, a laminação a frio para que a chapa adquira espessura entre $508 \mu \mathrm{m}$ e $711 \mu \mathrm{m}$ variando de acordo com o tratamento. Durante o trabalho a frio é desenvolvida a textura (111) [112]. O desenvolvimento da textura Goss depende dessa formação.

O material passa então por tratamento térmico em forno contínuo em temperatura por volta de 900 a $950^{\circ} \mathrm{C}$ para então sofrer nova laminação até atingir a espessura final que deve ser menor que $381 \mu \mathrm{m}$. Após essa etapa o teor de carbono está entre 0,02 e 0,025\%C. Essa quantidade deve ser reduzida para menos de 0,005\% para a produção de material de boa qualidade. O material é submetido a tratamento térmico descarbonetante entre 800 e $850^{\circ} \mathrm{C}$ em forno contínuo. A atmosfera usada nesse recozimento consiste de uma mistura gasosa de hidrogênio e vapor d'água.

O recozimento a alta temperatura é realizado (entre 1100 e $1200^{\circ} \mathrm{C}$ ) para desenvolver a desejada textura Goss. As fases dispersas (precipitados de sulfeto de manganês) atuam como inibidores do crescimento normal ocasionando recristalização secundária. Os grãos de orientação Goss crescem radialmente consumindo os grãos da matriz. Depois de terminada a recristalização secundária as chapas possuem textura (110)[001]. Para a obtenção do produto final segue-se a formação de um filme de fosfato que atuará como isolante, corte da chapa e tratamento térmico para alívio das tensões introduzidas pelo corte. 


\subsection{Conceitos básicos: características e propriedades magnéticas dos ma- teriais ferromagnéticos}

\subsubsection{Ferromagnetismo e permeabilidade magnética}

Alguns materiais, tal como o ferro, são marcadamente magnéticos, enquanto que outros não o são. A importância histórica e comercial do ferro como um material magnético deu origem ao termo ferromagnetismo para agrupar materiais com propriedades magnéticas semelhantes às exibidas pelo ferro. Esta é a mais importante classe de materiais magnéticos.

O ferromagnetismo é resultado da estrutura eletrônica dos átomos. No máximo dois elétrons podem ocupar cada um dos níveis de energia de um átomo. Esses dois elétrons têm spins opostos e cada elétron, ao girar em torno de si mesmo atua como um magneto extremamente pequeno, com os correspondentes pólos norte e sul. Elementos com subníveis internos não totalmente preenchidos têm o número de elétrons com spin num sentido diferente do número de elétrons com spin contrário. Dessa forma esses átomos têm um momento magnético permanente não-nulo. Pode-se definir então uma nova grandeza, chamada magnetização $(M)$, que corresponde ao momento magnético $(\mathrm{m})$ por unidade de volume (V) de um sólido e é matematicamente descrito pela Equação 1.

$$
M=\frac{m}{V} \quad \text { Equação } 1
$$

A Figura 2 traz uma representação do equilíbrio entre os spins eletrônicos de um átomo para um material diamagnético (a), onde para cada elétron com determinado sentido de rotação há um elétron correspondente com spin oposto, e também para um material ferromagnético (b), onde cada átomo apresenta desequilíbrio entre os spins eletrônicos. 


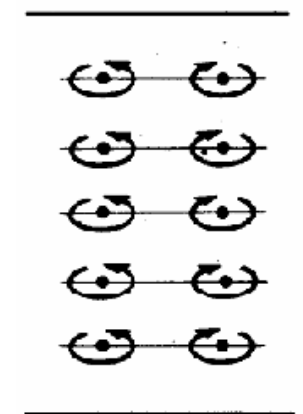

(a)

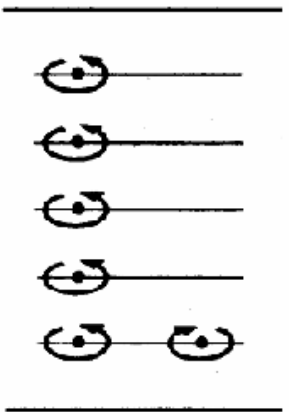

(b)

Figura 2: Representação dos spins eletrônicos na camada 3d para um átomo de um elemento diamagnético (a) e um ferromagnético (b).

A resposta de um material à aplicação de um campo magnético (indução magnética) é dada pela contribuição do campo magnético e da magnetização conforme previsto pela Equação 2, onde $\mu_{0}$ representa a permeabilidade magnética no vácuo e seu valor corresponde a $4 \cdot \pi \cdot 10^{-7} \mathrm{H} / \mathrm{m}$.

$$
B=\mu_{0}(H+M) \text { Equação } 2
$$

O produto entre a permeabilidade magnética no vácuo e a magnetização define a polarização magnética $(\mathrm{J})$ conforme mostra a Equação 3.

$$
J=\mu_{0} \times M \quad \text { Equação } 3
$$

A grande aplicabilidade dos materiais ferromagnéticos se deve à sua capacidade de proporcionar altas induções com a aplicação de campos magnéticos modestos. Dessa forma eles atuam como fonte de campo para a geração de torque sobre um dipolo magnético [7]. A permeabilidade desses materiais é dada pela Equação 4 descrita abaixo. 


$$
\mu_{r}=\frac{B}{\mu_{0} \cdot H} \quad \text { Equação } 4
$$

A permeabilidade relativa (chamada de $\mu_{\mathrm{r}}$ ) de um ferromagnético não é uma função constante com o campo conforme pode ser notado através da curva de magnetização, ou seja, pelo gráfico da indução (B) em função do campo magnético $(\mathrm{H})$ representado na Figura 3.

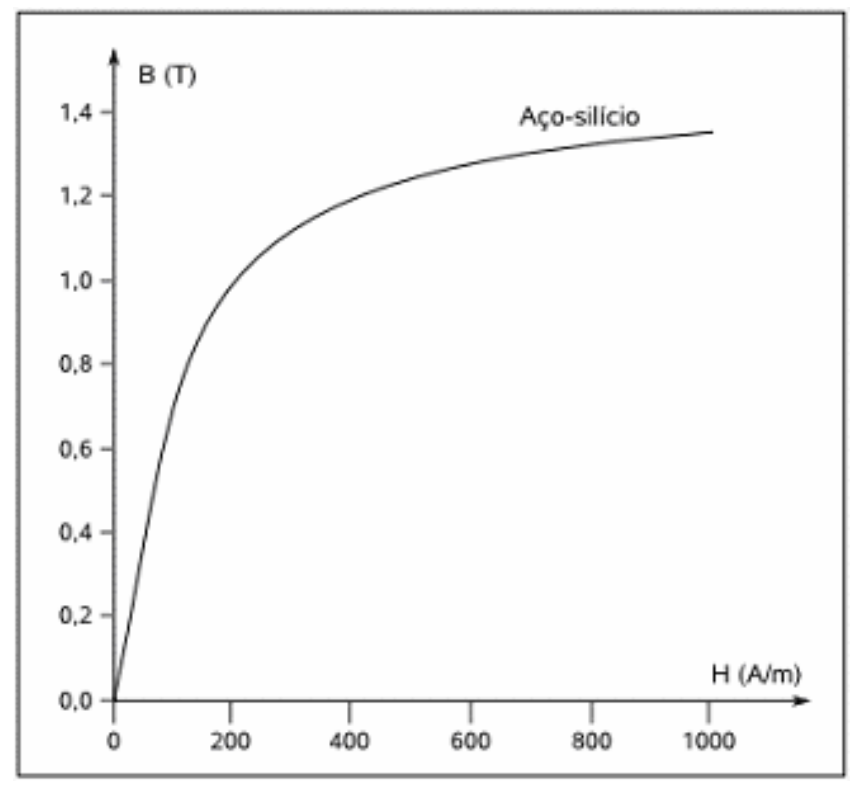

Figura 3: Exemplo de curva de magnetização de um material ferromagnético [8].

\subsubsection{A estrutura de domínios}

Domínios magnéticos são pequenos volumes do material (que podem chegar a $1 \mathrm{~mm}^{3}$ ) onde os momentos magnéticos atômicos estão perfeitamente alinhados. Em um material magnético desmagnetizado os domínios estão orientados ao em várias direções de tal forma que seus efeitos se cancelam conforma descrito pela Figura 4. 


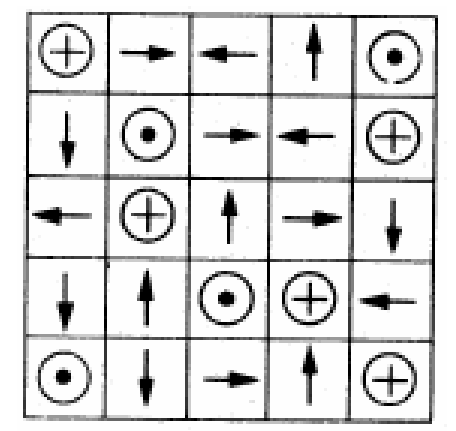

Figura 4: llustração da estrutura de domínios magnéticos em um material desmagnetizado [9].

Conforme dito anteriormente, no interior dos domínios os dipolos estão alinhados paralelamente uns aos outros. Além disso, eles também estão alinhados a direções específicas da rede cristalina, os chamados eixos de fácil magnetização. Essa configuração visa reduzir a denominada energia de anisotropia magnetocristalina. No caso do ferro as direções da família $<100>$ são as de fácil magnetização, já para o níquel os dipolos se alinham nas direções $<111>$.

Em um material cúbico, como o ferro, a energia de anisotropia $\left(E_{a}\right)$ pode ser matematicamente representada de acordo com a Equação 5 [7].

$$
E_{a}=K_{1} \times\left(\cos ^{2} \theta_{1} \cdot \cos ^{2} \theta_{2}+\cos ^{2} \theta_{2} \cdot \cos ^{2} \theta_{3}+\cos ^{2} \theta_{3} \cdot \cos ^{2} \theta_{1}+\right) \text { Equação } 5
$$

onde $\theta_{1}, \theta_{2}$ e $\theta_{3}$ são os ângulos formados pela magnetização em relação a três eixos cristalinos e $\mathrm{K}_{1}$ é uma constante de anisotropia que para o ferro puro vale $48000 \mathrm{~J} / \mathrm{m}^{3}$.

Domínios adjacentes são separados por um contorno denominado parede de domínio. Nestes contornos, os momentos não estão alinhados. Eles apresentam uma mudança gradual de direção de tal forma a promover a transição de orientação dos dipolos atômicos entre os domínios vizinhos conforme ilustrado na Figura 5. 


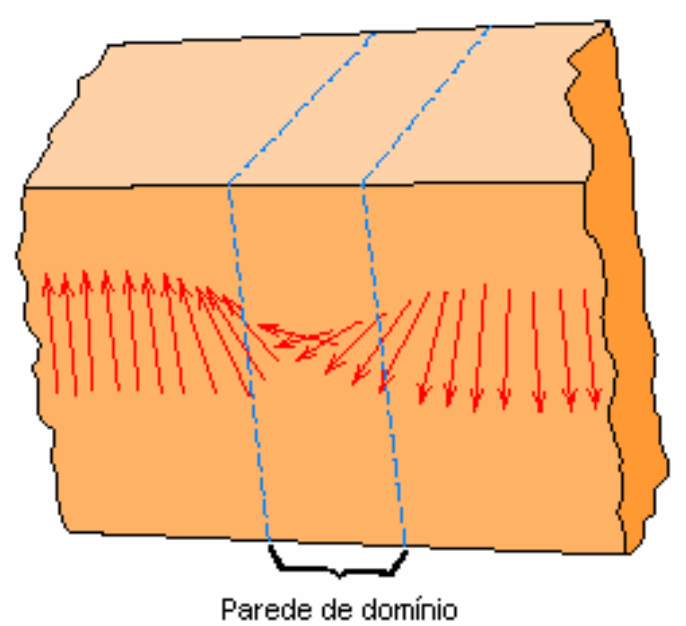

Figura 5: Mudança gradual na orientação dos dipolos através da parede de domínio [10].

\subsubsection{Processo de magnetização e o ciclo de histerese}

O processo de magnetização consiste no alinhamento dos dipolos magnéticos com relação a um campo externamente aplicado. À ação do campo externamente aplicado está associada à energia magnetostática, energia que força o alinhamento dos dipolos magnéticos na direção do campo. A energia magnetostática $\left(E_{m}\right)$ é descrita pelo produto vetorial entre a magnetização e o campo externo (Equação 6).

$$
E_{m}=-\mu_{0} \cdot M \cdot H \cdot \cos \theta \quad \text { Equação } 6
$$

Podemos dividir esse processo em duas etapas: no primeiro há a movimentação das paredes de domínio. Na primeira etapa, a aplicação de campo de baixa intensidade provoca aumento da energia magnetostática. Para a minimização dessa energia ocorre com a diminuição dos domínios cuja direção de magnetização é mais desfavorável. Conseqüentemente há aumento dos domínios com direção de magnetização mais próxima da direção do campo aplicado. Com a elevação da intensidade do campo a movimentação da parede segue até o estado de monodomínio. Até então os dipolos permanecem orientados em direção próxima a dos eixos de fácil magnetização. 
Elevando-se a intensidade do campo externo, ao término da movimentação das paredes, ocorre a rotação dos dipolos que se aproximam da direção do campo. Essa rotação ocorre porque a elevação do campo elevou a energia magnetostática de tal forma que para minimizá-la os dipolos têm de sair dos eixos de fácil magnetização. Assim, a energia total dada pela contribuição dessas duas parcelas (as energias magnetostática e de anisotropia magnetocristalina) torna-se a mínima possível. Ao término da etapa de rotação caracteriza-se o estado de saturação magnética, ou seja, a magnetização $\mathrm{M}$ atingiu o maior valor possível.

Em materiais policristalinos alguns grãos podem estar orientados de forma que uma de suas direções <100> (eixo de fácil magnetização) esteja paralela à direção do campo externamente aplicado. Neste caso apenas os grãos cuja orientação é tal que as direções de fácil magnetização estejam desalinhadas com o campo passarão pela etapa de rotação de domínios. A Figura 6 ilustra a evolução da configuração da estrutura de domínios no decorres do processo de magnetização.

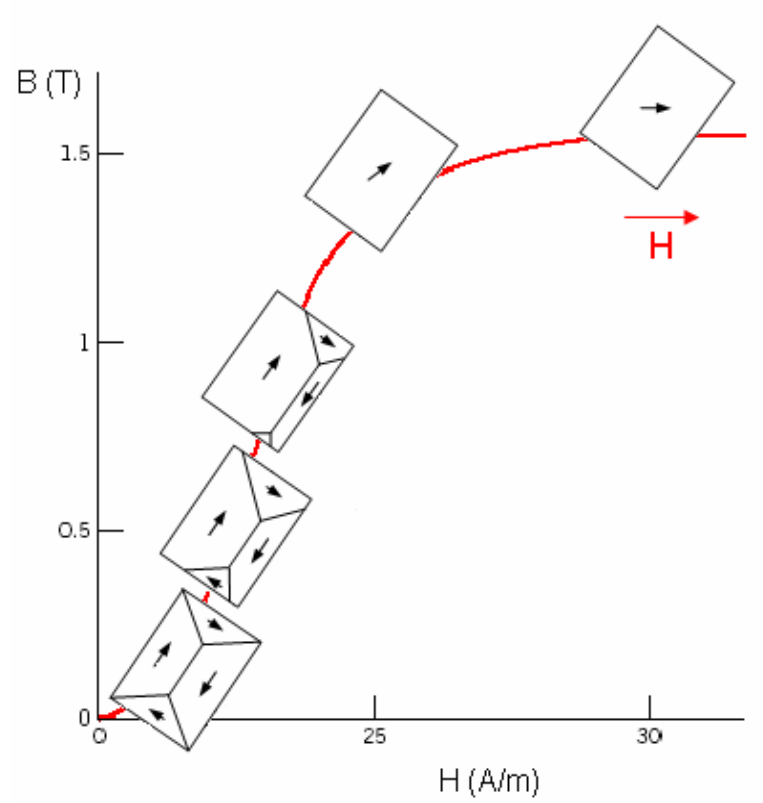

Figura 6: Configuração da estrutura de domínios no decorrer do processo de magnetização (adaptado de [10]). 
Como conseqüência da existência de eixos de fácil magnetização, a curva de magnetização em monocristais pode apresentar diferenças de comportamento conforme a direção do campo externamente aplicado. A Figura 7 traz uma comparação entre as curvas de magnetização para campo aplicado nas direções [100], [110] e [111] em um monocristal de ferro.

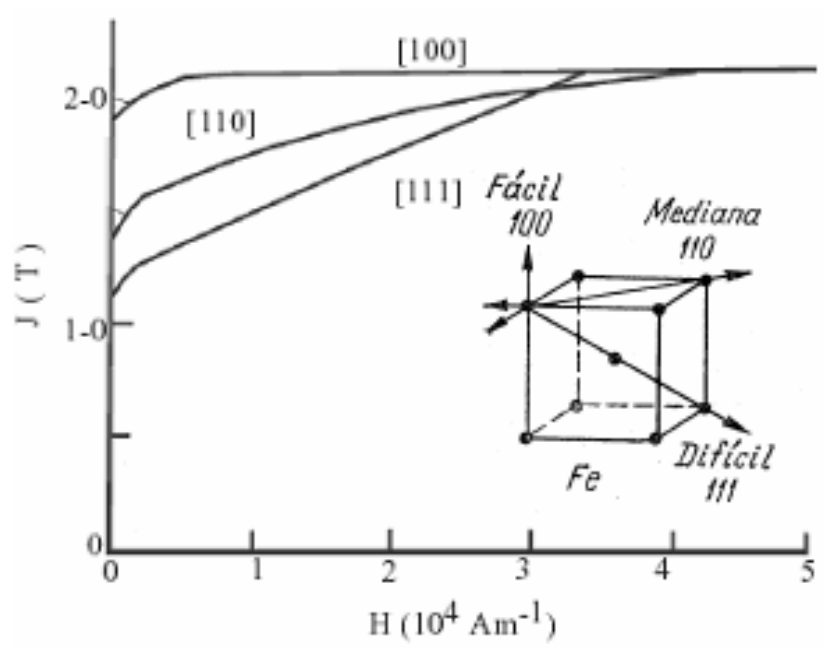

Figura 7: Curva de magnetização com o campo magnético aplicado em três direções cristalinas distintas de um monocristal [11].

O ciclo de histerese é a ferramenta mais comum para a extração de dados acerca das propriedades magnéticas de um material. Este ciclo consiste em um gráfico onde é mostrada a indução, ou polarização magnética (J), em função de um campo $(\mathrm{H})$ para uma amostra submetida a um campo cuja intensidade e sentido de aplicação variam de maneira cíclica. A Figura 8 mostra um ciclo de histerese e seus principais pontos. 


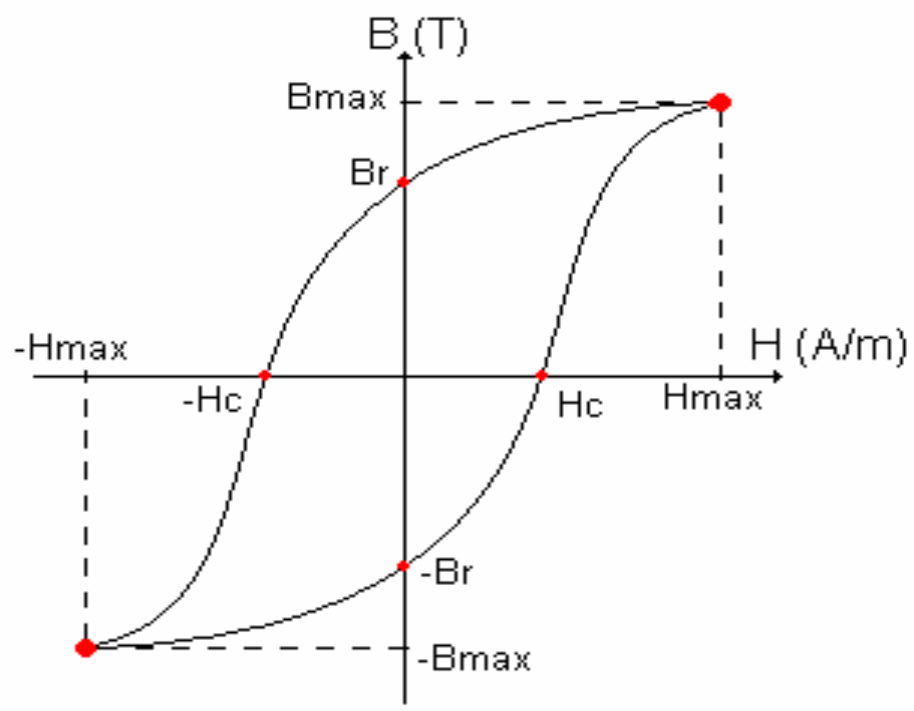

Figura 8: Ciclo de histerese magnética e seus principais pontos [12].

Partindo-se de um material magnetizado, quando o campo é reduzido a zero a indução remanescente é chamada de indução remanente que aparece na Figura 8 indicado por $\mathbf{B r}$ e - $\mathbf{B r}$. Há distinção entre os termos remanência e indução remanente. O primeiro termo é usado para a indução remanescente em um material, anteriormente magnetizado até a saturação, após a retirada do campo. Já o nome indução remanente é dado ao valor de indução que permanece no material, anteriormente magnetizado até um nível arbitrário, após a retirada do campo magnético.

O campo coercivo (Hc e -Hc) é o campo reverso necessário reduzir a indução magnética de um material à zero. Portanto pode-se dizer que campo coercivo é o campo necessário para desmagnetizar o material.

A indução máxima Bmax é um valor arbitrário de indução determinado pela Equação 2, onde o campo aplicado tem intensidade Hmax se o material não estiver magneticamente saturado. Caso a intensidade do campo seja suficientemente alta para alinhar todos os dipolos em sua direção o material entra em estado de saturação magnética. Uma vez saturado magneticamente elevações na intensidade do campo não mais resultarão em aumento no valor de indução. 


\subsubsection{Mecanismos de dissipação de energia em aplicações em corrente al- ternada}

Sobre os materiais ferromagnéticos usados em aplicações em corrente alternada (como no caso dos motores elétricos), pode-se dizer que a propriedade de maior interesse tecnológico é a dissipação de energia ocorrida no processo de magnetização e desmagnetização do material. A energia gasta nesse processo recebe o nome de perda magnética ou perda no ferro e se deve à circulação de correntes parasitas produzidas pela variação com o tempo do fluxo magnético no material e ao fato de a magnetização não ser um processo perfeitamente reversível.

Movimentos irreversíveis de paredes de domínio, bem como rotação irreversível dos domínios durante o processo de magnetização implicam dissipação de energia. Movimentação abrupta de paredes leva á geração de microcorrentes e também ocasionam gasto de energia. Defeitos cristalinos e partículas de segunda fase provocam o ancoramento das paredes. Quando submetidos à aplicação de um campo externo crescente o movimento de paredes pode ser impedido por esses sítios de ancoramento mesmo diante do aumento da energia magnetostática. Se o campo atingir um valor elevado o bastante a parede se desprenderá do defeito se movendo abruptamente provocando variação brusca na direção da magnetização local gerando dissipação de energia. As chamadas perdas parasitas clássicas são causadas por aquecimento por efeito Joule. Essas correntes são induzidas pela variação da indução magnética no corpo do material.

\subsubsection{Separação das perdas magnéticas em parcelas}

As perdas magnéticas podem ser separadas em três parcelas: perdas histeréticas, perdas parasíticas e as perdas anômalas. As perdas anômalas são dadas pela diferença entre as perdas totais e a soma das perdas histeréticas e parasíticas clássicas. A soma dessas três parcelas é denominada perda total. 
As perdas parasitas são ocasionadas por correntes parasitas clássicas que são induzidas no corpo do material. A Figura 9 representa a secção transversal de um material magnético qualquer sendo atravessado por linhas indução estabelecidas no material.

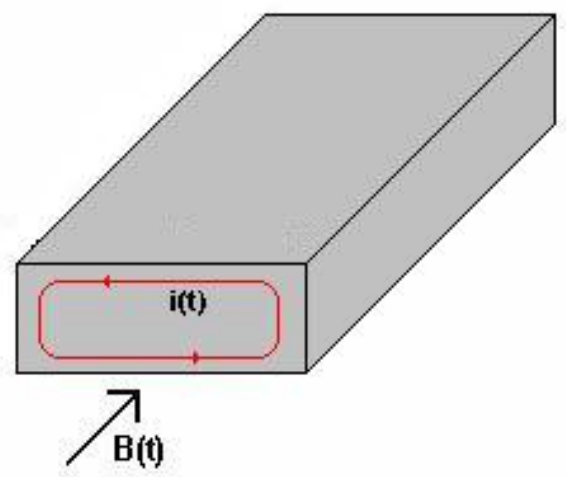

Figura 9: llustração mostrando correntes induzidas $\mathrm{i}(\mathrm{t})$ (correntes parasitas) por uma indução magnética $B(t)$ que varia com o tempo [13].

As correntes parasitas induzidas possuem a liberdade de circular pelo interior do material, sedo limitada apenas pela resistência elétrica do material magnético. Para atenuar os efeitos das correntes parasitas busca-se restringir o valor das correntes induzidas no aço. O valor da parcela parasita $(\mathrm{Pp})$ das perdas é rapidamente calculado através da Equação 7

$$
P_{p}=\frac{(\pi \times B \times f \times e)^{2}}{6 \times d \times \rho} \quad \text { Equação } 7
$$

onde $\mathrm{B}$ é a indução máxima, $f$ é a freqüência de excitação, $e$ corresponde à espessura da chapa, $d$ é a densidade do material e $\rho$ é a resistividade elétrica.

Uma forma de diminuir essa parcela da perda de energia é a diminuição do valor da corrente elétrica através da diminuição do comprimento dos circuitos fechados onde se induz a corrente parasita. Isso é feito através divisão da área secção transversal em pequenas áreas, por utilização de empacotamento de material 
laminado de pequena espessura conforme indica a Figura 10. O valor da corrente elétrica também é diminuído, através da resistividade do material, o que se consegue com a adição pequena quantidade de silício ao ferro em fusão. $O$ efeito do teor de silício sobre a resistividade dos aços para fins elétricos será discutido em maiores detalhes mais adiante.

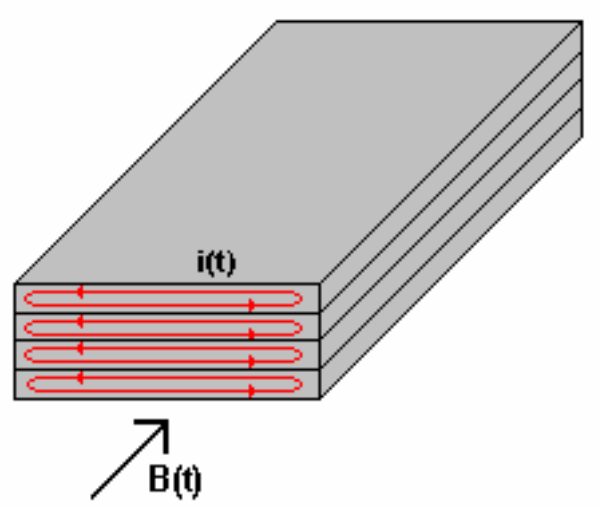

Figura 10: llustração do empacotamento de chapas de pequena espessura para a redução da perda por corrente parasita clássica [13].

Conforme indica a Figura 11 as perdas totais são dependentes da freqüência de excitação, porém mesmo com a extrapolação desse gráfico para freqüência igual a zero o material apresenta considerável perda energética. Essa energia dissipada em regime quase-estático é chamada de perda histerética. Essa parcela das perdas é influenciada por características microestruturais e está associada às mudanças bruscas da magnetização provocadas pelo rápido movimento de paredes que se desprendem dos sítios de ancoramento. 


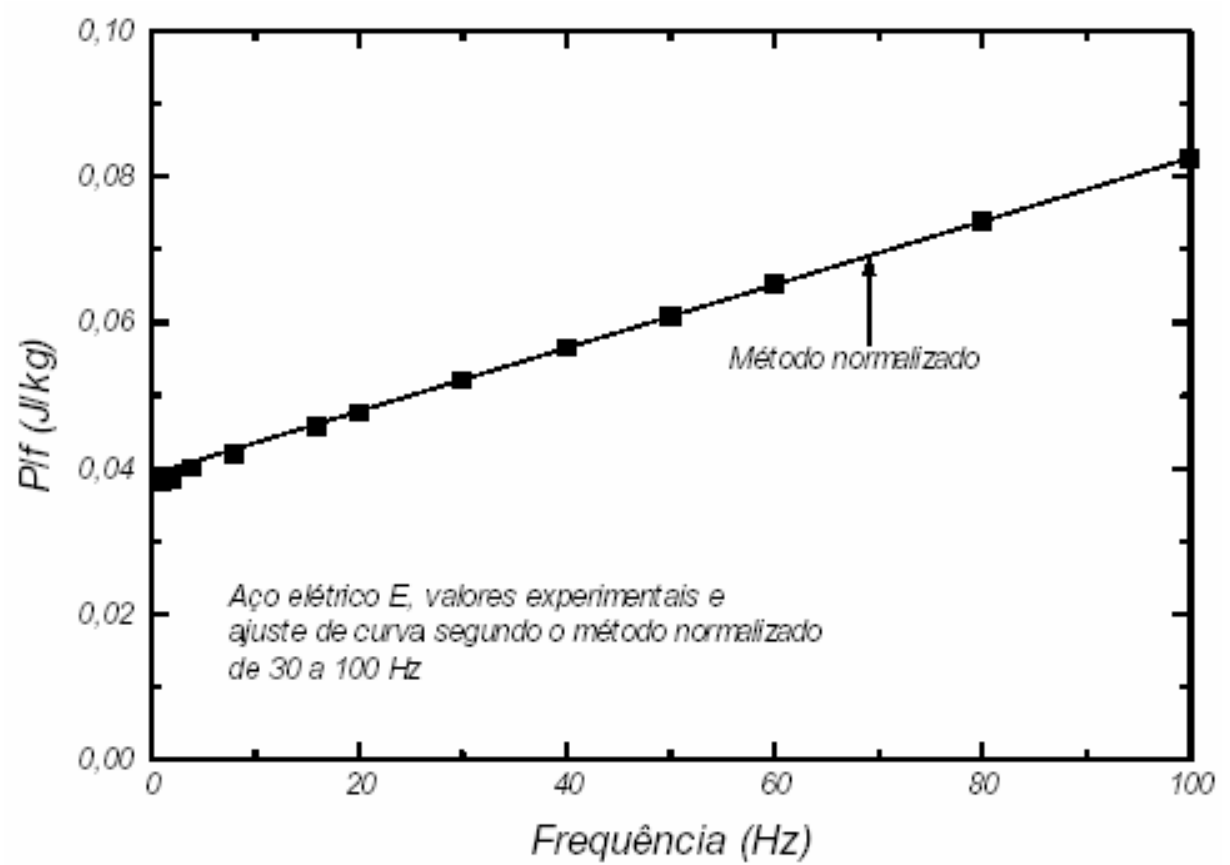

Figura 11: Gráfico ilustrando o comportamento da dissipação de energia em função da freqüência [14].

A soma das parcelas parasita, calculada apartir da Equação 7, e histerética das perdas magnéticas não atingem o valor das perdas totais. Esse complemento é fornecido pelas perdas anômalas, $\mathrm{P}_{\mathrm{a}}$ (ou de excesso) que é calculada pela aplicação da Equação 8.

$$
P_{a}=P_{t}-\left(P_{h}+P_{p}\right) \quad \text { Equação 8 }
$$

\subsubsection{Relação entre microestrutura e propriedades magnéticas dos aços elé- tricos}

Nesta seção serão abordadas algumas características microestruturais que influenciam diretamente as propriedades magnéticas dos aços elétricos sobretudo as perdas magnéticas.

Com relação aos aços elétricos é a composição química do aço quem determina a resistividade elétrica do material. Portanto, a minimização das correntes parasitas clássicas é realizada através da adição alguns elementos que visam ele- 
var a resistividade do material reduzindo as correntes de Foucault induzidas pela variação de indução típicas das aplicações em corrente alternada

Dentre os elementos de liga adicionados aos aços elétricos o silício é o mais importante. Trabalho publicado por Chun-Kan Hou [15] traz uma série de resultados experimentais acerca da influência do teor de silício sobre as perdas magnéticas em aços elétricos com teores de silício variando entre 0,21 e 2,0p\%. Dentre os resultados experimentais desse trabalho está o gráfico da Figura 12 que demonstra um incremento linear da resistividade elétrica com o aumento do teor de silício.

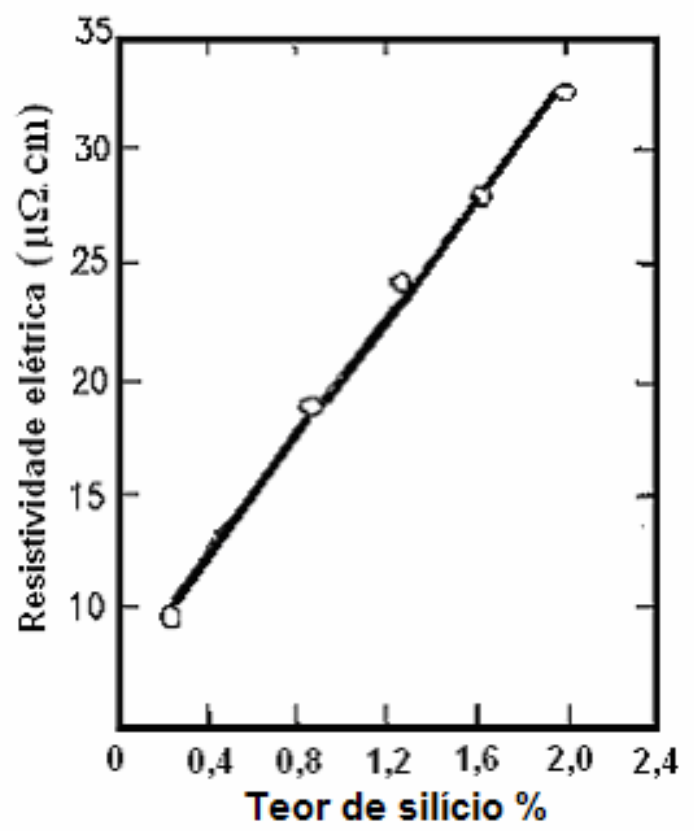

Figura 12: Gráfico da resistividade elétrica em função do teor de silício para aços elétricos [15].

Sobre a influência do teor de silício nas propriedades magnéticas do material, ainda nesse mesmo artigo resultados relacionam a porcentagem de silício às perdas totais medidas a $50 \mathrm{~Hz}$ a induções máximas de 1,0 e 1,5T (Figura 13). Efeito adicional da adição de silício é a redução da anisotropia das propriedades magnéticas. A adição de $3 \%$ de silício reduz a constante de anisotropia magnetocristalina de 48000 para $35000 \mathrm{~J} / \mathrm{m}^{3}$. 


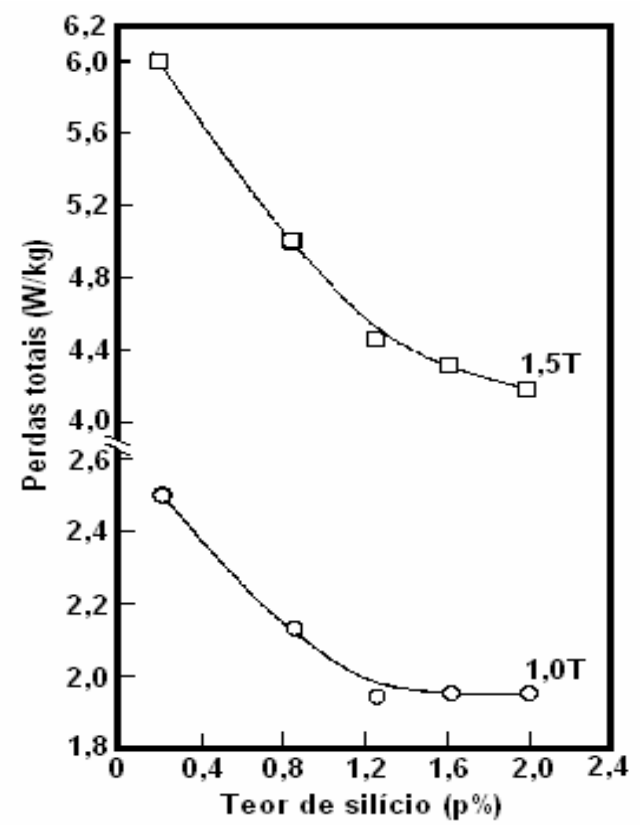

Figura 13: Gráfico das perdas totais a $50 \mathrm{~Hz}$ em função do teor de silício para 1 e 1,5T [15].

Outro elemento adicionado ao aço para promover elevação da resistividade elétrica é o alumínio. O gráfico da Figura 14 foi construído apartir de dados publicados por Hou [16] onde foram analisados aços elétricos com teores de alumínio variando entre 0,022 e $0,32 p \%$.

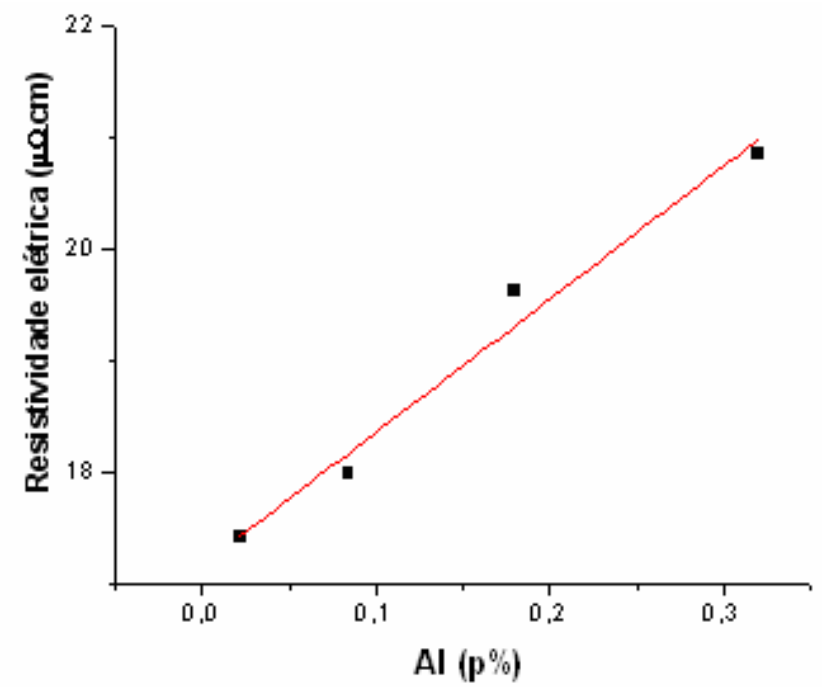

Figura 14: Efeito do teor de alumínio sobre a resistividade de um aço elétrico [16]. 
Dificuldades operacionais causam sensível aumento nos custos para adição de silício e alumínio acima de $1 \%$. Outro fator que determina a importância do controle da composição para definir a qualidade dessa classe de aços é evitar a formação de precipitados. A presença de partículas de segunda fase tem caráter deletério sobre as propriedades magnéticas elevando as perdas histeréticas. Essas partículas atuam como sítios de ancoramento impedindo a movimentação das paredes de domínio durante o processo de magnetização.

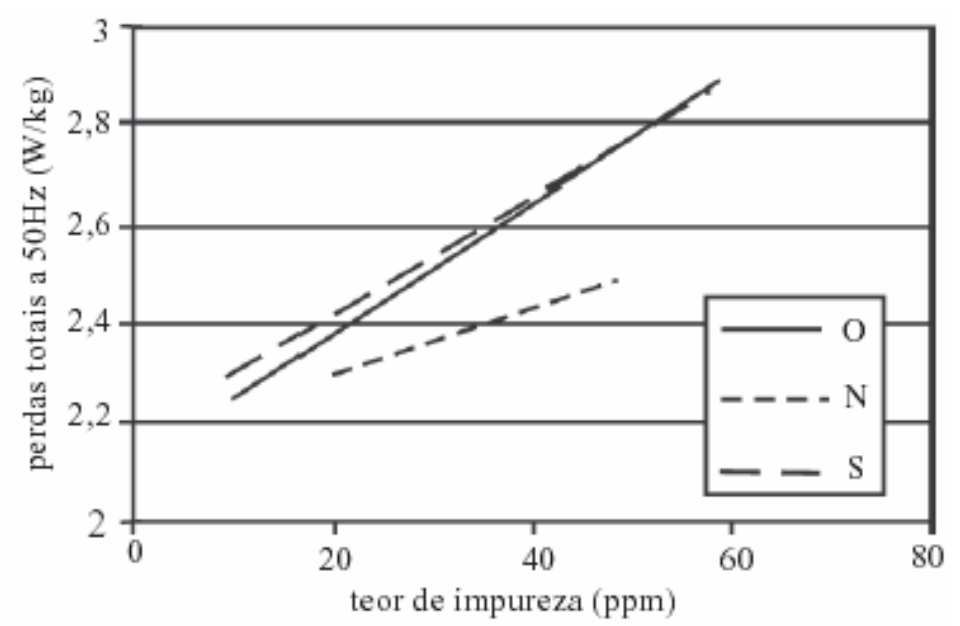

Figura 15: Efeito dos teores de enxofre, nitrogênio e oxigênio sobre as perdas magnéticas a 1,5T e $50 \mathrm{~Hz}[11]$.

As propriedades magnéticas são sensíveis á textura cristalográfica. Conforme citado anteriormente, esse parâmetro é usado para definir as duas grandes classes de aços elétricos. Para os aços de grão não-orientado há uma textura ideal dada pela orientação (100)[0vw] almejada pelos fabricantes desses aços. No entanto, até o presente momento não foi descoberto um processo para a obtenção de um material cujos grãos sigam preferencialmente essa orientação. Esse assunto será novamente abordado posteriormente. 


\section{REVISÃO BIBLIOGRÁFICA}

Nesta seção serão discutidos alguns trabalhos presentes na literatura relacionados ao problema do comportamento do campo coercivo e das perdas magnéticas com relação ao tamanho de grão. Serão abordados também alguns trabalhos relacionados ao aumento de tamanho de grão, etapa fundamental do procedimento experimental desta pesquisa.

\subsection{Sobre o aumento do tamanho de grão}

\subsubsection{Aumento do tamanho de grão por deformação e recristalização}

Executando-se deformação plástica de pequeno grau seguida de tratamento térmico é possível obter grande aumento do tamanho de grão médio de um metal. Esse fenômeno onde, pela aplicação de tratamento térmico, ocorre a mudança da estrutura de grãos de um material deformado plasticamente provocado pela migração de contornos de alto ângulo é chamado de recristalização. A migração dos contornos de alto ângulo avançando sobre a matriz deformada resulta na eliminação das discordâncias introduzidas pela deformação plástica [17]. De fato, o driving force para o processo de recristalização é a energia armazenada no material durante processo de deformação através do aumento da densidade de defeitos cristalinos.

O tamanho de grão alcançado ao final da recristalização é controlado pelo grau de deformação conforme indicam os resultados obtidos por Ashbrook [18], também citados por Landgraf [19] (Figura 16). Pelo gráfico pode-se notar que pequenos graus de deformação resultam em maior tamanho de grão, porém a recristalização necessita de mais tempo para ocorrer. 


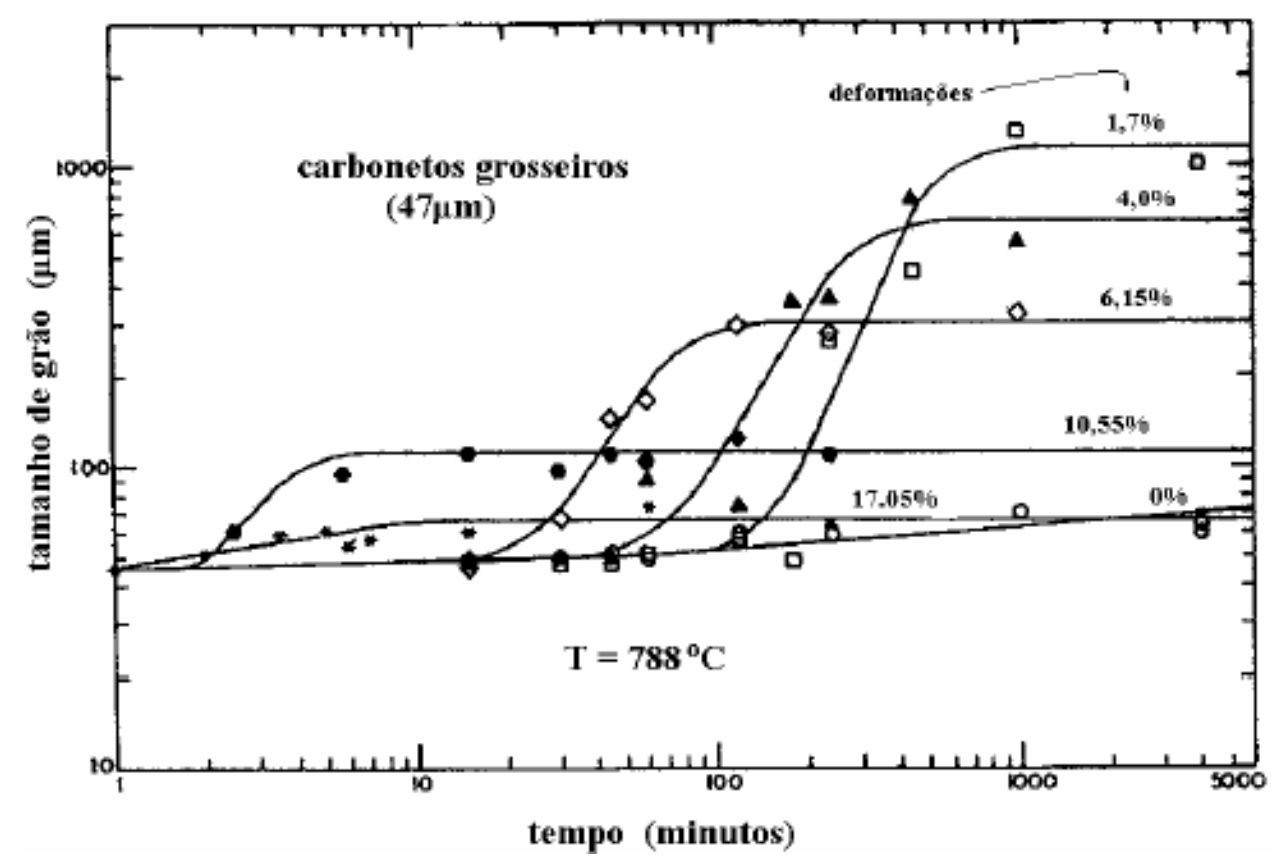

Figura 16: Efeito do grau de deformação e do tempo de recozimento a $788^{\circ} \mathrm{C}$ sobre o tamanho de grão [18].

O mesmo comportamento para o tamanho de grão foi observado por Antonione [20]. Ele descreve o processo do aumento de tamanho de grão por recristalização como apresentando um estágio inicial, onde o crescimento é inibido, seguido por um período de rápido crescimento dos grãos. Tal descrição está de acordo com a figura de Ashbrook. Figura semelhante (Figura 17) foi apresentada

por

Riontino [21] também para descrever a evolução do tamanho de grãos durante o recozimento em amostras submetidas a diferentes graus de deformação. Novamente o período de inibição de crescimento foi observado bem com foi visto que a duração desse período é maior para menores deformações.

Tanto Antonione [20] quanto Riontino [21] atribuem à presença de uma estrutura poligonizada a ação retardadora do crescimento responsável pela existência do período de inibição do crescimento de grãos no início do recozimento. Rios et al. [22] comenta que o período de incubação está geralmente associado com a formação dos núcleos e que a ausência desse período é relacionada a uma nucleação do tipo migração de contornos pré-existentes. 


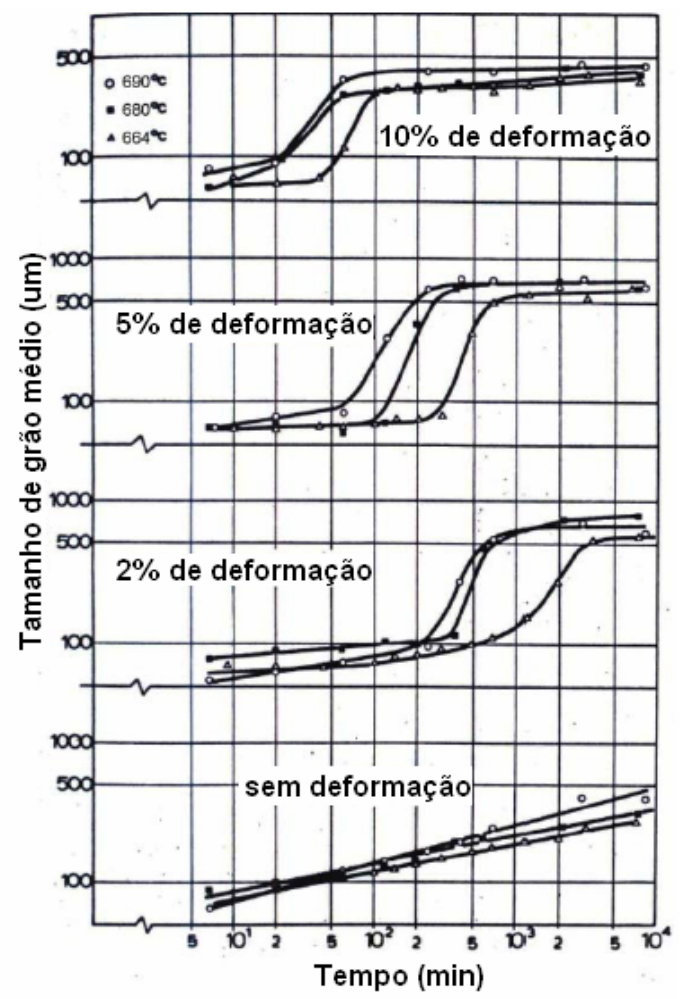

Figura 17: Gráfico mostrando a evolução do TG com o tempo durante o recozimento em amostras deformadas [21].

O tamanho de grão ao término da recristalização não é afetado pela temperatura na qual é conduzido o tratamento térmico. Essa temperatura tem efeito apenas sobre o tempo necessário para que o material deformado sofra completa recristalização. Em seu livro, Reed-Hill [23] cita uma figura (Figura 18) apresentada por Eastwood et al. [24] que relata o tamanho de grão recristalizado em função da quantidade de deformação para diferentes valores de temperatura. Esses resultados foram obtidos em amostras de cobre. Os pontos experimentais comprovam a independência do tamanho de grão recristalizado com relação à temperatura. Vale notar que na figura é estabelecido uma quantidade crítica de trabalho a frio abaixo da qual o período de incubação é demasiado alto.

Segundo Rios et al. [22], o início da recristalização ocorre com a nucleação. Nessa etapa há a formação de regiões de baixa densidade de discordâncias associadas com contornos de alto ângulo. Esses contornos, dotados de alta mobilidade, são capazes de migrar rapidamente pela matriz não recristalizada. O tamanho de grão obtido ao término da recristalização está associado à densidade de núcleos de recristalização. 


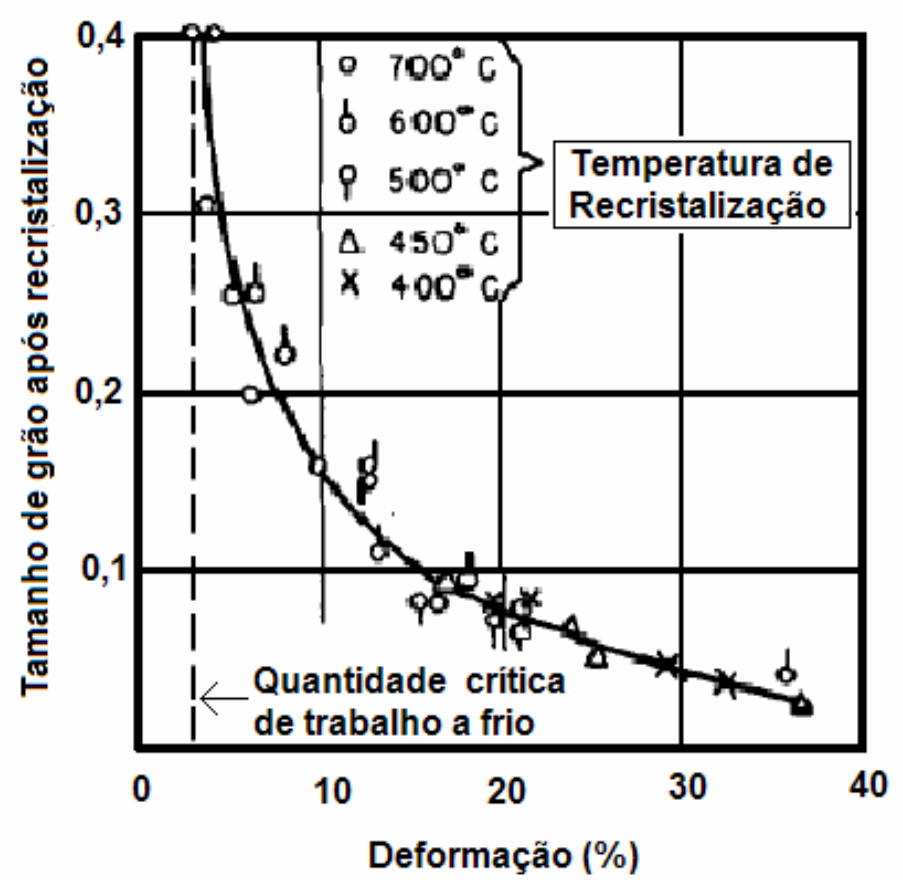

Figura 18: Curva de recristalização de amostras de cobre para diferentes temperaturas de recozimento [23].

A etapa que segue após o período de incubação é caracterizada pelo rápido crescimento dos núcleos de recristalização. Os contornos de alto ângulo avançam sobre a matriz deformada conferindo ao material uma estrutura de grãos cuja distribuição de tamanhos tem caráter bimodal. De fato, interrompendo-se o recozimento antes do término desse estágio, nota-se a presença de grãos recristalizados de tamanho muito superior ao dos grãos deformados da matriz. Esse fato pode ser exemplificado pela figura de Antonione [25] também citada por Landgraf [19] que mostra a estrutura de um material submetido a $2 \%$ de deformação seguida de recozimento à $755^{\circ} \mathrm{C}$ por 260 minutos. Nessa figura, nota-se uma distribuição bimodal do tamanho de grãos. Antonione e Riontino descrevem o período de rápido aumento de tamanho de grão como possuindo características semelhantes ao crescimento anormal, onde poucos grãos crescem rapidamente consumindo os grãos menores da matriz. A migração cessa quando há o encontro dos contornos que delimitam núcleos de recristalização adjacentes. 


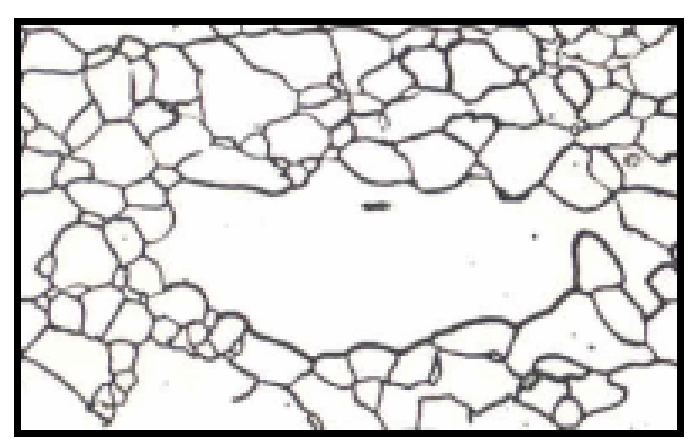

Figura 19: Micrografia de um material com $2 \%$ de deformação submetido a tratamento térmico por 260 minutos à $755^{\circ} \mathrm{C}[25]$.

A evolução da estrutura de grãos durante a etapa da recristalização em que ocorre a migração dos contornos de alto ângulo pode ser observada na Figura 20. Partindo-se da (a) até (e) as fotos mostram a microestrutura de um aço 1006 no estado deformado, após 5 , e 15 minutos de tratamento térmico a $760^{\circ} \mathrm{C}$ e recozido por 6 horas a $760^{\circ} \mathrm{C}$.

(a)

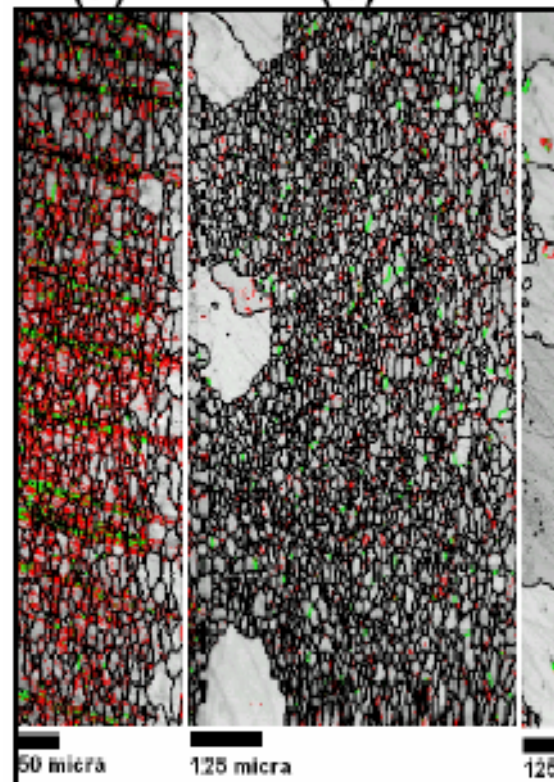

(c)

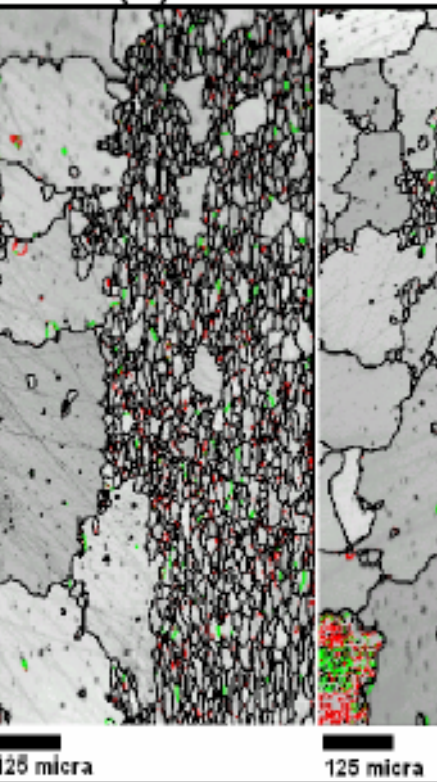

(d)

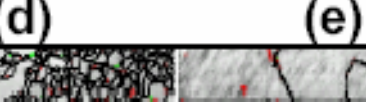

Figura 20: Evolução da microestrutura de um aço 1006 durante a recristalização [26].

As regiões vermelhas e verdes na Figura 20 referem-se às relações de orientação. A cor vermelha indica contornos com relação de orientação entre $1 \mathrm{e}$ $5^{\circ}$ e a cor verde indica relação entre 5 e $10^{\circ}$.

Sobre o efeito da composição na cinética de recristalização dados experimentais publicados por Landgraf comparam as curvas de recristalização para dois aços distintos que, depois de deformados, foram recozidos a $760^{\circ} \mathrm{C}$ por 15 
minutos. Nota-se que a diferença de composição entre esses aços leva a uma diferença no valor da quantidade crítica de trabalho a frio.

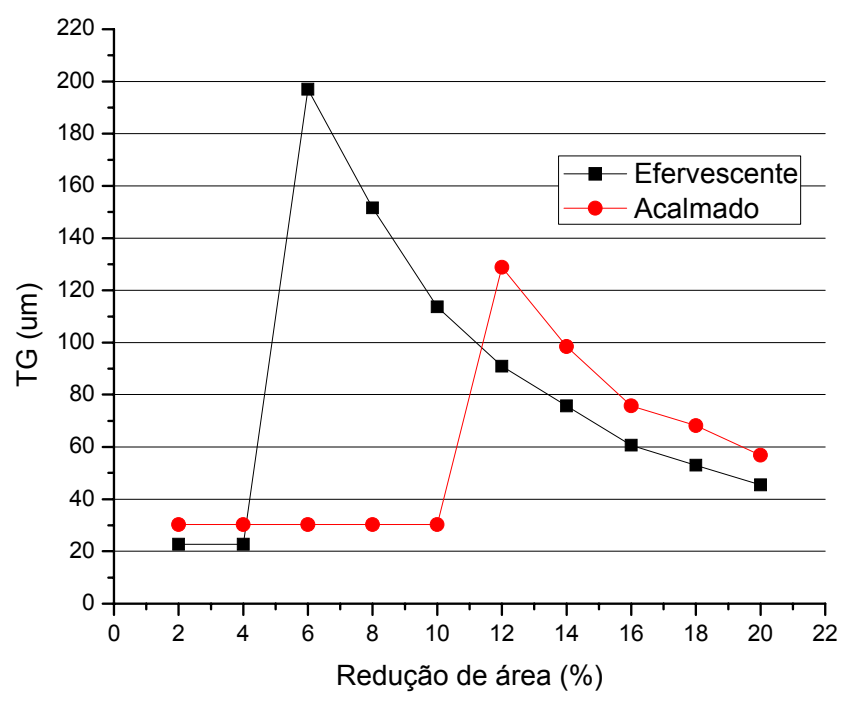

Figura 21: Curva de recristalização para os aços efervescente e acalmado [27].

A nomenclatura, efervescente e acalmado, tem origem no comportamento desses aços durante o lingotamento. No aço efervescente durante a reação de oxidação que leva à transformação do ferro gusa em aço líquido, o oxigênio reage com o carbono presente no ferro gusa para formar monóxido de carbono (CO), gás que tenta escapar do aço líquido, gerando efervescência. Já no aço acalmado pequenas adições de alumínio evitam reações entre o oxigênio e o carbono durante a solidificação impedindo a efervescência [28].

\subsubsection{Aumento do tamanho médio de grãos por crescimento normal}

Hillert [29] define como crescimento de grãos o aumento do tamanho médio de grãos de um material monofásico ou dos grãos da matriz de um material com partículas de segunda fase. A soma das áreas dos grãos individuais é constante, portanto, o aumento do tamanho médio dos grãos está associado com o desaparecimento dos grãos que inicialmente tinham menor tamanho. A força motriz para o aumento do tamanho médio de grãos por crescimento é a energia de superfície dos contornos. Dessa forma, o crescimento busca a re- 
dução de energia livre por meio da diminuição do número (ou seja, redução da área) de contornos pela migração de contornos de alto ângulo [17]. Em amostras submetidas à deformação o crescimento ocorrerá apenas após a recristalização [30]. Característica importante do crescimento normal é que em qualquer instante a distribuição de tamanhos de grão é próxima à distribuição lognormal.

Diversos trabalhos propõem modelos para descrever o mecanismo de crescimento normal dos grãos. Burke e Turnbull afirmam que (em um tratamento bidimensional da questão do crescimento de grãos) grãos com mais de seis lados possuem lados côncavos e tendem a crescer. Já os grãos com menos de seis lados possuem lados convexos e serão consumidos durante o tratamento térmico. É de se esperar que a estrutura mais estável seja composta por grãos de seis lados formando um perfeito arranjo de hexágonos regulares, ou seja, contornos de grãos retos que se encontram formando pontos triplos onde o ângulo entre esses contornos é de $120^{\circ}$. A Figura 22 [31] relata uma estrutura instável de grãos. As setas indicam o sentido da migração dos contornos.

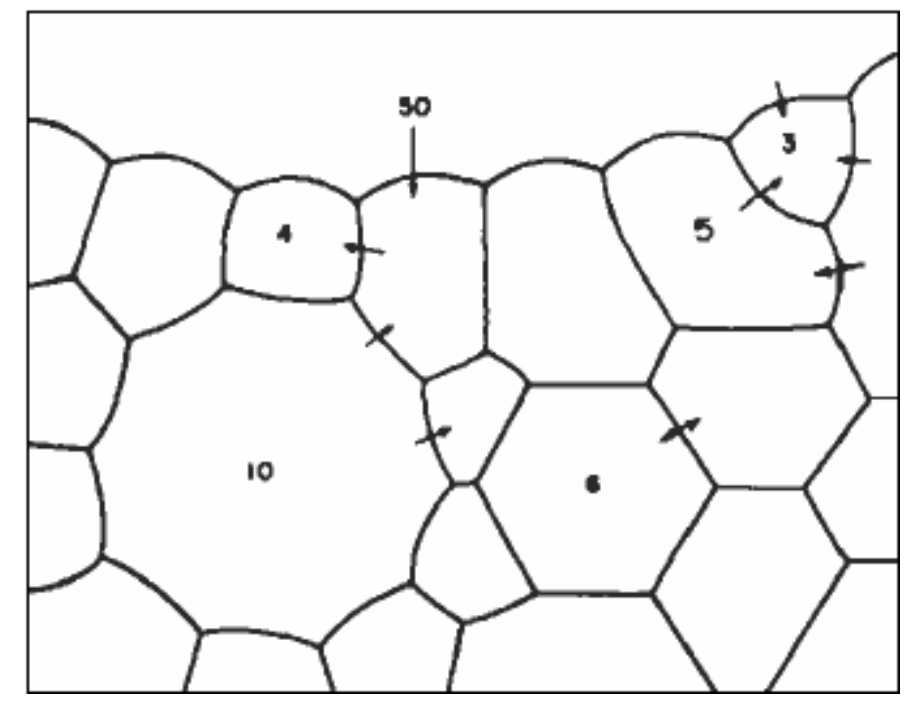

Figura 22: Diagrama esquemático mostrando o efeito do número de lados sobre a curvatura do contorno de grão [31].

O mecanismo proposto por Hillert também trata a questão do crescimento de grão sob o ponto de vista do número e lados. A Figura 23 representa o mecanismo proposto por Hillert. Nessa figura os sinais $+\mathrm{e}-$ no interior dos grãos representam o número de lados que este grão possui a mais ou amenos, respectivamente, tomando-se como referência a estrutura mais estável (grãos com 
seis lados). Ponto de partida para esse mecanismo é a hipótese de que em média cada grão, em uma estrutura bidimensional de grãos, tem em média seis grãos vizinhos. Portanto os grãos dessa estrutura têm em média seis lados. Se por uma imperfeição algum grão possui apenas cinco lados, outro grão na estrutura deve possuir sete lados, há então um "par $5-7$ " que o autor considera como um defeito no arranjo cristalino. Durante o recozimento o grão com cinco lados irá encolher e sua área é aos poucos absorvida pelo crescimento dos grãos vizinhos. Após o desaparecimento desse grão o defeito ainda persiste, porém passa a afetar outro grão e o processo passa a se repetir sucessivamente.

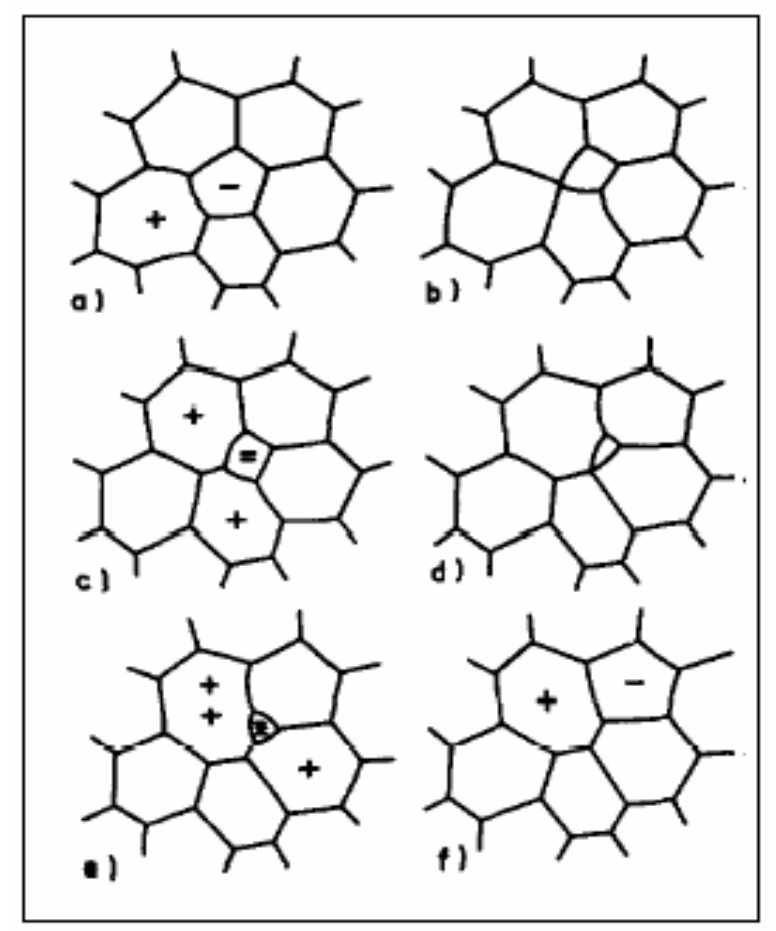

Figura 23: Esquema do mecanismo proposto por Hillert mostrando a evolução da estrutura de grãos durante o recozimento [29].

Cole [32] usou a Equação 9 para descrever o crescimento de grãos durante recozimento isotérmico:

$$
D^{2}-\left(D_{0}\right)^{2}=K_{0} \cdot t \cdot \exp \left(\frac{-H}{k T}\right) \quad \text { Equação } 9
$$


Onde $\mathrm{D}$ e $\mathrm{D}_{0}$ são, respectivamente, os diâmetros no instantâneo e inicial, $\mathrm{K}_{0}$ é uma constante, $t$ corresponde ao tempo e $\mathrm{H}$, é a energia de ativação.

Sidor [33], citando Humphreys [34] refere-se à Equação 10 como a forma geral equação da taxa de crescimento normal dos grãos.

$$
\frac{d \bar{R}}{d t}=M\left(\frac{1}{\bar{R}}-\frac{1}{R_{c}}\right)^{(1 / n)-1} \quad \text { Equação } 10
$$

Nesta equação o raio crítico $\left(R_{c}\right)$ é quem define se um determinado grão irá encolher (e por fim, desaparecer) ou aumentar durante o recozimento. A mobilidade do contorno é dada por M e n está relacionado ao tempo.

\subsubsection{Aumento do tamanho médio de grãos por crescimento anormal}

Na literatura, muitas denominações são encontradas para descrever aumento do tamanho médio de grãos por crescimento anormal. Esse mecanismo de

crescimento é também chamado de crescimento exagerado, crescimento descontínuo, crescimento anômalo e, o termo mais freqüente, recristalização secundária.

O crescimento anormal somente ocorre quando o crescimento normal é impedido e poucos grãos crescem rapidamente consumindo os grãos que permanecem com tamanho aproximadamente constante [35].

Aços silício de grão orientado, usados na construção de núcleos de transformadores apresentam ótimas propriedades na direção de laminação porque possuem uma forte orientação preferencial (110)[001] que recebe o nome de orientação Goss. Essa textura é desenvolvida pelo mecanismo de crescimento anormal [36].

No caso da produção de aços GO a inibição do crescimento normal é provocado pela presença sulfetos de manganês de nitretos de alumínio durante a produção desses aços. Embora o processo de produção de aços GO já esteja consolidado pelos fabricantes de aços para transformadores ainda não está 
claro o motivo que leva ao crescimento preferencial dos grãos com orientação Goss.

O estudo do desenvolvimento da textura Goss serviu de motivação para muitos trabalhos. May e Turnbull [37] estudaram o efeito da adição de impurezas sobre desenvolvimento da textura (110)[001] através do crescimento anormal em ferro silício.

Além da presença de partículas de segunda fase, outros fatores podem provocar o crescimento anormal [17]. Um deles é a presença de "colônias" de grãos grandes (de tamanho maior que a média dos grãos do metal). Essa heterogeneidade de tamanhos faz com que os grãos maiores tendam a crescer avançando sobre os grãos da matriz.

Outro fator a ser citado é a presença de uma textura pronunciada. Neste caso a pequena diferença de orientação entre grãos leva a criação de contornos de baixo ângulo. Estes por sua vez possuem pouca mobilidade. Assim, os poucos grãos cuja orientação foge da orientação preferencial têm contornos de maior mobilidade que avançam sobre os demais grãos da matriz provocando crescimento anormal [17].

\subsection{Sobre o efeito do tamanho de grão sobre as propriedades magnéti- cas em aços elétricos.}

As propriedades magnéticas de um material estão relacionadas à sua microestrutura. Dentre as características microestruturais a de mais fácil medição é o tamanho de grão. O controle do tamanho de grão permite elevar o rendimento de máquinas elétricas através da redução das perdas no ferro. Diante desse fato muitos pesquisadores se esforçam em busca de maior compreensão sobre os mecanismos que relacionam essa importante variável e as diferentes parcelas que compões as perdas magnéticas totais.

Serão listadas aqui algumas publicações que abordam a influência do tamanho de grão sobre as algumas propriedades magnéticas dos aços elétricos.

Dividida em quatro essa seção abordará primeiramente possíveis efeitos dos métodos de aumento de tamanho de grão sobre a textura do material e como isso confere anisotropia às propriedades magnéticas.Logo após, são listados trabalhos referentes ao efeito do tamanho de grão (TG) sobre a perda 
histerética e sobre o campo coercivo. Em seguida serão apresentados trabaIhos que relacionam essa característica microestrutural à perda anômala. Por fim listam-se trabalhos que demonstram o efeito do tamanho de grão sobre a perda total.

\subsubsection{Sobre os métodos de aumento do tamanho de grão e a anisotropia das propriedades magnéticas}

Tamanho de grão e textura cristalográfica são variáveis que afetam as propriedades magnéticas de aços elétricos. As sucessivas etapas de laminação no processo de laminação desses aços conferem ao aço GNO anisotropia das propriedades magnéticas. $O$ efeito da textura cristalográfica é menos compreendido, em virtude da dificuldade de se descrever a textura com poucos parâmetros. É também difícil isolar os efeitos do tamanho de grão daqueles produzidos pela textura. Varáveis de processo que afetam o tamanho de grão também introduzem mudanças na textura. A investigação de anisotropia das propriedades magnéticas é um modo de avaliar os efeitos da textura para cada tamanho de grão.

Tipicamente menores perdas e maiores permeabilidades são obtidas na direção paralela à laminação. Evidência desse fato pode ser feita através da aferição da indução $B_{50}$, indução apresentada pelo material sob um campo de intensidade $5000 \mathrm{~A} / \mathrm{m}$, magnetizando-se o material em diferentes direções tomando-se como referência a direção de laminação conforme mostra Figura 24. 


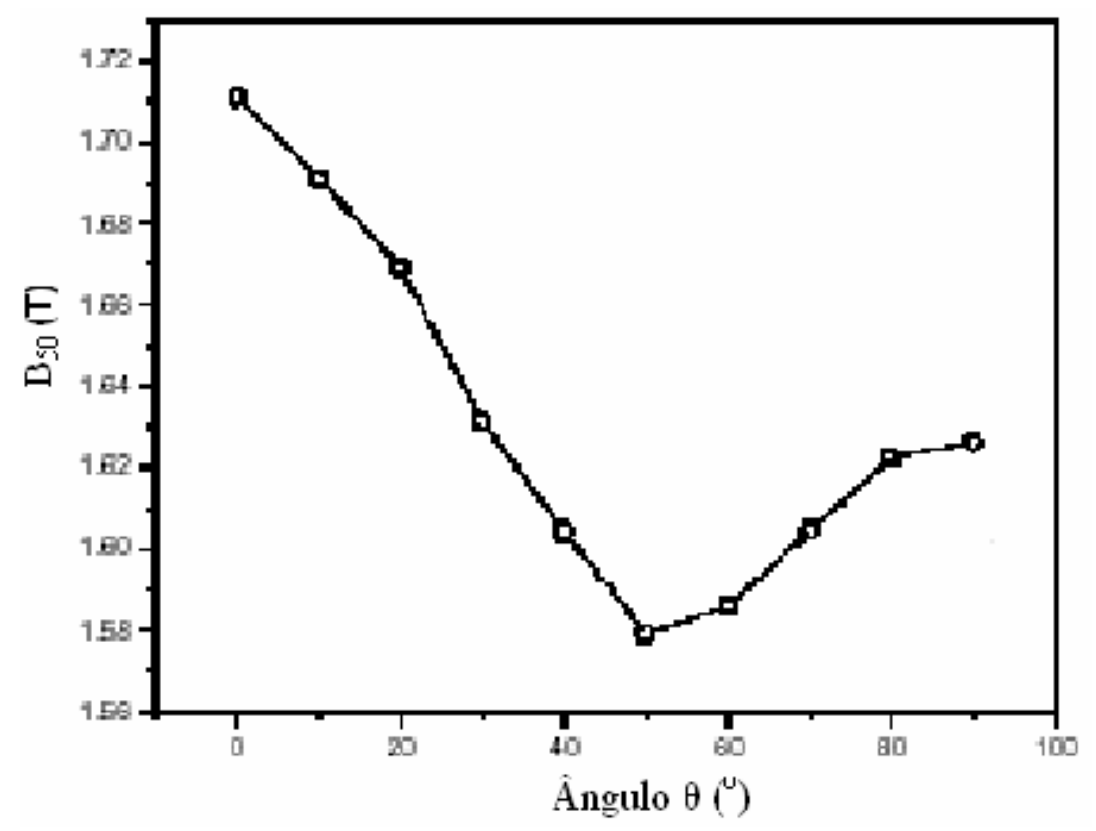

Figura 24: Efeito do ângulo de magnetização com relação à direção de laminação sobre a indução $\mathrm{B}_{50}$ para um aço de $3 \% \mathrm{Si}[38]$.

Analisando amostras laminadas e recozidas, Landgraf relacionou o tamanho de grão após recristalização à indução $B_{50}$ tomada nas direções paralela e transversal à direção de laminação. Os resultados aparecem listados na Tabela 1. Nela é possível observar que com a evolução do tamanho de grão os valores de $B_{50}$ são superiores na direção de laminação indicando fortalecimento da componente (110)[001] na textura. Apenas na amostra de maior deformação houve diminuição do $B_{50}$ na direção de laminação quando comprada ao material apenas recozido, sem deformação prévia [39].

Tabela 1: Efeito da quantidade de deformação sobre o tamanho de grão recristalizado e indução $B_{50}$.

\begin{tabular}{|c|cccccc|}
\hline Deformação & 0,00 & 0,04 & 0,07 & 0,11 & 0,13 & 0,17 \\
\hline TG (um) & 13 & 360 & 163 & 125 & 104 & 48 \\
\hline B50 (DL) & 1,75 & 1,75 & 1,75 & 1,75 & 1,77 & 1,71 \\
\hline B50 (DT) & 1,75 & 1,70 & 1,68 & 1,68 & 1,68 & 1,67 \\
\hline
\end{tabular}

Dados sobre a indução $B_{50}$ para amostras cujos grãos sofreram aumento de tamanho por crescimento foram publicados por Park e Szpunar [40]. Em seu trabalho esses autores produziram, partindo de uma mesma $B Q$, materiais com tamanho de grão distinto (115 e 460 $\mathrm{mm}$, aqui chamadas de A e B, respectiva- 
mente) através de recozimento. Dessas amostras foram produzidas chapas laminadas a frio até espessura $0,5 \mathrm{~mm}$ que recozidas em temperaturas distintas resultaram em amostras de diferentes tamanhos de grão produzidos por crescimento. Os valores de $\mathrm{B}_{50}$ apresentados nesse trabalho são listados na Tabela 2.

Tabela 2: Tamanho de grão e $B_{50}$ das amostras estudadas por Park e Szpunar.

\begin{tabular}{|c|c|c|c|}
\hline \multicolumn{2}{|c|}{ Amostra A } & \multicolumn{2}{c|}{ Amostra B } \\
\hline TG $(\boldsymbol{\mu m})$ & B $_{50}$ & TG $(\boldsymbol{\mu m})$ & B $_{50}$ \\
\hline 23 & 1,708 & 38 & 1,718 \\
\hline 27 & 1,711 & 48 & 1,721 \\
\hline 90 & 1,703 & 86 & 1,715 \\
\hline
\end{tabular}

Esses dados somados a caracterização microestrutural das amostras por ODF levaram os autores a concluir que os maiores valores de $B_{50}$ nas amostras provenientes da $B Q$ de grãos maiores era reflexo de maior presença de grãos com orientação próxima da orientação Goss.

\subsubsection{O efeito do tamanho de grão sobre o campo coercivo.}

Publicado por T. D. Yensen [41] em 1939, o artigo "Magnetically Soft Materials" apresenta uma figura que descreve a evolução do campo coercivo, medido a indução máxima de 1T, em função do tamanho de grão para o ferro puro (Figura 25). O gráfico indica redução no valor das perdas conforme o tamanho de grão é aumentado.

Utilizando o fator de conversão oferecido pela norma ASTM E 112 [42], esta passa a ser uma relação linear entre o campo coercivo Hc e o inverso do intercepto médio, ou seja, $\mathrm{Hc} \propto 1 / \mathrm{d}$. 


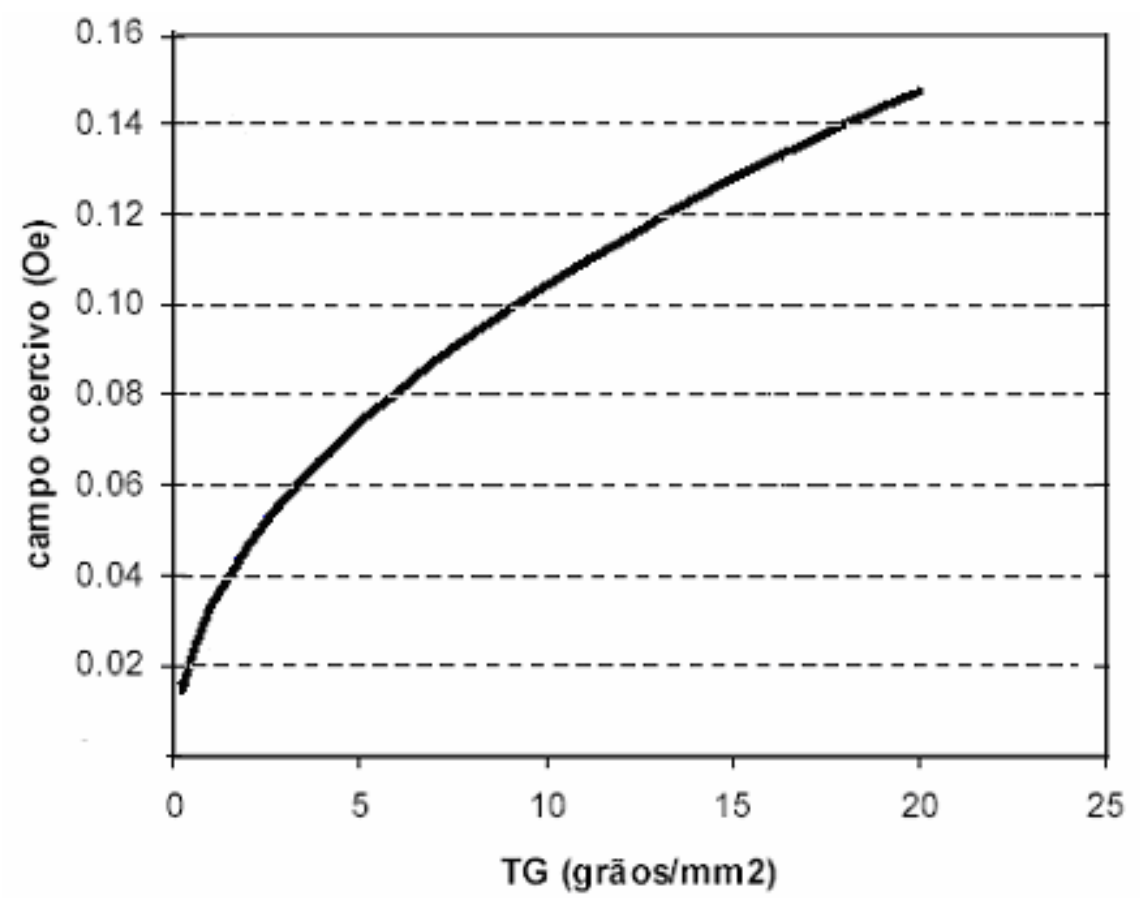

Figura 25: Gráfico obtido por Yensen apud Landgraf onde o comportamento do campo coercivo é dado em função do tamanho de grão.

A relação entre tamanho de grão e campo coercivo foi estudada também por Degauque [43]. As amostras usadas pelo autor foram produzidas a partir de lingotes de ferro que sofreram sucessivos processos de laminação a frio seguidos de recozimento até que chapas de $0,5 \mathrm{~mm}$ de espessura fossem obtidas. Dois diferentes processos de tratamento térmicos foram realizados. As amostras designadas pela letra A na Figura 26 foram recozidas entre 500 e $800^{\circ} \mathrm{C}$ por tempo inferior a 10 horas. As amostras do grupo B foram recozidas com temperaturas entre 440 e $550^{\circ} \mathrm{C}$ por tempo inferior a 60 horas

Degauque encontrou uma relação linear entre o campo coercivo e o inverso do tamanho de grão, porém os dois últimos pontos (correspondentes à região de grãos pequenos) não se ajustam à reta conforme mostra o gráfico da Figura 26. $\mathrm{O}$ autor afirma que incertezas experimentais podem fazer com que a lei $1 / d$ não seja a única possível para descrever o comportamento de Hc. Ele conclui que uma lei $\mathrm{Hc} \propto 1 / \mathrm{d}^{1 / 2}$ não poderia ser excluída. 


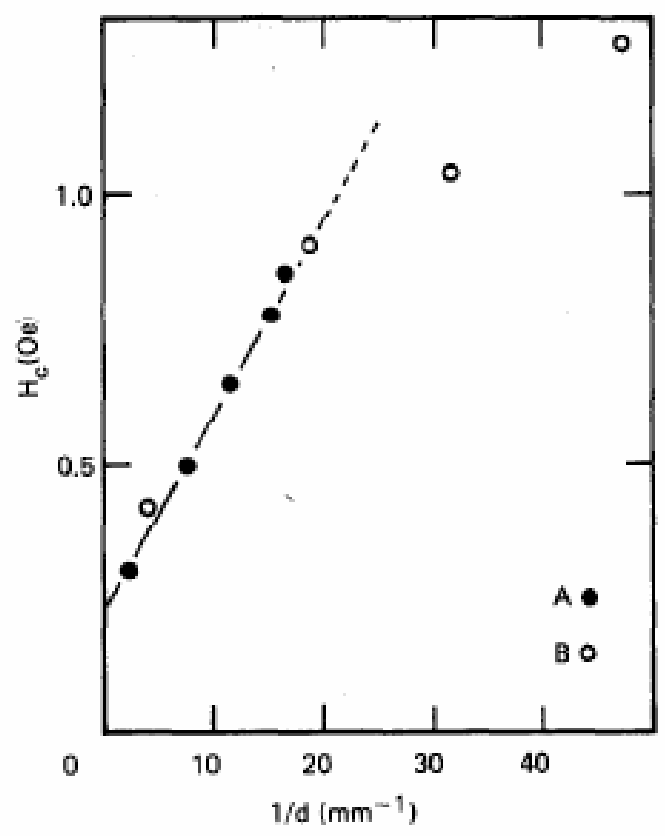

Figura 26: Gráfico de Degauque demonstrando a relação entre campo coercivo e o inverso do tamanho de grão [43].

Experimento semelhante foi realizado por Battistini [44] para aço inoxidável. Em seus resultados o campo coercivo também variou linearmente com $1 / \mathrm{d}$ (Figura 27).

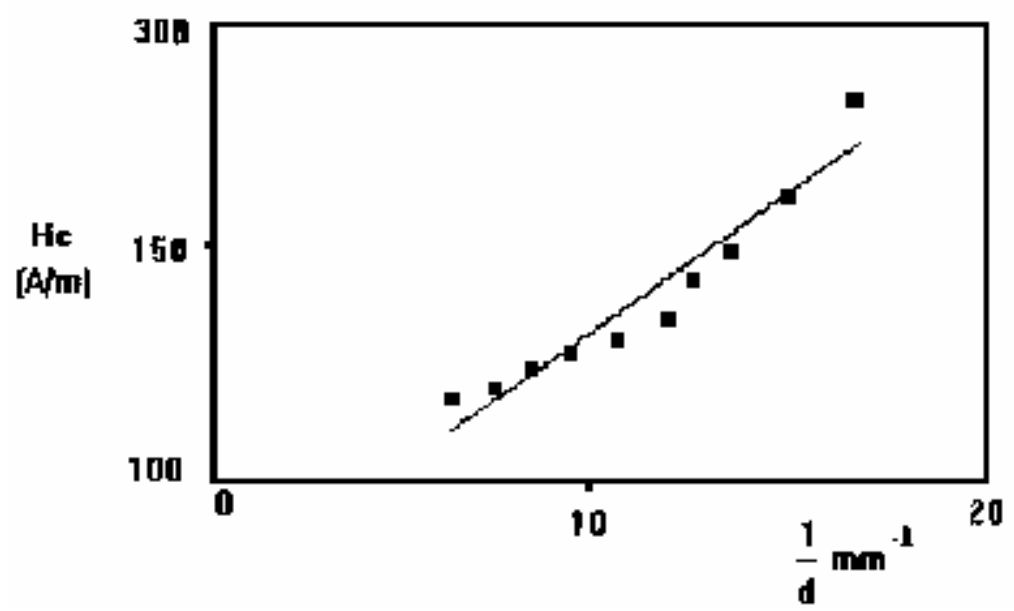

Figura 27: Gráfico campo coercivo em função do inverso do tamanho de grão produzido por Battistini para aço inoxidável [44].

Sobre o comportamento magnético de uma liga NiFe 47,5\%, Adler e Pfeiffer [45] publicaram resultados sobre o estudo da influência de impurezas e tamanho de grão sobre o campo coercivo. Para avaliar o efeito do tamanho de grão eles partiram de material sinterizado de alta pureza, submetido à laminação e recozimento, eliminando toda a porosidade. Nesse trabalho os autores 
concluíram que Hc varia linearmente com o inverso do tamanho de grão, ou seja, $\mathrm{Hc} \propto 1 / \mathrm{d}$ conforme indica o gráfico da Figura 28.

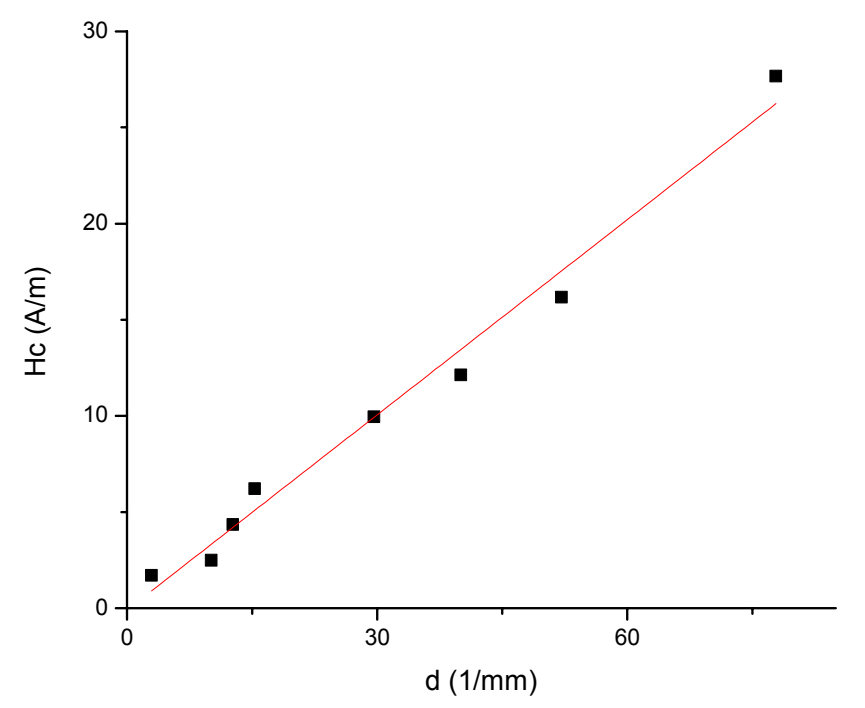

Figura 28: Gráfico campo coercivo em função do inverso do tamanho de grão publicado por Adler e Pfeiffer para amostra de ferro-níquel [45].

\subsubsection{O efeito do tamanho de grão sobre a energia dissipada por histere- se}

Ainda na publicação de Yensen é mostrada uma figura relacionando a energia dissipada em função da histerese a uma indução máxima de 1T ao tamanho de grão em amostras de ferro puro (Figura 29). 


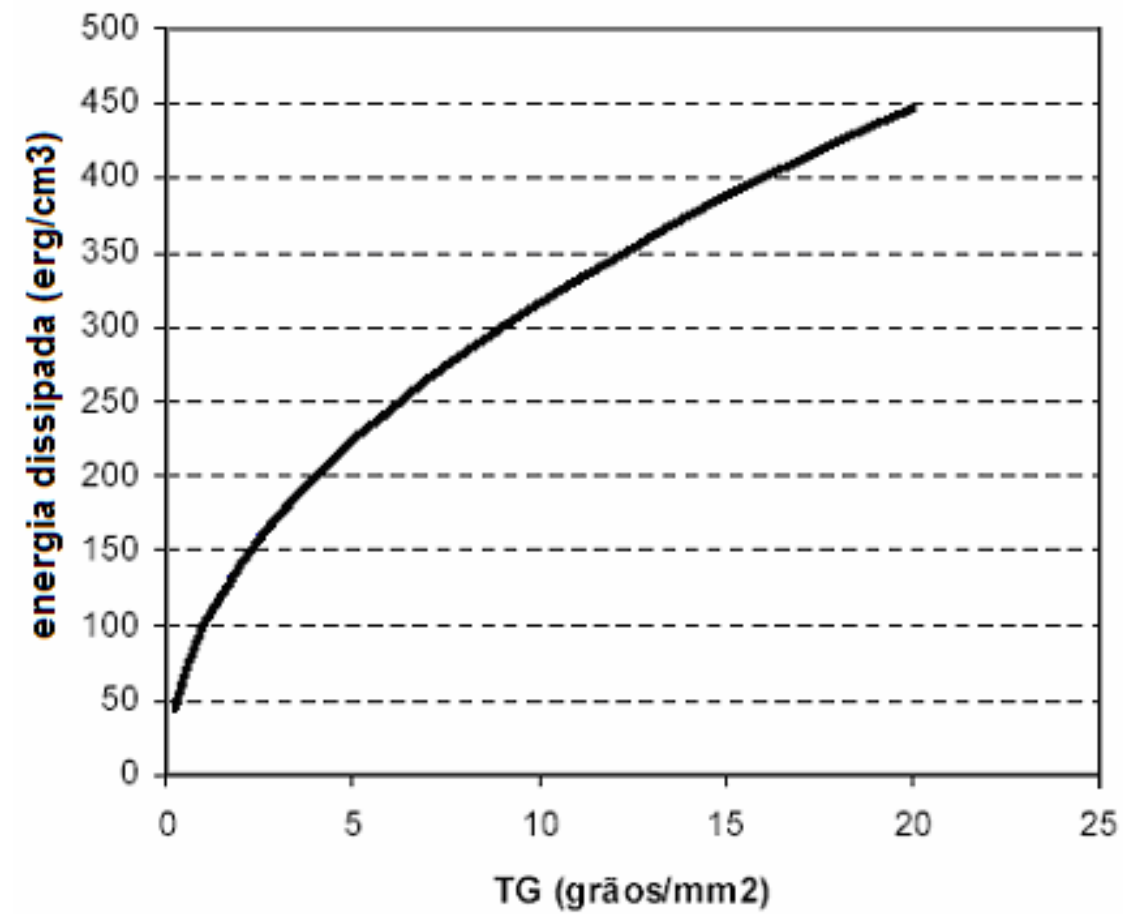

Figura 29: Gráfico obtido por Yensen apud Landgraf onde o comportamento da energia dissipada por histerese é dado em função do tamanho de grão.

Analisando o comportamento magnético de um aço elétrico contendo $3 \%$ Si e 0,4\% Al, Bertotti et al. [46] obtiveram como resultado uma dependência entre perdas histeréticas $(\mathrm{Ph}$, correspondendo à potência dissipada por unidade de massa de material) e tamanho de grão baseada na lei $\mathrm{Ph} \propto 1 / \mathrm{d}^{1 / 2}$ para grãos variando de 15 a 400 $\mu \mathrm{m}$ (Figura 30).

Esse resultado vai ao encontro da afirmação de Degauque sugerindo que a lei $1 / d$ pode não ser a única a descrever o comportamento das perdas histeréticas em relação ao tamanho de grão. 


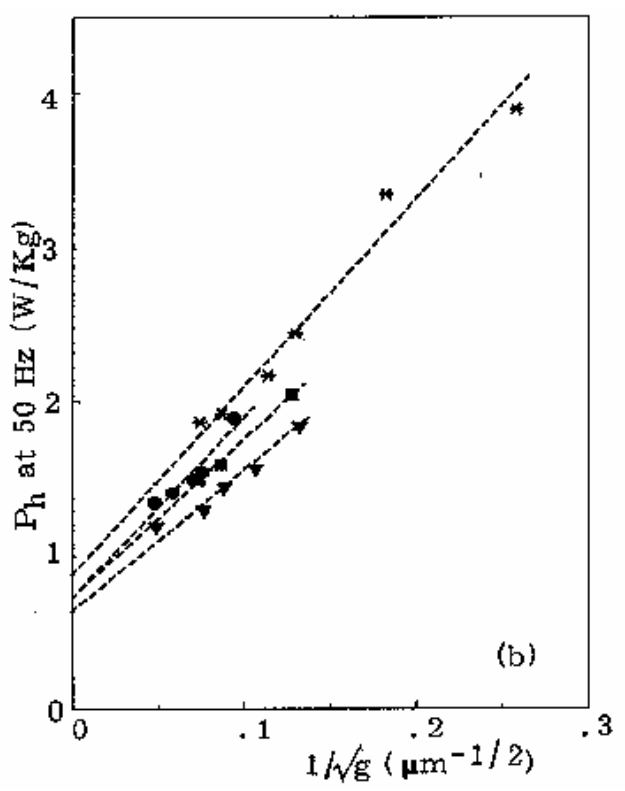

Figura 30: Gráfico de Bertotti relatando as perdas histeréticas em função do inverso da raiz do tamanho de grão [46].

Há, portanto, dúvida sobre a lei que governa o modo como o campo coercivo e a perda histerética se relacionam como o tamanho de grão. Mager [47] propôs um modelo teórico que aponta para uma dependência linear do campo coercivo com o inverso de tamanho de grão.

Trabalho que antecedeu o modelo teórico de Mager foi o publicado por Döring em 1938 [48]. Esse trabalho propôs modelar o crescimento de núcleos de inversão da magnetização em ligas de ferro-níquel. Esses corpos de prova, em formato de fios, submetidos à deformação plástica apresentavam núcleos de tamanho macroscópico detectados por bobinas. Döring propôs uma equação para determinar a intensidade do campo crítico necessário para provocar a nucleação de domínios contrários dada pela Equação 11

$$
H_{S}=\frac{3 \times \pi \times \gamma}{4 \times J_{S} \times d} \quad \text { Equação } 11
$$

onde, y é a energia da parede de domínio, Js é a polarização de saturação e d é um fator geométrico linear.

O modelo de Mager busca estabelecer uma ligação entre o coeficiente da equação empírica de Yensen e a energia da parede de domínios. Esse modelo propõe que os grãos são portadores de núcleos de inversão de magnetização e 
que a equação proposta por Döring é válida mesmo para "mesmo nas complexas estruturas de domínio induzidas pela energia magnetostática nos contornos de grão".

Maiores detalhes sobre seu modelo foram fornecidos por Mager por meio de uma carta destinada a Landgraf. $\mathrm{O}$ autor afirma que em um material policristalino os domínios não são tão grandes no interior de um único grão. Núcleos de reversão da magnetização devem estar em forma de cadeias atravessando diversos grãos. As direções de magnetização no interior dos grãos devem seguir os eixos de fácil magnetização. O campo crítico $(\mathrm{Hs})$ descrito por Döring é a parcela do campo coercivo dependente do tamanho e grão.

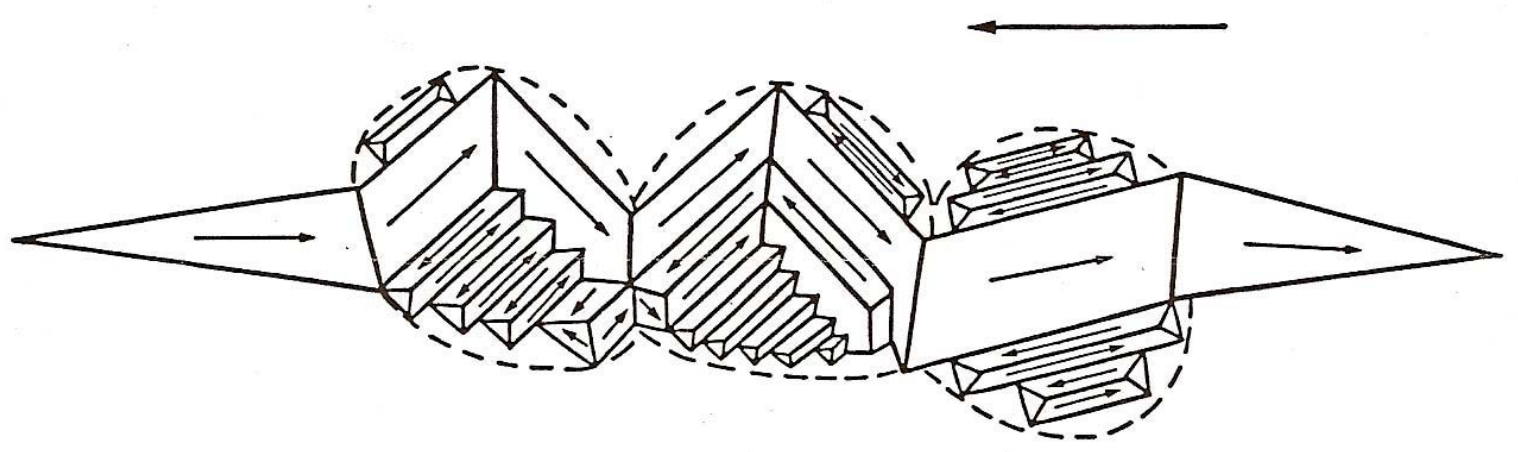

Figura 31: Esboço do núcleo de inversão da magnetização atravessando vários grãos [47].

Desconsiderando a influência do campo desmagnetizante, Mager propõe equação para as três direções do espaço dada pela Equação 12.

$$
H_{S}=\frac{9 \times \pi \times \gamma}{8 \times J_{S} \times d} \quad \text { Equação } 12
$$

Essa equação resulta num coeficiente angular, segundo Mager, de 2,5 $((\mathrm{A} / \mathrm{m})(\mathrm{mm}))$. Número próximo ao valor experimental de Yensen, de 2,32 $((\mathrm{A} / \mathrm{m})(\mathrm{mm}))$. Um aprofundamento da discussão sobre os modelos teóricos para a relação entre campo coercivo e o inverso do tamanho de grão foi realizado por Silveira [49]. 
Não foram encontrados na literatura modelos que apontassem para uma dependência do tipo $\mathrm{Hc} \propto 1 / \ell^{1 / 2}$.

\subsubsection{O efeito do tamanho de grão sobre a perda anômala}

As perdas anômalas, também chamadas de perdas de excesso, são afetadas pelo tamanho de grão. Evidência dessa relação é fornecida em algumas publicações. Em um estudo sobre a dissipação de energia em um aço nãoorientado com 3\% de silício Bertotti [46] apresenta um gráfico do efeito de tamanho de grão sobre a parcela anômala da perda (Figura 32). O comportamento dessa parcela é descrito pelo autor através da relação $P e \propto d^{1 / 2}$, onde $d$ é tamanho de grão.

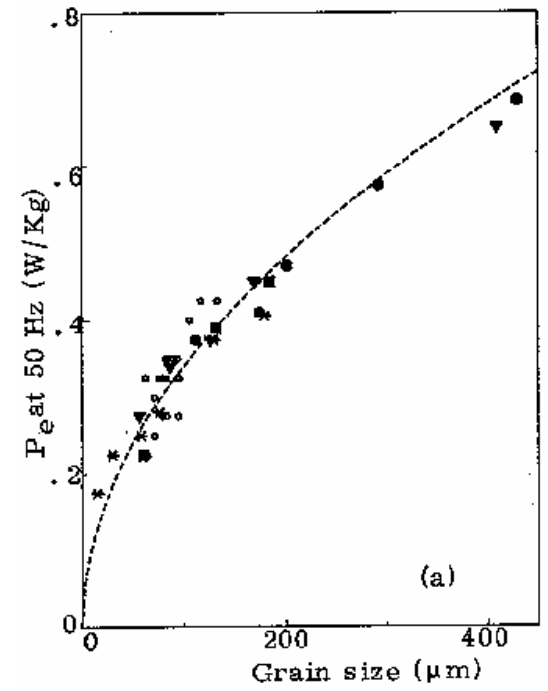

Figura 32: Perda anômala em função do tamanho de grão [46].

Ban e Bertotti [50] produziram ,através de medições em 1,0 e 1,5T a $50 \mathrm{~Hz}$, novas curvas para descrever o comportamento da perda anômala com relação ao tamanho de grão. Nos gráficos da Figura 33 os pontos representam os pontos experimentais para a perda anômala. 


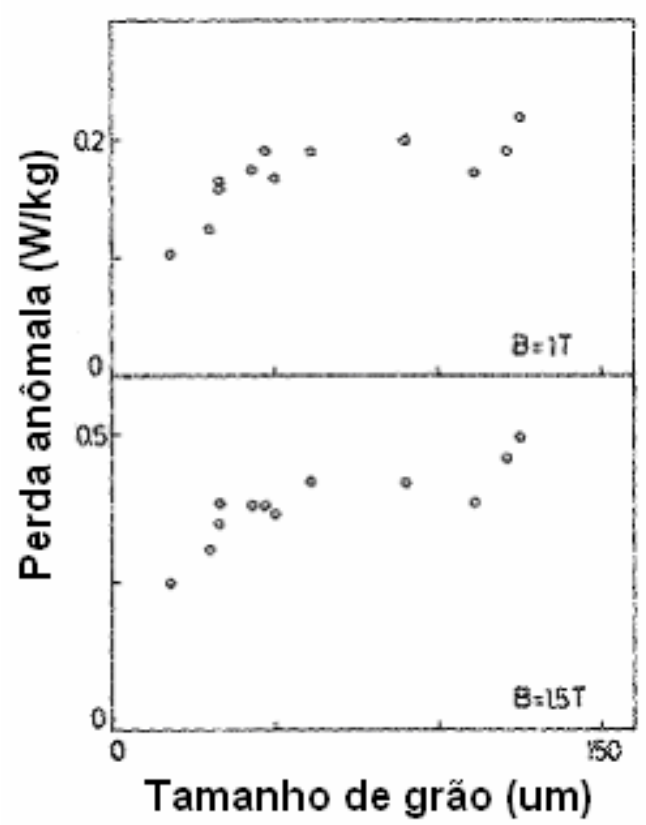

Figura 33: Perdas anômalas medidas a $50 \mathrm{~Hz}$ para as induções 1 e 1,5T em função do tamanho de grão para amostras de aço não orientado com 1,8\% Si [50].

Campos et al. [51] Avaliaram o efeito do tamanho de grão sobre as perdas em aços com 0,5 e $1,5 \%$ de teor de silício para três valores e freqüência $(60$, 150 e $400 \mathrm{~Hz}$ ). Nos três casos a perda anômala (que na Figura 34 é chamada de $\mathrm{Pe}$ ) evolui de maneira quase linear com o tamanho de grão não repetindo os resultados de Bertotti.

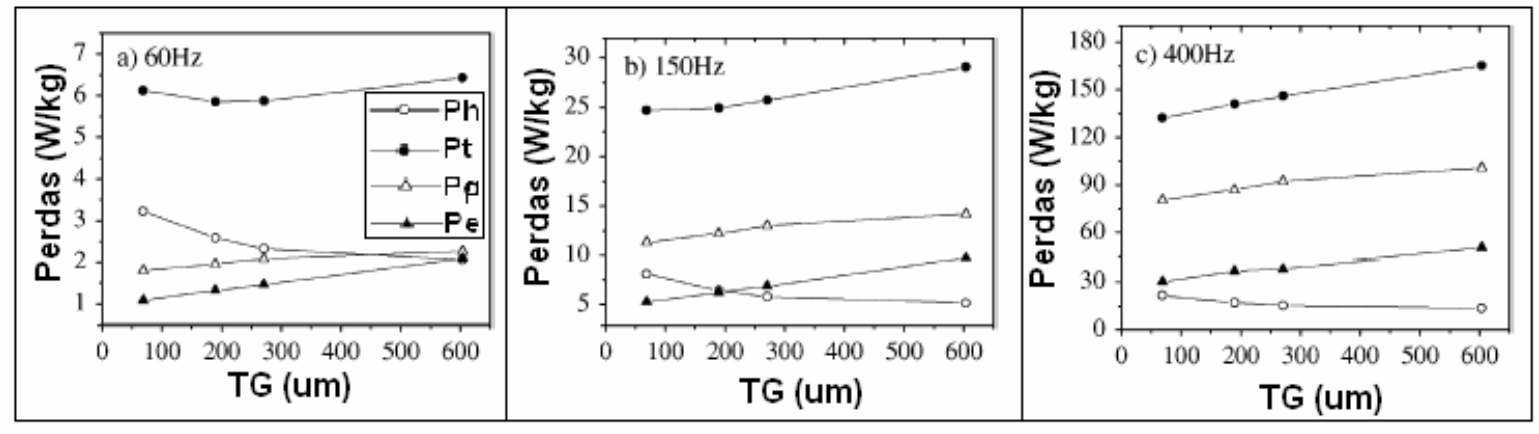

Figura 34: Evolução das perdas com o tamanho de grão e freqüência de excitação em uma amostra de aço elétrico com $0,5 \%$ de silício [51].

\subsubsection{A evolução das perdas totais com o aumento do tamanho de grão}

A influência do tamanho de grão sobre as perdas histerética e anômala acaba por determinar o comportamento das perdas totais com a evolução do TG. Enquanto a perda anômala cresce linearmente com o tamanho de grão a 
perda histerética sempre diminui seu valor. A somatória desses dois efeitos faz com que a curva da perda total se assemelhe a uma parábola onde o valor dessa perda inicialmente cai com o aumento do tamanho de grão, atinge um ponto mínimo e em seguida passa a ser sempre crescente com o aumento do tamanho de grão.

Shimanaka [52] relata que há um tamanho de grão ótimo onde as perdas totais são minimizadas. O autor informa também que o teor de silício é um fator determinante no valor do tamanho de grão que proporciona menor perda total conforme mostra a Figura 35 [52].

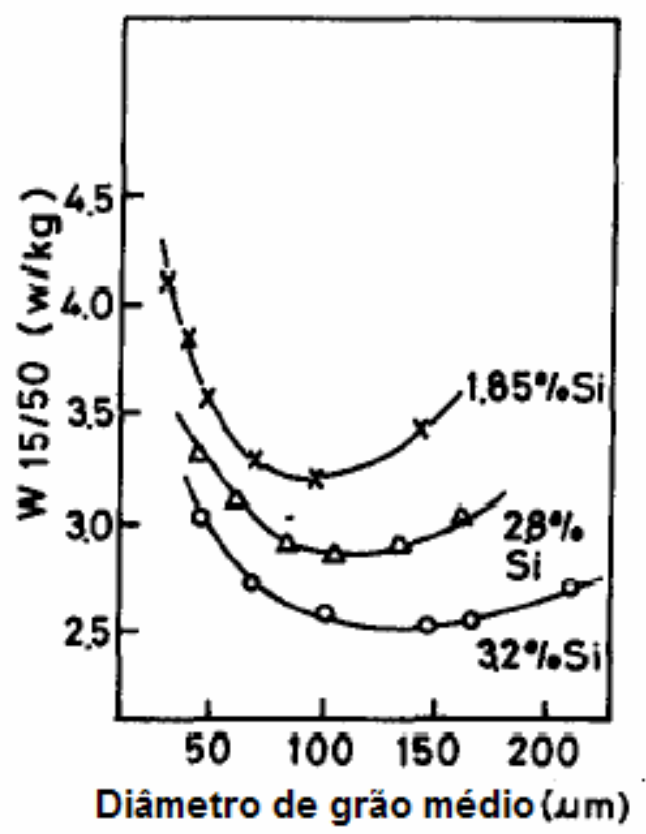

Figura 35: Evolução das perdas totais com o tamanho de grão para aços elétricos com diferentes teores de silício [52].

Também investigando o efeito de tamanho de grão sobre as perdas totais em aços para fins elétricos de diferentes teores de silício, Shiozaki [53] avaliou que o ponto de melhor desempenho corresponde a tamanho de grão $150 \mu m$ (Figura 36).

Suas conclusões diferem de Shimanaka no tocante ao efeito da composição. Enquanto a figura de Shimanaka mostra clara influência do teor de silício sobre o ponto ótimo, os resultados de Shiozaki indicam que o ponto ótimo independe dessa variável. 


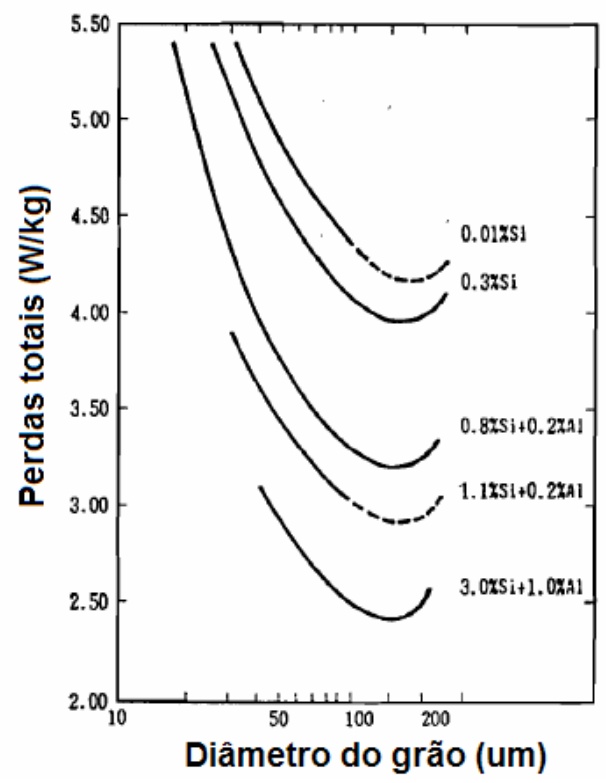

Figura 36: Gráfico das perdas totais $x$ diâmetro do grão produzido por Shiozaki para amostras de aços de diferentes composições [53].

Cunha et al. [54] experimentalmente obtiveram que para ensaio realizado a $60 \mathrm{~Hz}$ com indução máxima de $1,5 \mathrm{~T}$ o ponto de menor perda corresponde a

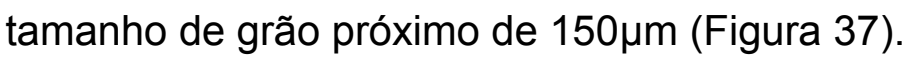

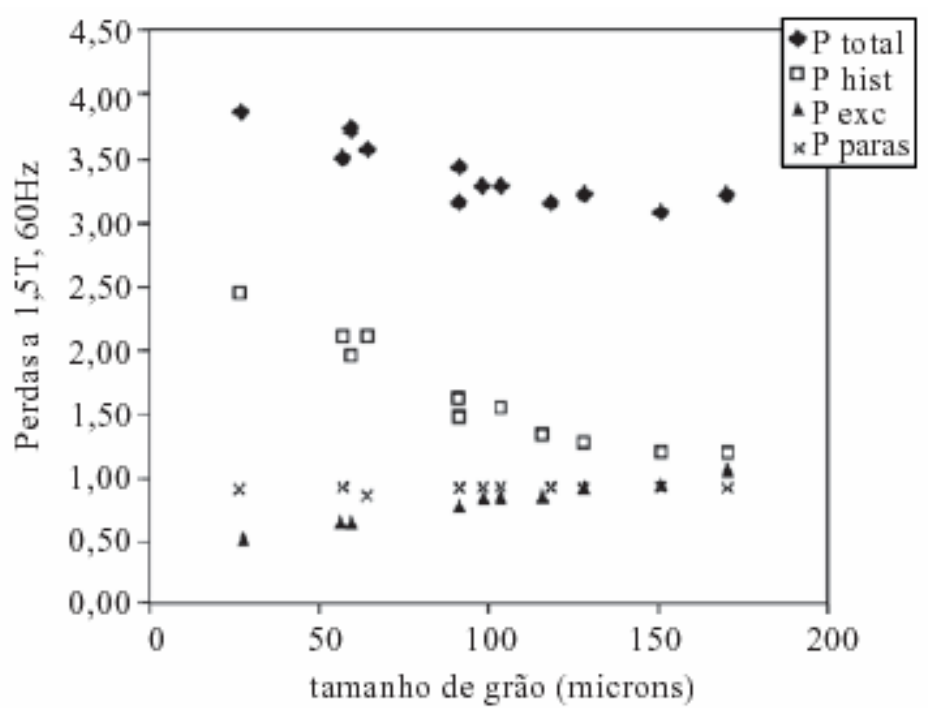

Figura 37: Efeito do tamanho de grão nas perdas magnéticas em um aço com 2\% Si [54].

Takashima [55] corrobora essa afirmação estendendo a faixa de melhor desempenho do material para TGs entre 100 e 150 $\mu \mathrm{m}$. A Figura 38 descreve a evolução das perdas totais com o aumento do tamanho de grão. 


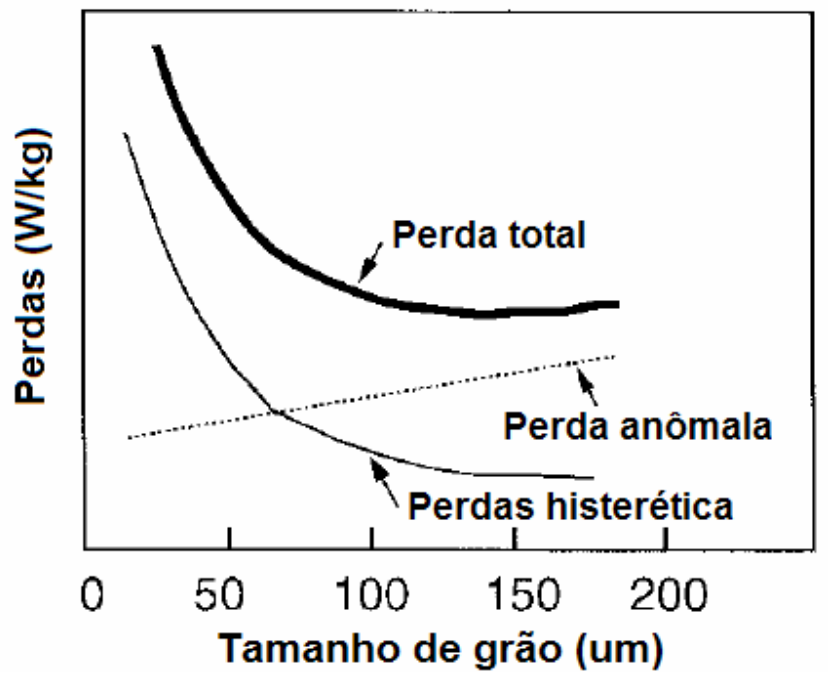

Figura 38: Esboço de um gráfico mostrando o comportamento das perdas total, anômala e histerética com o aumento do tamanho de grão [55].

O valor do ponto de melhor desempenho energético é também dependente da freqüência de excitação, Campos [56] avaliou o efeito da freqüência de excitação sobre as perdas em aços elétricos com 0,5 e 1,5\% de silício. Concluiu que a elevação da freqüência reduz o tamanho de grão que corresponde ao ponto de menor perda total. A Figura 39 mostra os resultados obtidos por Campos para amostra com $1,5 \%$ de silício.
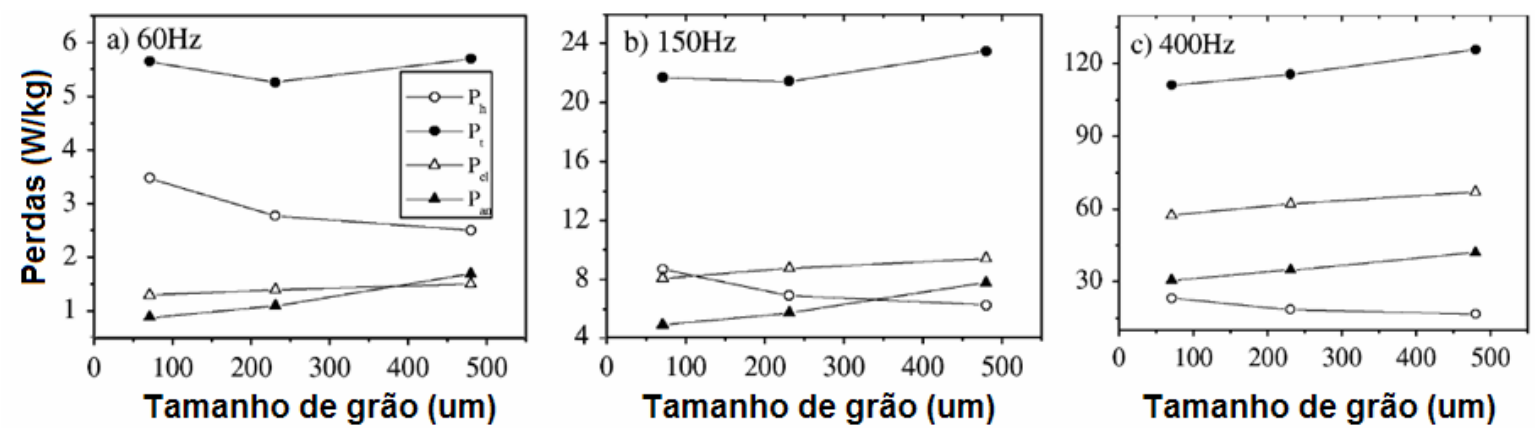

Figura 39: Gráfico das perdas em função do tamanho de grão para ensaios realizados nas freqüências $60 \mathrm{~Hz}, 150 \mathrm{~Hz}$ e $400 \mathrm{~Hz}$ [56].

\subsubsection{O efeito da indução máxima sobre perda histerética e campo coer- civo}

Uma lei simples proposta por Steinmetz [57] ainda em 1892 relaciona a perda histerética à indução máxima de acordo com a Equação 13 , onde Ph é a perda histerética, B é a indução máxima e q chamado de coeficiente de Stein- 
metz e tem valor 1,6. Por sua simplicidade e confiabilidade essa equação é utilizada pelos fabricantes de motores ainda nos dias de hoje para se efetuar estimativas acerca da perda histerética.

$$
P_{h}=k \times B^{q} \quad \text { Equação } 13
$$

Estudos foram realizados para avaliar a equação proposta por Steinmetz e checar a validade do expoente $q=1,6$. Gráfico apresentado por Ball [58], demonstra que o expoente 1,6 não é válido para grandes valores de indução máxima. A Figura 40 traz um gráfico $\log (\mathrm{Ph}) \times \log (\mathrm{B})$. A linha contínua representa os dados observados, a linha pontilhada mostra os resultados esperados caso a lei de Steinmetz estivesse absolutamente correta. Nota-se que há uma mudança de comportamento para induções acima de $B=10000$ gaus (ou, seja $B=1 T$ ) com notável aumento do coeficiente de Steinmetz.

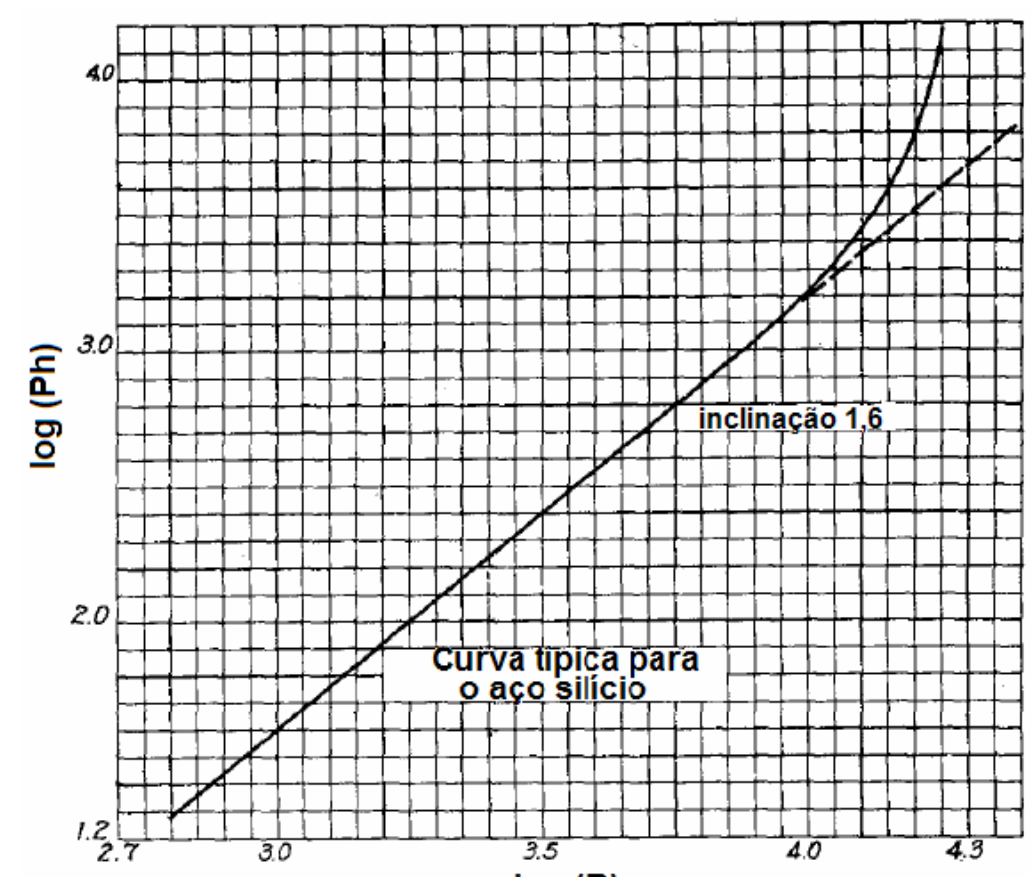

$\log (B)$

Figura 40: Gráfico log (Ph) x log (B) para aço silício [58].

Outros autores avaliaram o intervalo de induções para qual a lei de Steinmetz é válida. Landgraf [59] avaliando aços com 3,2\% e 6,5\% Si concluiu que 
o coeficiente de Steinmetz é válido para o intervalo de induções entre 0,3 e $1,2 \mathrm{~T}$.

Buscando verificar o efeito da indução máxima em chapas submetidas à aplicação de campo magnético em três diferentes direções $\left(0,50\right.$ e $\left.90^{\circ}\right)$ em relação à direção de laminação, Emura [60] pode observar que há uma pequena anisotropia no coeficiente exponencial mas é insuficiente para questionar a validade da lei para o intervalo de induções entre 0,3 e 1,2T (Figura 41).

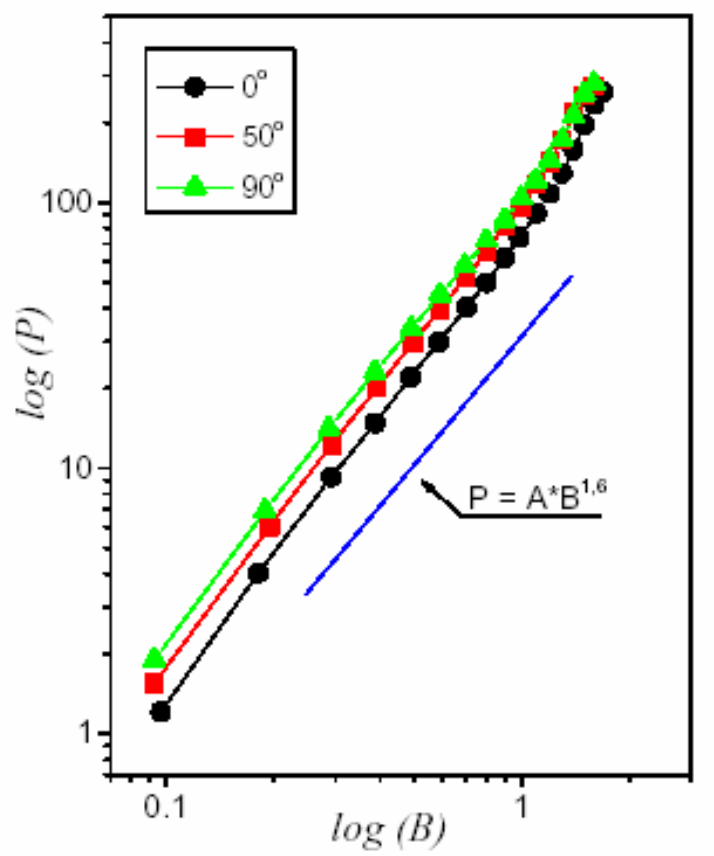

Figura 41: Gráfico log $(\mathrm{Ph})$ x log $(\mathrm{B})$ para as 3 direções de aplicação de campo [60].

\subsubsection{Considerações acerca da relação entre microestrutura e proprieda- des magnéticas.}

Nas seções anteriores foram apresentados trabalhos que avaliaram a relação entre características microestruturais e propriedades magnéticas. Importante questão foi levantada a respeito da lei de dependência que determina a relação entre o campo coercivo e o tamanho de grão.

O trabalho de Yensen, publicado ainda em 1939, aborda essa questão. Embora não apresente pontos experimentais é apresentada a lei de dependência Hc $\propto 1 /$ TG para o ferro puro. Essa tendência é confirmada em alguns trabaIhos posteriores para diferentes materiais. Foram citados Também Adler e Pfeiffer (FeNi), Batistini (aço inoxidável). Ainda assim não há consenso sobre o 
comportamento sobre qual lei de dependência melhor descreve o efeito do tamanho de grão sobre o campo coercivo. Embora Degauque conclua em seu trabalho em favor de $\mathrm{Hc} \propto 1 / \mathrm{TG}$ o autor faz uma ressalva afirmando eu uma lei Hc $\propto 1 / \sqrt{ }$ TG é plausível lançando dúvida sobre o real comportamento do campo coercivo. Experimentos realizados por Bertotti trazem resultados que vão ao encontro da suspeita de Degauque. Yensen e Bertotti apresentam a mesma divergência com relação à energia dissipada por histerese. Portanto, torna-se necessário a produção de mais dados experimentais que possam levar a um consenso sobre o efeito do tamanho de grão sobre o campo coercivo e na dissipação de energia por histerese.

Sobre o efeito da indução máxima na energia dissipada por histerese pode-se dizer que todo o entendimento sobre o assunto está baseado na equação empírica desenvolvida por Steinmetz. Trabalhos posteriores (conduzidos Ball e Landgraf, citados anteriormente) confirmam a validade da equação proposta por Steinmetz mas restringem a validade do seu fator exponencial para uma faixa de indução. Uma evidência da influência de fatores microestruturais sobre os coeficientes da equação de Steinmetz foi apresentada por Emura que observou anisotropia no valor do coeficiente exponencial. Tal anisotropia provoca pequenas alterações no valor do coeficiente de Steinmetz de acordo com o ângulo formado entre o campo magnético externamente aplicado e a direção de laminação da chapa. O efeito da estrutura de grãos não foi avaliado.

Em resumo, embora seja uma variável de grande importância no controle de propriedades mecânicas dos metais, o tamanho de grão ainda gera debate quando se questiona sua relação com as propriedades magnéticas. Portanto, é objetivo deste trabalho levantar dados experimentais que promovam maior entendimento sobre a maneira como o tamanho de grão influencia o campo coercivo e a energia dissipada na histerese. Também é de nosso interesse avaliar o controle que essa variável exerce sobre os coeficientes da equação proposta por Steinmetz. 


\section{MATERIAIS E MÉtOdOS}

Para que se possa avaliar o comportamento das perdas magnéticas e do campo coercivo torna-se necessário a obtenção de conjuntos de amostras de diferentes tamanhos de grão. Cada conjunto é composto de oito lâminas de dimensões $30 \times 300 \mathrm{~mm}$, dimensões estas apropriadas para a caracterização magnética. A aferição do tamanho de grão foi executada na etapa de caracterização microestrutural. Ao todo foram obtidos onze conjuntos de amostras. O procedimento para a obtenção das amostras, caracterização microestrutural e caracterização magnética são explicados mais adiante com maiores detalhes.

O material sob estudo foi o aço elétrico Coscore U260, gentilmente cedido pela Cosipa, cuja composição é descrita pela Tabela 3. Todas as amostras foram extraídas de uma única bobina. O processo de produção do Coscore U260 consiste na solidificação através de lingotamento contínuo resultando numa placa com 250mm de espessura. Por laminação a quente a espessura é reduzida até $2,3 \mathrm{~mm}$. Por fim o aço é laminado a frio até $0,54 \mathrm{~mm}$ e recozido a $640^{\circ} \mathrm{C}$. Este material foi recebido na forma de chapas nas dimensões $1 \times 0,7 \mathrm{~m}$. A densidade e a resistividade elétrica desse material são $7781 \mathrm{~kg} / \mathrm{m}^{3}$ e $27,64 \mu \Omega . \mathrm{cm}$, respectivamente.

Tabela 3: Composição química do Coscore U260, conforme reportado pela Cosipa.

\begin{tabular}{|c|c|c|c|c|c|c|c|c|c|c|c|c|}
\hline $\mathrm{C}$ & $\mathrm{Mn}$ & $\mathrm{P}$ & $\mathrm{S}$ & $\mathrm{Si}$ & $\mathrm{Cu}$ & $\mathrm{Al}$ & $\mathrm{Nb}$ & $\mathrm{V}$ & $\mathrm{Ti}$ & $\mathrm{Mo}$ & $\mathrm{Ni}$ & $\mathrm{Cr}$ \\
\hline $24 \mathrm{ppm}$ & 0,5 & 0,016 & 0,0086 & 0,69 & 0,066 & 0,312 & 0,0024 & 0,013 & 0,001 & 0,056 & 0,0108 & 0,025 \\
\hline
\end{tabular}

\subsection{Obtenção de conjuntos de amostras com diferentes tamanhos de grãos}

Para a obtenção de amostras com diferentes tamanhos de grão foram escolhidos dois processos. O primeiro consiste em aumento do tamanho de grão por recristalização, onde o material como recebido é submetido à deformação plástica por laminação e posteriormente o material deformado é levado para tratamento térmico onde ocorrerá o aumento do tamanho de grão por recristali- 
zação. Por esse procedimento foram obtidos sete conjuntos de amostras cada conjunto com um valor de tamanho de grão.

O outro processo consiste no aumento do tamanho de grão por crescimento de grãos. Para isso, chapas do material como recebido passaram por tratamento térmico apenas. Desse procedimento resultaram quatro conjuntos de amostras. Os procedimentos adotados para os dois métodos de aumento do tamanho de grão são descritos mais adiante.

\subsubsection{Aumento do tamanho de grão por recristalização}

\subsubsection{1 - A etapa de laminação}

A etapa de laminação foi realizada com o objetivo de proporcionar a deformação plástica necessária para que a etapa de recristalização, ocorrida durante o recozimento, resulte em conjuntos de amostras com diferentes valores médios de tamanhos de grão. Para isso tornou-se necessário a obtenção de conjuntos de amostras com diferentes graus de deformação.

Por uma questão de disponibilidade foram usados dois laminadores. $\mathrm{O}$ primeiro a ser utilizado foi o laminador do Departamento de Engenharia Metalúrgica e de Materiais (PMT-USP) com o auxílio do professor Dr. Ronald Lesley Plaut. O segundo laminador utilizado foi do Instituto de Pesquisas Tecnológicas, com auxílio de Sandra Munarim.

O material a ser laminado foi cortado com o uso de uma guilhotina em chapas menores para que elas se ajustassem às dimensões do laminador. Essas chapas foram laminadas mantendo-se o comprimento da chapa paralelo à direção de laminação do material como recebido.

O controle desta etapa foi realizado através da medição da espessura do material laminado. As chapas laminadas foram agrupadas em conjunto de acordo com suas espessuras. As chapas passaram então por nova etapa de corte para a obtenção de lâminas padronizadas com as dimensões exigidas para ensaio no quadro de Epstein, 300×30mm. O comprimento dessas lâminas foi mantido paralelo à direção de laminação. 
Cada uma dessas lâminas teve sua espessura medida em diversos pontos para que fosse verificada a homogeneidade da deformação. As lâminas que apresentavam deformação irregular foram descartadas. Foram selecionados sete conjuntos contendo oito lâminas cada.

Para maior rigor no cálculo do grau de deformação real das lâminas selecionadas, o cálculo da espessura (e) de cada chapa foi realizado através da Equação 14, que fornece a espessura em função do comprimento (c), largura (I), massa (m) e densidade (d) da amostra de acordo com a Equação 14.

$$
e=\frac{m}{l \times c \times d} \quad \text { Equação } 14
$$

O grau de deformação real $\left(\varepsilon_{T}\right)$ foi calculado da apartir da Equação 15.

$$
\varepsilon_{T}=\ln \left(\frac{e}{e_{0}}\right) \quad \text { Equação } 15
$$

A Tabela 4 traz informações sobre o grau de deformação de cada conjunto. Durante a operação de corte foram guardados, para cada conjunto, retalhos de aço que apresentavam o mesmo grau de deformação para posterior caracterização microestrutural.

Tabela 4: Deformação real e espessura dos conjuntos de amostras

\begin{tabular}{|l|c|c|c|c|c|c|c|}
\hline Espessura (um) & 343 & 400 & 451 & 475 & 488 & 501 & 511 \\
\hline Deformação Real & 0,46 & 0,30 & 0,18 & 0,13 & 0,10 & 0,08 & 0,06 \\
\hline
\end{tabular}

Após a etapa de laminação deu-se a etapa de recozimento.

\subsubsection{2 - A etapa de recozimento}

Para proporcionar o aumento do tamanho de grão por recristalização o material laminado foi submetido a tratamento térmico. Os sete conjuntos foram levados à empresa SEW que executou o recozimento. O processo inclui aque- 
cimento por 4 horas, manutenção no patamar a $760^{\circ} \mathrm{C}$ por 2 horas sob atmosfera levemente oxidante, resfriamento lento até $540^{\circ} \mathrm{C}$, patamar nesta temperatura por uma hora sob atmosfera oxidante para produzir camada protetora contra corrosão. Os retalhos correspondentes a cada conjunto também passaram pelo mesmo tratamento. Esses retalhos foram usados na caracterização microestrutural.

\subsubsection{O aumento do tamanho de grão por crescimento}

Foram submetidos a esse procedimento quatro conjuntos de amostras compostos por oito lâminas cada de dimensões $30 \times 300 \mathrm{~mm}$. Essas lâminas foram obtidas através do corte das chapas de material como recebido com o uso de uma guilhotina. Novamente o comprimento das lâminas foi mantido paralelo à direção de laminação do material como recebido.

Desses quatro conjuntos, um foi levado à empresa SEW onde foi recozido de acordo com o procedimento adotado para o recozimento das amostras submetidas à laminação.

O tratamento térmico dos outros três conjuntos foi feito na empresa Embraco, onde cada conjunto passou por tratamento térmico separadamente com tempo e temperatura distintos.

Um dos conjuntos sofreu recozimento para alívio de tensão. Tal procedimento promove diminuição nas tensões introduzidas pelo corte das amostras sem promover crescimento de grãos. Essas tensões devem ser minizadas pois elas têm efeitos sobre propriedades magnéticas do material elevando as perdas. O tratamento para alívio foi realizado a $600^{\circ} \mathrm{C}$ por duas horas em atmosfera composta pelos gases nitrogênio e oxigênio sem umidade.

Os outros dois conjuntos foram recozidos a uma temperatura de $850^{\circ} \mathrm{C}$ sendo um conjunto por quatro horas e outro por oito horas com umidade (ponto de orvalho igual a $5^{\circ} \mathrm{C}$ ). Esse tratamento foi realizado para provocar crescimento de grão. 


\subsection{Caracterização microestrutural}

A caracterização microestrutural consistiu na determinação do tamanho de grão médio através de metalografia. Outro importante objetivo dessa análise foi a observação da distribuição dos tamanhos de grão.

Os retalhos correspondentes a cada conjunto foram embutidos separadamente produzindo-se então onze corpos de prova. O procedimento de preparação seguiu a norma ASTM E3 - 01 [61] e foi executada no plano paralelo à superfície dos corpos de prova.

A superfície de cada um dos corpos de prova foi lixada e depois polida. $\mathrm{O}$ lixamento foi executado em politriz giratória em presença de água. Foram usadas lixas de carbeto de silício nas granulometrias 220, 400, 600, 1200 e 2500 MESH nessa ordem. O polimento se deu com uso de politriz giratória, pasta de diamante de granulometria $1 \mu \mathrm{m}$,como abrasivo, e álcool etílico, como lubrificante. Para que a microestrutura fosse revelada, a superfície das amostras foi atacada quimicamente com uso do reagente Nital 3\%. Após o ataque foram extraídas fotografias da microestrutura dos corpos de prova através de uma câmera integrada a um microscópio óptico. A captura das imagens foi realizada através do Software Micrometrics. A extração das fotos seguiu o procedimento descrito pela norma ASTM que recomenda no mínimo 10 campos ao acaso, com no mínimo 50 grãos em cada, em amostras de aproximadamente 1 polegada quadrada de superfície.

O tamanho de grão médio e sua distribuição foram determinados por método de análise de imagens semi-automático utilizando micrografias da superfície das amostras.

A análise das micrografias foi executada segundo dois métodos distintos: medida do tamanho de grãos pelo método dos interceptos e método das áreas.

\subsubsection{Medição do tamanho de grão pelo método dos interceptos}

No método dos interceptos, circunferências (usadas como linhas-teste) de diâmetros conhecidos foram sobrepostos ás micrografias como mostra a Figura 42. A contagem dos interceptos, pontos onde a linha-teste é intercepta um contorno de grão, seguiu novamente o procedimento descrito pela norma ASTM. 
$\mathrm{Na}$ contagem de interceptos, é contada uma ocorrência para cada ponto onde a linha teste intercepta um contorno de grão. Caso a linha intercepte um ponto triplo, ponto de encontro entre os contornos de três grãos adjacentes, é contado 1,5 ocorrências. Assim determinou-se um tamanho de grão médio para cada campo através da razão entre o comprimento da linha-teste e a e a soma das ocorrências. A média entre os TGs obtidos pelo método dos interceptos para os campos de uma amostra constituiu seu tamanho de grão que aqui será chamado de $\ell$.

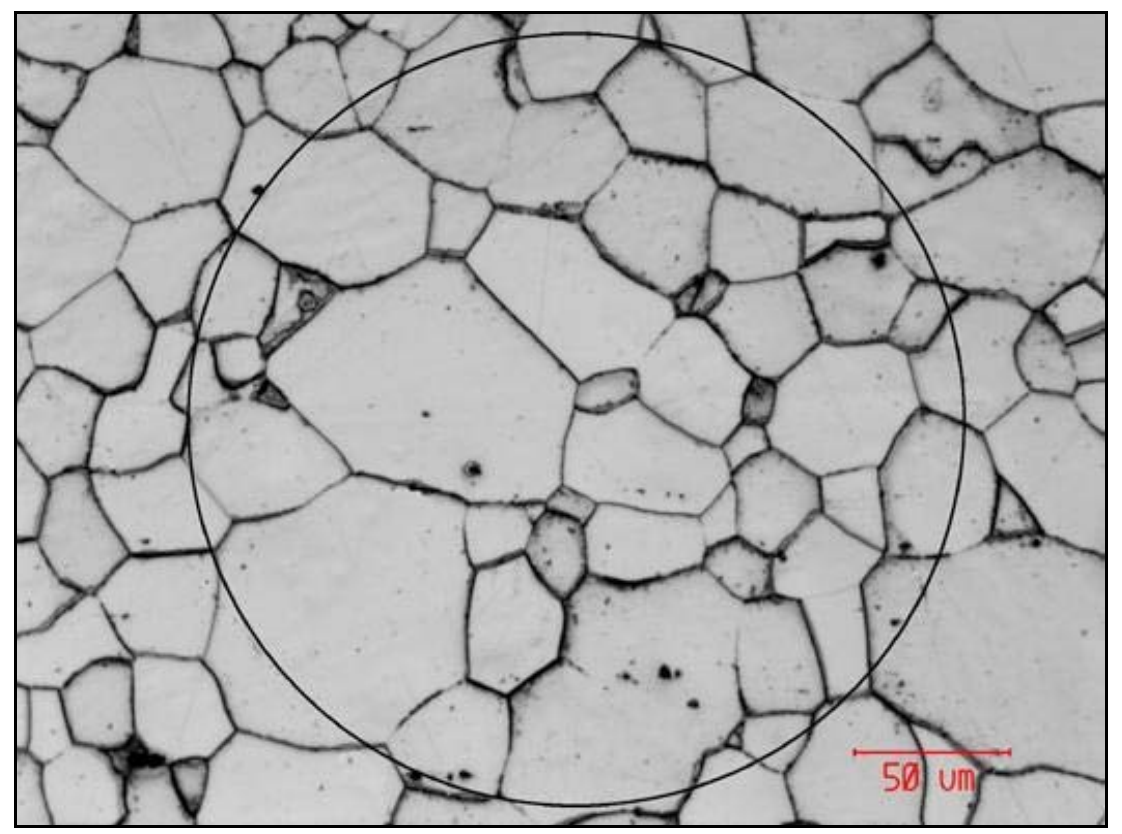

Figura 42: Imagem de uma micrografia contendo a linha teste (círculo no centro da foto) usada para a medição do tamanho de grão pelo método dos interceptos.

\subsubsection{Medição do tamanho de grãos pelo método das áreas}

O método das áreas consiste em um procedimento semi-automático que utilizou o software Altra System. Este software de processamento de imagens permite selecionar individualmente os grãos de uma micrografia e medir a área de cada um desses grãos.

Para que o software possa identificar os contornos de grão torna-se necessário processar a imagem. Isso pode ser feito através de filtros disponíveis no próprio programa. Primeiro aplica-se filtro Separator, que identifica os contornos de grão na imagem. Uma primeira identificação é feita pelo software, porém cabe ao usuário determinar onde estão os contornos e verificar se a i- 
dentificação previamente fornecida é correta. O usuário pode até mesmo "desenhar" os contornos que julgar necessário editando a imagem para tornar o resultado final fiel à microestrutura descrita na imagem pré-processamento. $\mathrm{A}$ Figura 43 ilustra a aplicação desse filtro onde os traços em vermelho são os contornos identificados automaticamente pelo software.

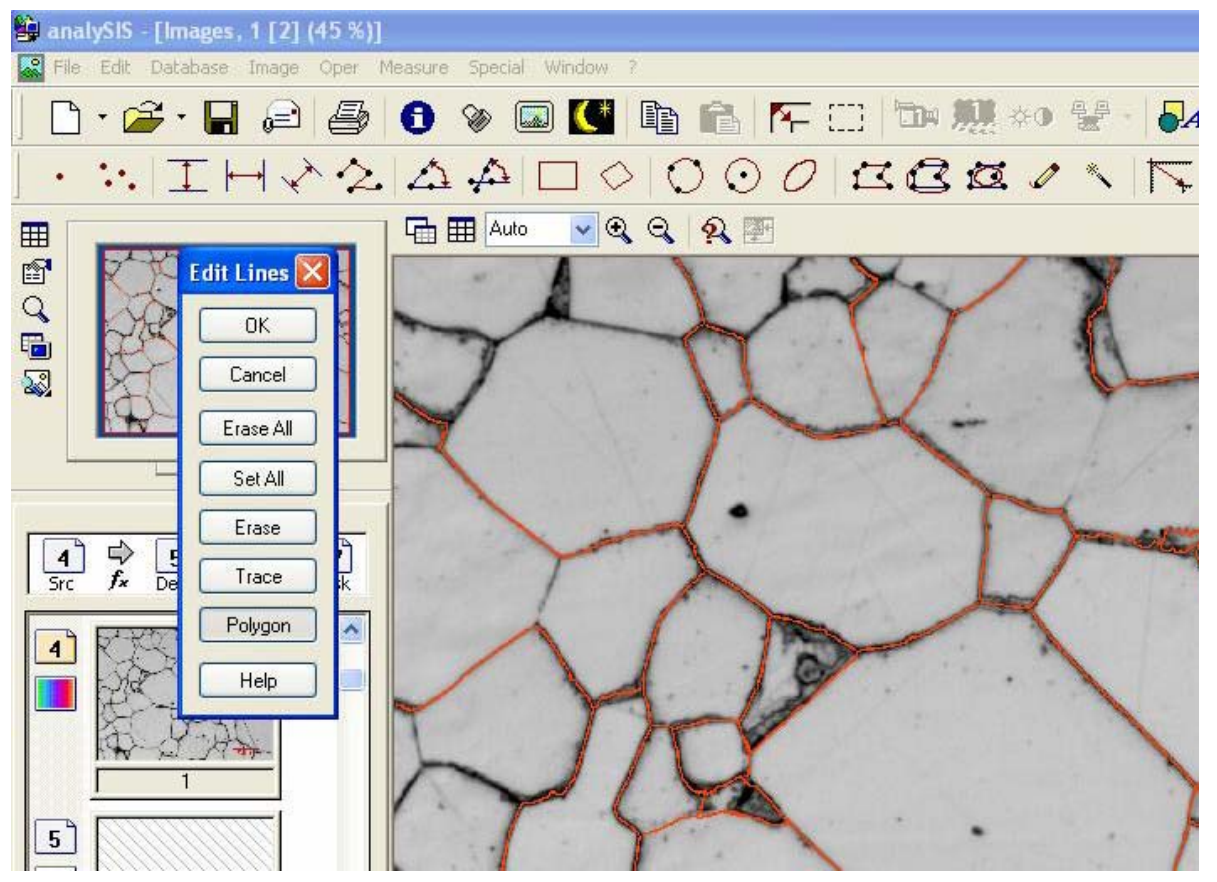

Figura 43: Imagem mostrando os contornos reconhecidos automaticamente pelo software Altra System (linhas vermelhas) através da ferramenta Separator.

Para finalizar o processamento aplica-se o filtro Low Pass que torna a região delimitada pelos contornos (os grãos) sensíveis à ferramenta Magic Wand, esta seleciona individualmente cada grão e fornece a área do mesmo em pixel $^{2}$ que posteriormente é convertido em $\mu \mathrm{m}^{2}$. Um exemplo de imagem após tratamento é dado pela Figura 44. 


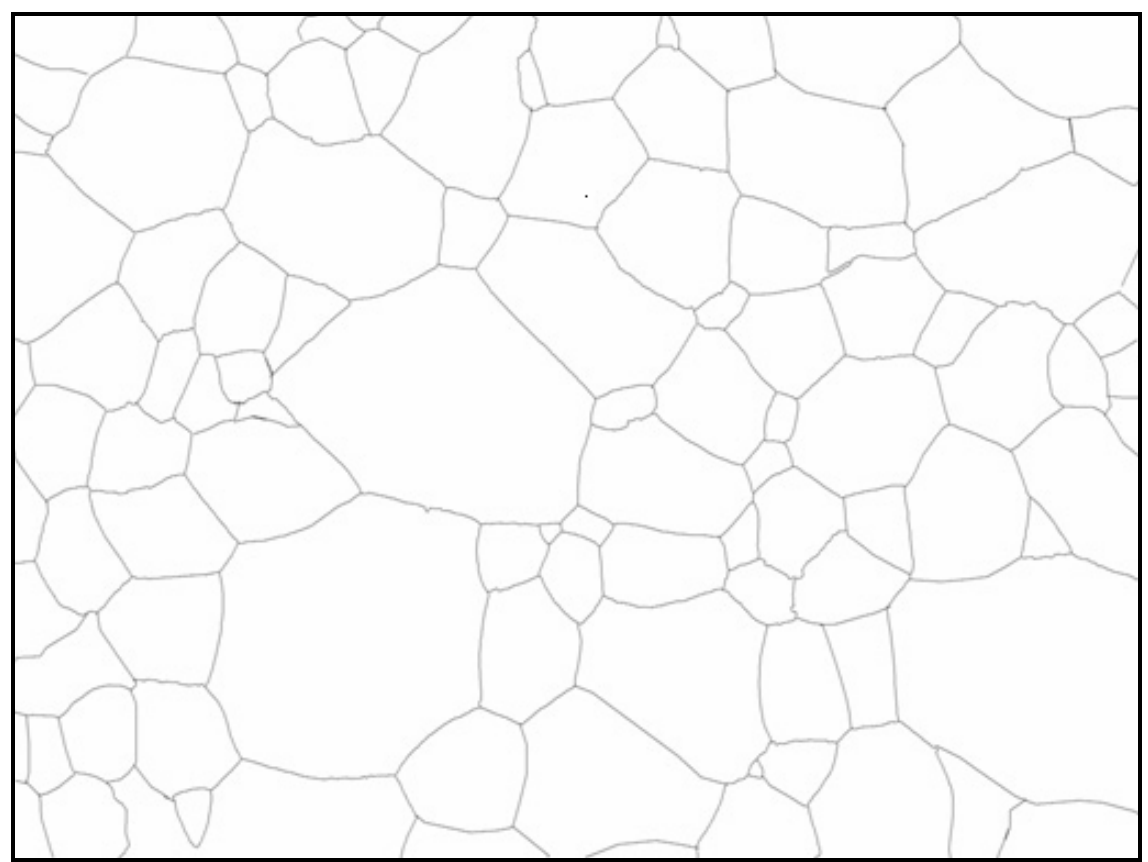

Figura 44: Exemplo de micrografia após aplicação dos filtros Separator e Low Pass.

Cada corpo de prova foi analisado separadamente. Durante a análise apenas os grãos totalmente encompassados pela micrografia foram contabilizados e os dados obtidos para cada campo foram listados em planilhas.

Para tratamento estatístico desses dados, as medidas referentes aos campos de mesma amostra foram reunidas em uma única planilha. Foi calculado o diâmetro equivalente através da Equação 16.

$$
D=2 \times \sqrt{\frac{A}{\pi}} \quad \text { Equação } 16
$$

Os dados foram divididos em classes de tamanho de grão. Para cada classe foi calculada a razão entre a área ocupada pelos grãos pertencentes a essa classe e a área ocupada por todos os grãos contabilizados na análise. Tal razão determinou a fração de área de cada classe.

A determinação do tamanho de grão médio se deu através da média dos diâmetros equivalentes ponderada pela fração de área. O tamanho de grão determinado pelo método das áreas será aqui chamado de dA. Foram produzidos também gráficos que mostram a distribuição do tamanho de grão (dA) com relação à fração de área. 


\subsection{Medidas magnéticas}

As medidas magnéticas foram realizadas no Instituto de Pesquisas Tecnológicas - IPT no Laboratório de Materiais Magnéticos e Metalurgia do Pó. O aparelho utilizado nessa etapa de caracterização foi o quadro de Epstein semelhante ao da Figura 45. Aparelho que consiste de quatro solenóides (cada um composto de duas bobinas) esses solenóides são dispostos de maneira a formar um circuito magnético fechado. As amostras são posicionadas no interior desses solenóides.

As bobinas externas (também chamadas de primárias) são ligadas em série e por elas circula uma corrente elétrica fornecida por um gerador de corrente de forma que essas bobinas passam a fornecer o campo magnético para a magnetização das amostras. Sobre as bobinas internas (secundárias), também ligadas em série, recai a tensão induzida pelas variações de indução magnéticas provocadas pela magnetização e desmagnetização das amostras.

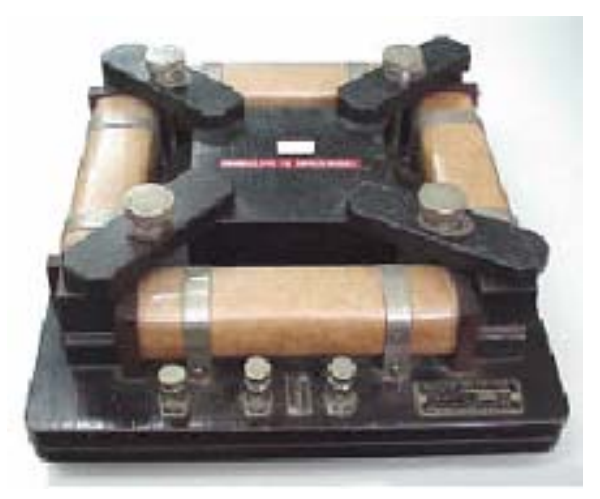

Figura 45: Exemplo de um quadro de Epstein usado para caracterização magnética.

Nesse equipamento foram medidas as perdas totais a $60 \mathrm{~Hz}$, perda histerética a $5 \mathrm{mHz}$ (de onde se extrai a energia dissipada por histerese) e indução $\mathrm{B}_{50}$.

As perdas totais foram medidas sob freqüência de excitação de $60 \mathrm{~Hz}$ nas induções máximas de 1,0 e 1,5T.

$A$ indução $B_{50}$ foi calculada a partir da curva de magnetização do material. A extração dessa curva é feita através da magnetização do material pelo fornecimento de campo magnético crescente variando de 10 a $6000 \mathrm{~A} / \mathrm{m}$. O valor da 
indução $B_{50}$ é obtido pela interpolação dessa curva com o uso do software Origin.

A energia dissipada na histerese foi medida em ensaio quase-estático a $5 \mathrm{mHz}$ nas induções 0,$6 ; 0,8 ; 1,0 ; 1,2 ; 1,4$ e 1,5T. É preciso ressaltar que a informação lida diretamente no aparelho refere-se às perdas histeréticas a $60 \mathrm{~Hz}$ (aqui chamada de $\mathrm{Ph}$ ) o valor da energia dissipada na histerese $(\mathrm{Wh})$ foi calculado apartir da área do ciclo de histerese através da Equação 17, onde $f$ corresponde á freqüência $(60 \mathrm{~Hz})$ e d é a densidade do material.

$$
W h=\frac{P h \times d}{f} \quad \text { Equação 17 }
$$

Apartir dos resultados do ensaio quase-estático foram plotadas as curvas de histerese magnética de onde foi extraído o campo coercivo (Hc). Para cada amostra e foram plotados gráficos que descrevem o comportamento do campo coercivo e da energia dissipada por histerese com relação ao tamanho de grão. Ainda sobre a energia dissipada por histerese, foi construído um gráfico Wh em função da indução máxima (Bmax).

Para assegurar a confiabilidade e a reprodutibilidade dos ensaio em regime quase-estático quatro conjuntos de amostras foram enviados ao Instituto Nacional de Metrologia, Normalização e Qualidade Industrial - Inmetro. No Inmetro amostras foram submetidas à caracterização magnética em quadro de Epstein em regime quase-estático para indução máxima de 1,5T. Os resultados (ciclos de histereses e campo coercivo) foram, por fim,comparados. 


\section{Resultados e discussão}

\subsection{Sobre o aumento do tamanho de grão.}

\subsubsection{Aumento do tamanho de grão por recristalização.}

A influência do grau de deformação sobre o tamanho de grão do material após recristalização é descrito pela Figura 46 que relaciona o grau de deformação real ao tamanho de grão determinado após a etapa de recristalização pelo método dos interceptos.

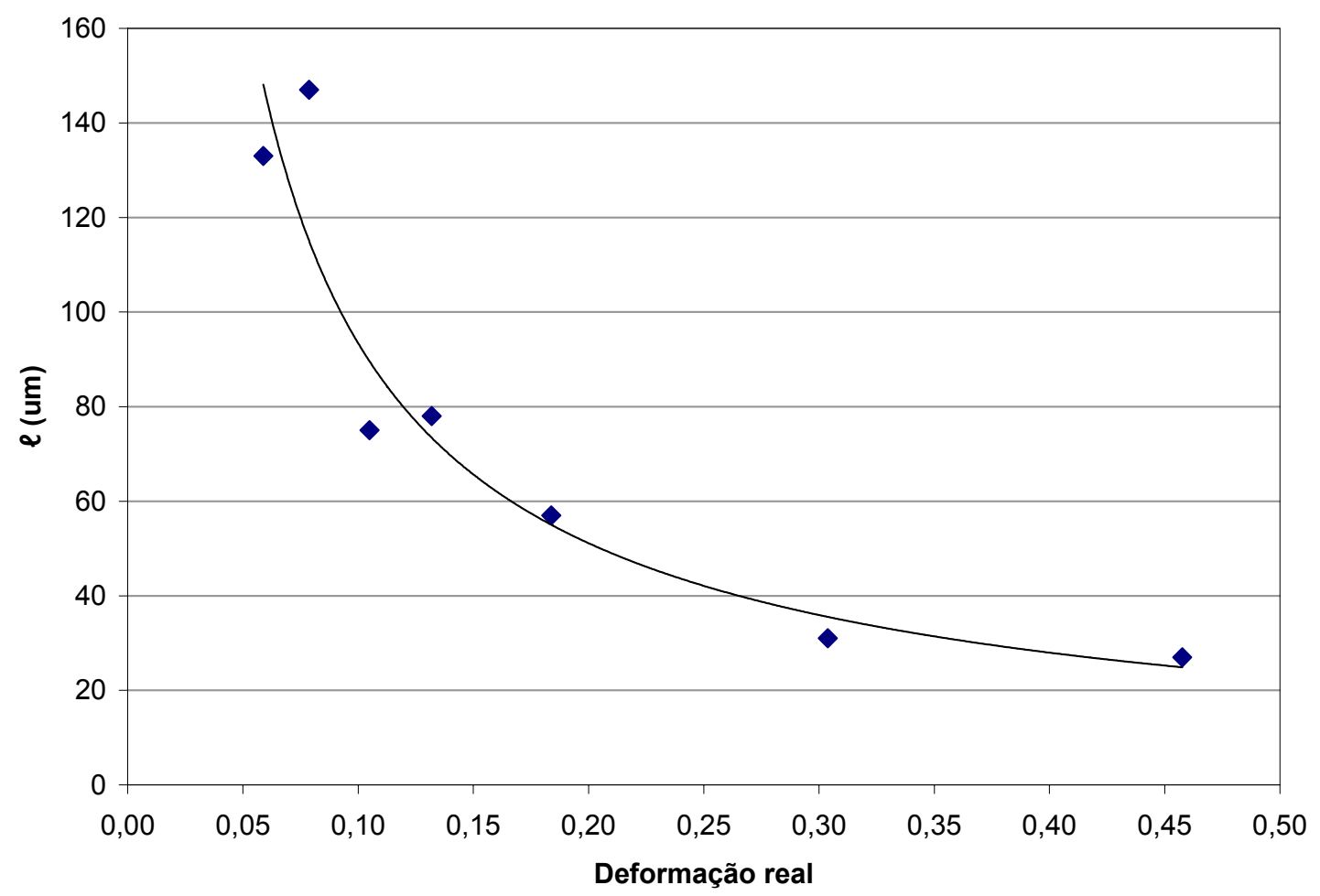

Figura 46: Gráfico da Deformação real em função do tamanho de grão $(\ell)$ para as amostras submetidas a aumento de tamanho de grãos por recristalização.

Analisando a Figura 46 observa-se que o comportamento se segue, de maneira geral, o previsto por Burke e Turnbull [30], ou seja, pequenos graus de deformação proporcionam grande tamanho de grão recristalizado. Pode-se notar que apesar da validade de uma das leis da recristalização (a que define que o aumento do grau de deformação proporciona menor tamanho de grão após recristalização), os pontos experimentais não a obedeceram estritamente. Os 
resultados experimentais indicam que os pontos de menor deformação não apresentam o comportamento previsto por essa lei de recristalização. Esses desvios podem ocorrer em função de heterogeneidades de deformação ocorridas no processo de laminação.

Extraindo-se os dados da Figura 16 de Ashbrook [18] e somando-se a esses dados os resultados obtidos por Landgraf [39] pode-se traçar novas curvas de recristalização. Uma comparação entre os resultados de Ashbrook, Landgraf e os resultados obtidos no procedimento de aumento de tamanho de grão por recristalização (que na figura são chamados de SEW) é dada na Figura 47.

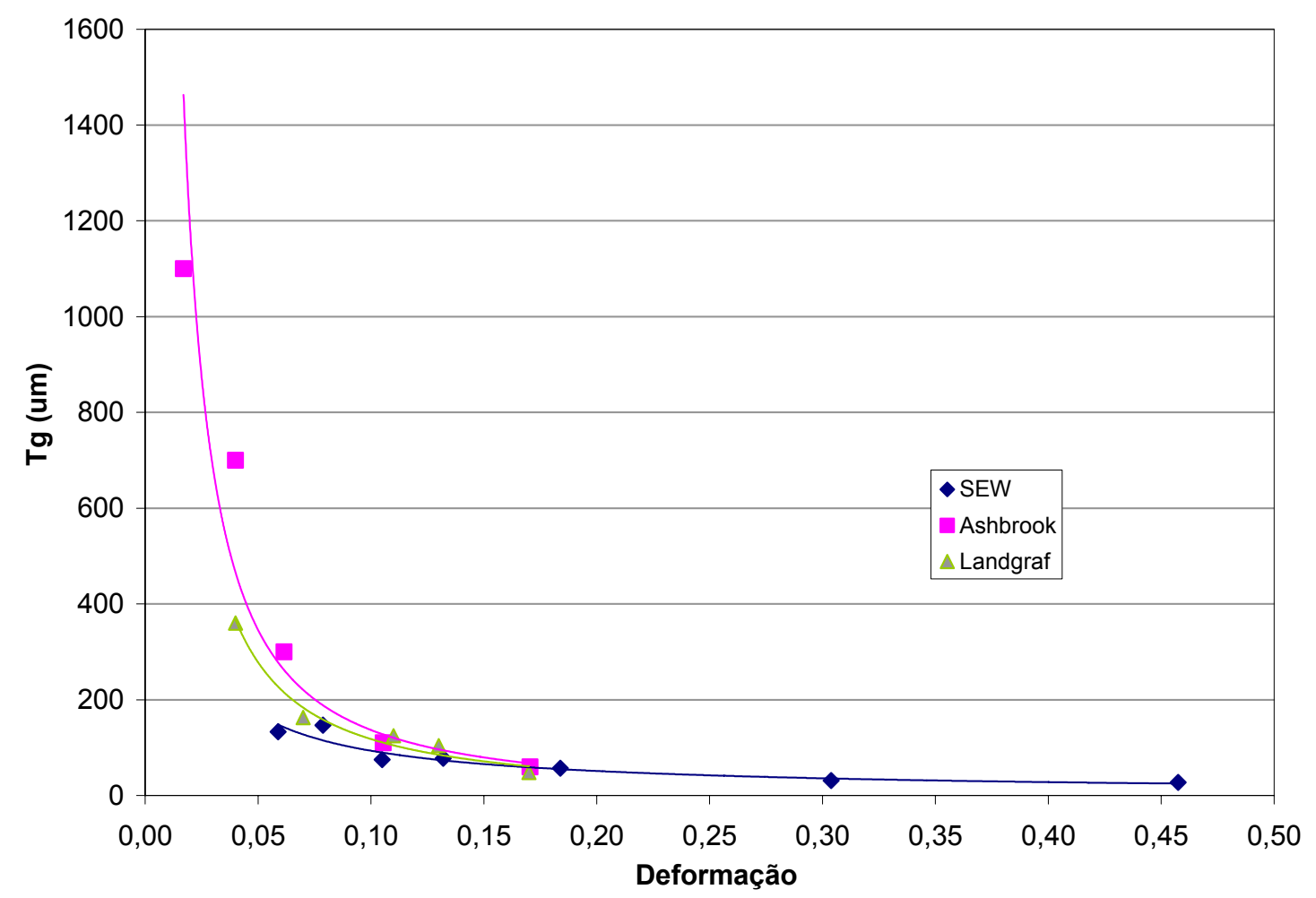

Figura 47: Curvas de recristalização com os resultados extraídos de Ashbrook [18] e os obtidos no processo de aumento de tamanho de grão por recristalização (indicados por SEW).

Adotando uma simplificação onde o volume médio dos grãos pode ser definido como $\ell^{3}$ pode-se esboçar um gráfico que relaciona a quantidade de grão por volume (após crescimento por recristalização) à quantidade de deformação fornecida antes do recozimento. Essa informação é dada na onde a quantidade de grãos por unidade de volume é dada por $1 / \ell^{3}$. 


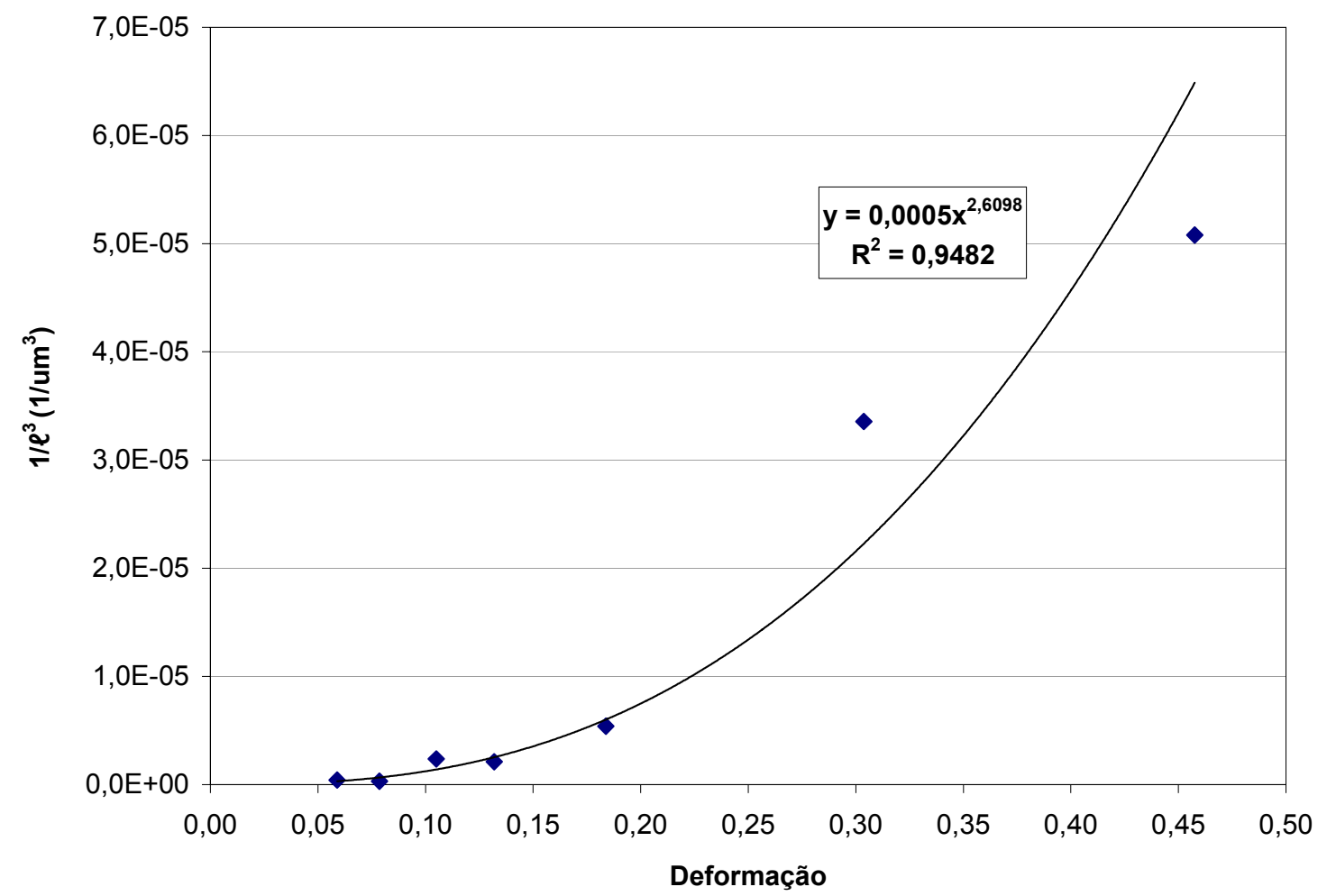

Figura 48: Gráfico $1 / \ell^{3} x$ deformação para as amostras submetidas a aumento do tamanho de grão por recristalização.

A Figura 49 traz a distribuição dos tamanhos de grão das amostras onde o aumento do tamanho de se deu por recristalização. Cada um dos gráficos de distribuição de tamanho vem acompanhado de uma micrografia (posta à direita do gráfico) da amostra relatando sua estrutura de grãos.

Essas distribuições estão mostradas na forma de gráficos onde o eixo das ordenadas representa os valores de fração de área indo de 0,00 a 0,12. 0 eixo das abscissas indica o diâmetro equivalente (dA) dado em $\mu \mathrm{m}$. Os tamanhos de grão estão divididos em classes, cada classe ocupando uma fração de área. Nesta figura as amostras estão identificadas de acordo com a deformação fornecida na etapa de laminação, pela temperatura e tempo de recozimento, estes dois últimos estão escritos entre parênteses. Dessa forma, a identificação de cada conjunto de amostra está descrita nos gráficos no seguinte padrão: deformação real (temperatura/tempo). A amostra indicada por 0,00 $\left(600^{\circ} \mathrm{C} / 2 \mathrm{~h}\right)$ refere-se á amostra submetida a tratamento térmico sem deformação para alívio de tensões a $600^{\circ} \mathrm{C}$ por duas horas sem deformação prévia. 

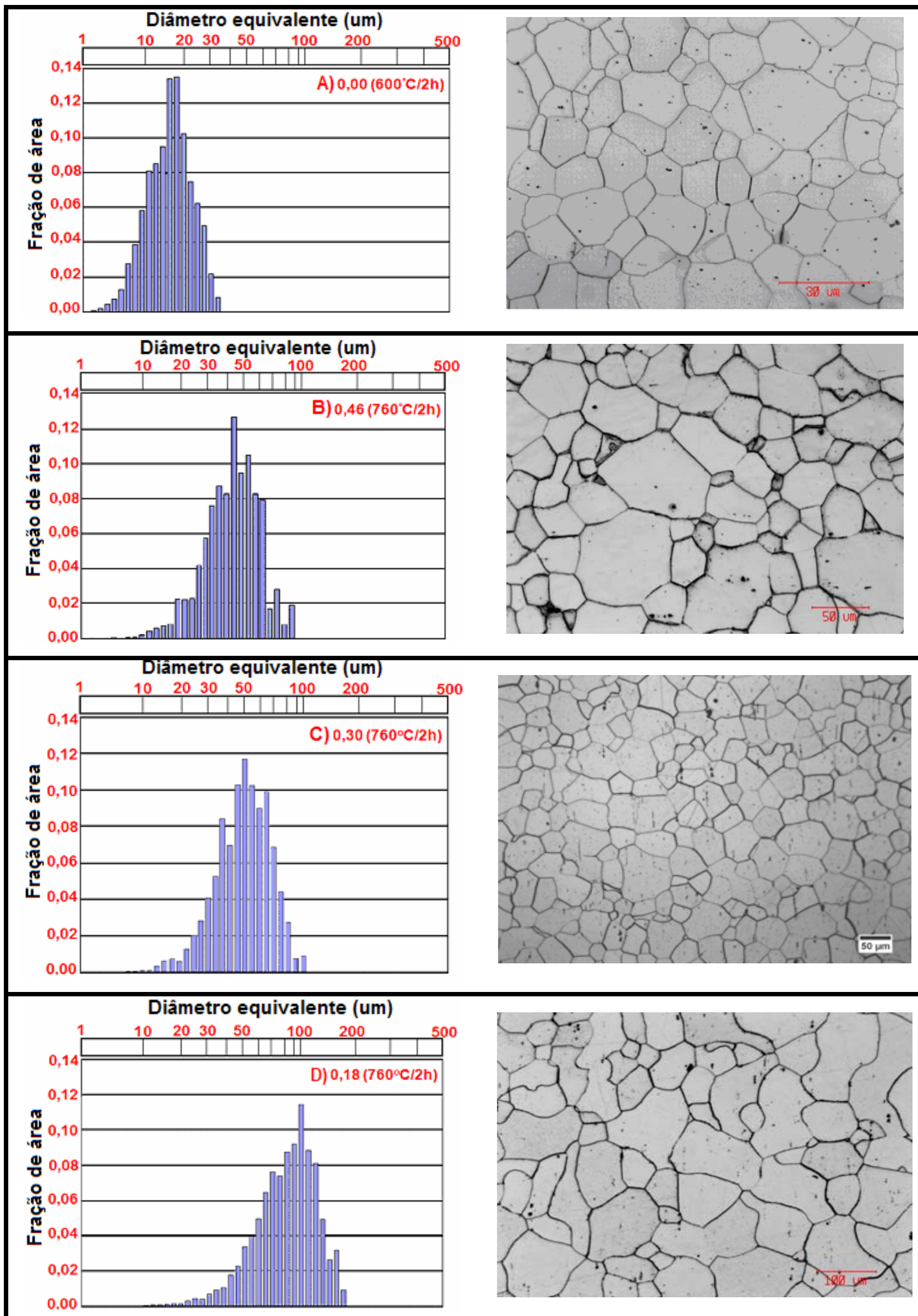

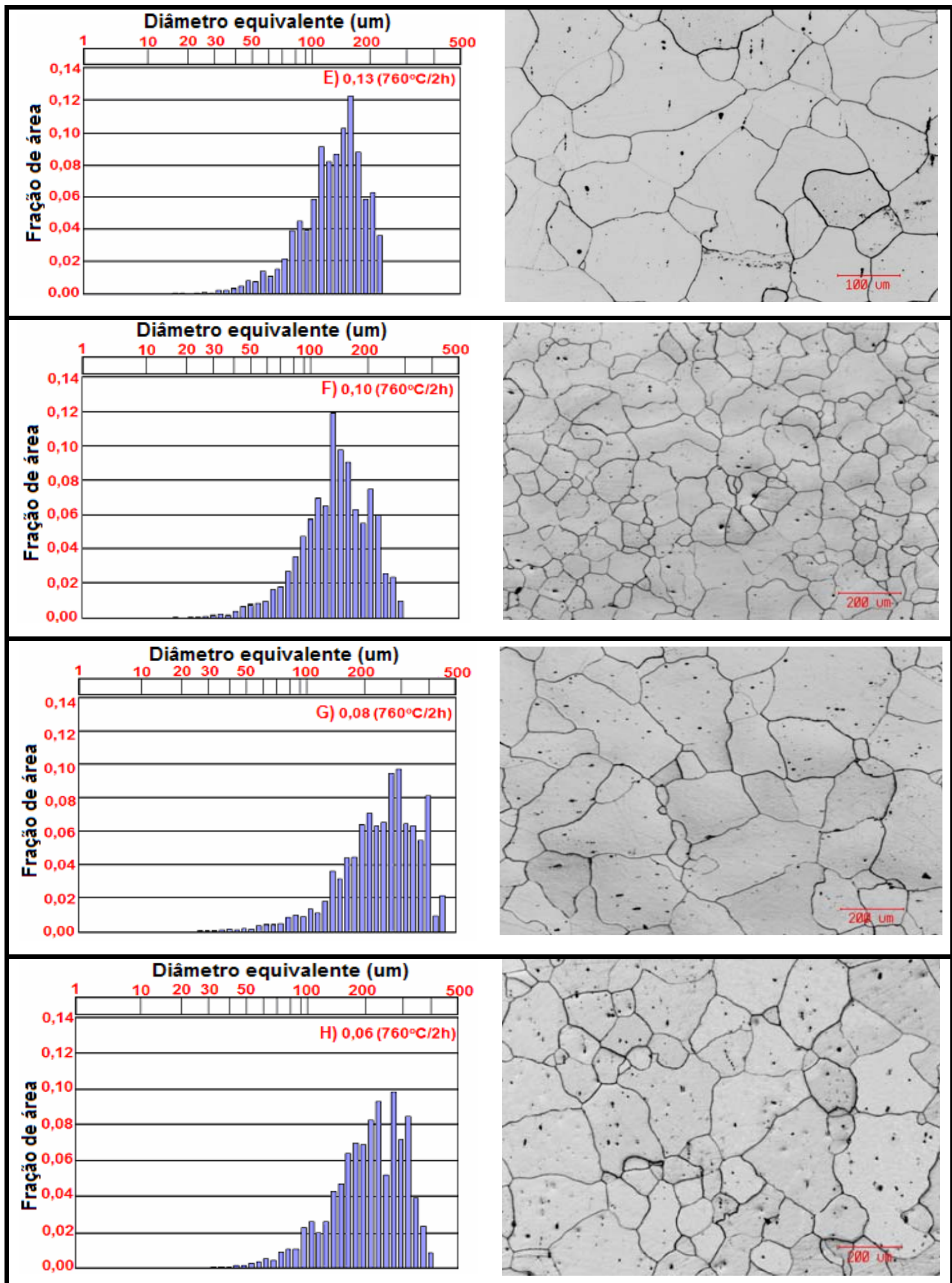

Figura 49: Gráficos com as distribuições de tamanho de grão das amostras submetidas a aumento de tamanho de grão por recristalização. 
Da Figura 49 pode-se observar que, que não há grande alteração no formato dos gráficos das distribuições quando são comparadas as amostras recristalizadas. Todas as amostras apresentam distribuição próxima de uma lognormal, porém a moda não está no centro da curva e sim ligeiramente deslocada para a direita.

É notável também que a diminuição da deformação leva a um aumento da fração de área ocupada pelas classes de grãos de maior tamanho bem como, ocorre redução da área ocupada pelos grãos menores. Assim, a redução da deformação parece se deslocar o gráfico de distribuição para a direita na direção do aumento do tamanho médio dos grãos preservando o seu formato.

Esse "deslocamento" não ocorre quando são comparadas as amostras com deformação 0,08 e 0,06. As duas amostras apresentam tamanho de grão semelhante para a classe modal. As principais diferenças entre as distribuições de tamanho, entre essas duas amostras, estão na parte mais à direita dos gráficos (classes correspondentes aos maiores grãos). O limite superior para 0 tamanho de grão, classe de tamanhos cujos grãos apresentam maior diâmetro equivalente, para deformação real de 0,08 é maior que o observado para 0,06. Comparando-se essas duas distribuições nota-se que para deformação 0,08 as classes de tamanho de grão se apresentam mais concentradas à direita indicando maior tamanho de grão recristalizado. Esse dado mostra novamente que os resultados, de maneira geral, obedecem a lei de recristalização que descreve a relação entre deformação e tamanho de grão recristalizado.

\subsubsection{Aumento do tamanho de grão por crescimento}

Observando a Figura 50 com maior atenção para a distribuição $0,00\left(600^{\circ} \mathrm{C}-2 \mathrm{~h}\right)$, que representa a distribuição de tamanho de grãos próxima a do material como recebido, é possível notar que essa amostra apresenta uma

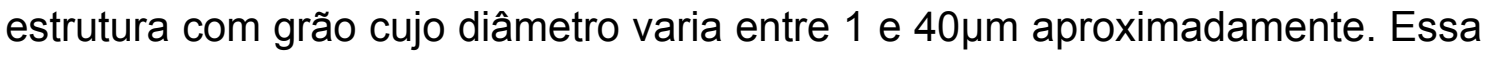
distribuição inicialmente não fornece indícios de que esse material possa apresentar crescimento anormal. Uma análise de sua microestrutura revela a presença de alguns grãos com muitos vizinhos. Esses grão podem crescer mais rapidamente durante o recozimento 

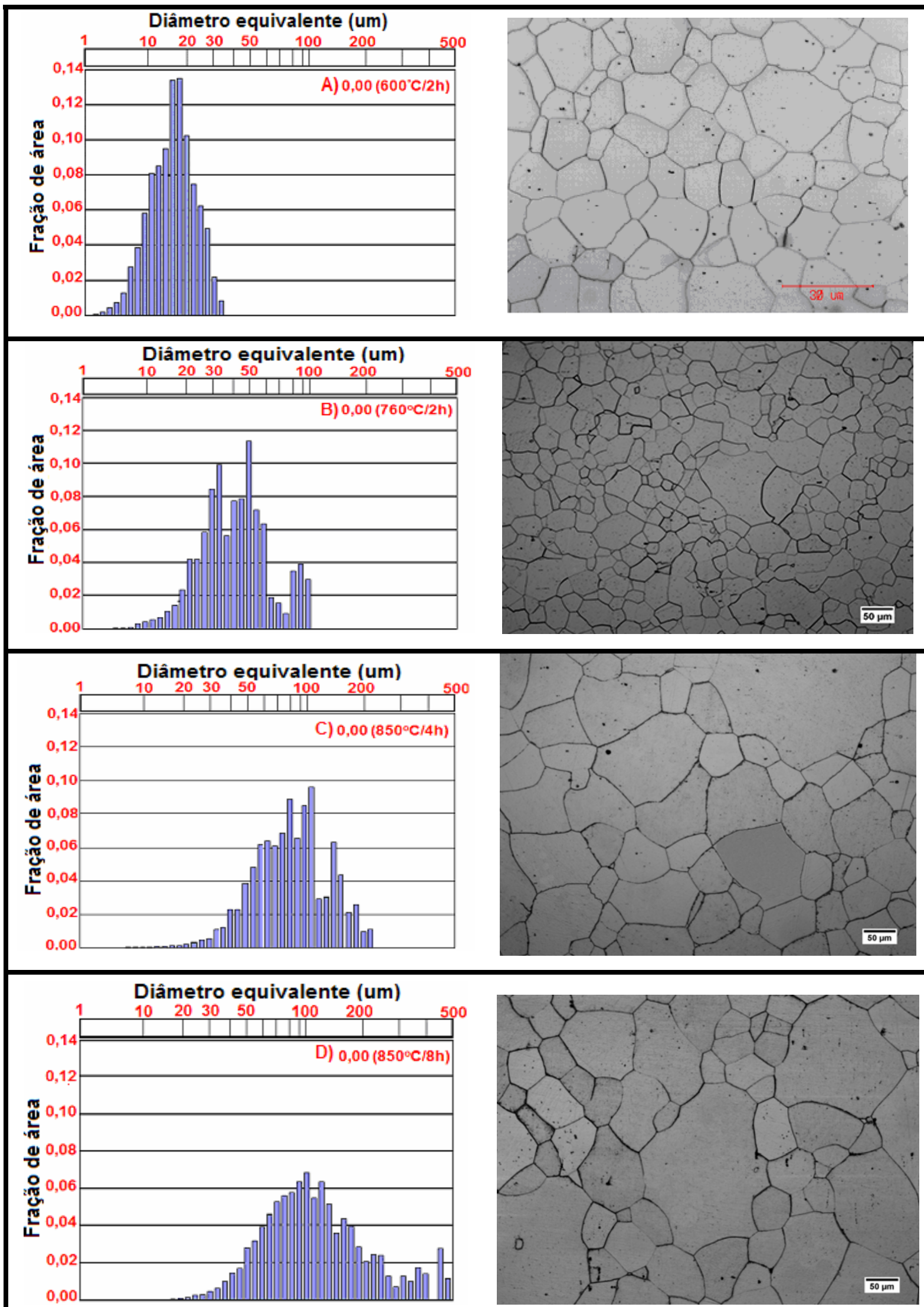

Figura 50: Gráficos com as distribuições de tamanho de grão das amostras submetidas a aumento de tamanho de grão por crescimento. 
As demais distribuições indicam crescimento anormal dos grãos com distribuição bimodal dos TGs, conforme relata a distribuição mostrada na Figura 50 identificado por $0,00\left(760^{\circ} \mathrm{C} / 2 \mathrm{~h}\right)$. Para essa amostra a distribuição fugiu completamente de uma log-normal. A presença de colônias de grãos grande é descrito por Padilha [17] como um fator que pode provocar crescimento anormal de grãos. As amostras submetidas à deformação e posterior tratamento térmico possuem distribuição próxima a uma log-normal. Outro fator que explica o crescimento anormal de grãos é a presença de grãos com muitos lados (já citada anteriormente) conforme indica a Figura 51. Segundo Shewmon [62], grãos com muitos lados crescem durante recozimento consumindo grãos menores ocasionando crescimento anormal.

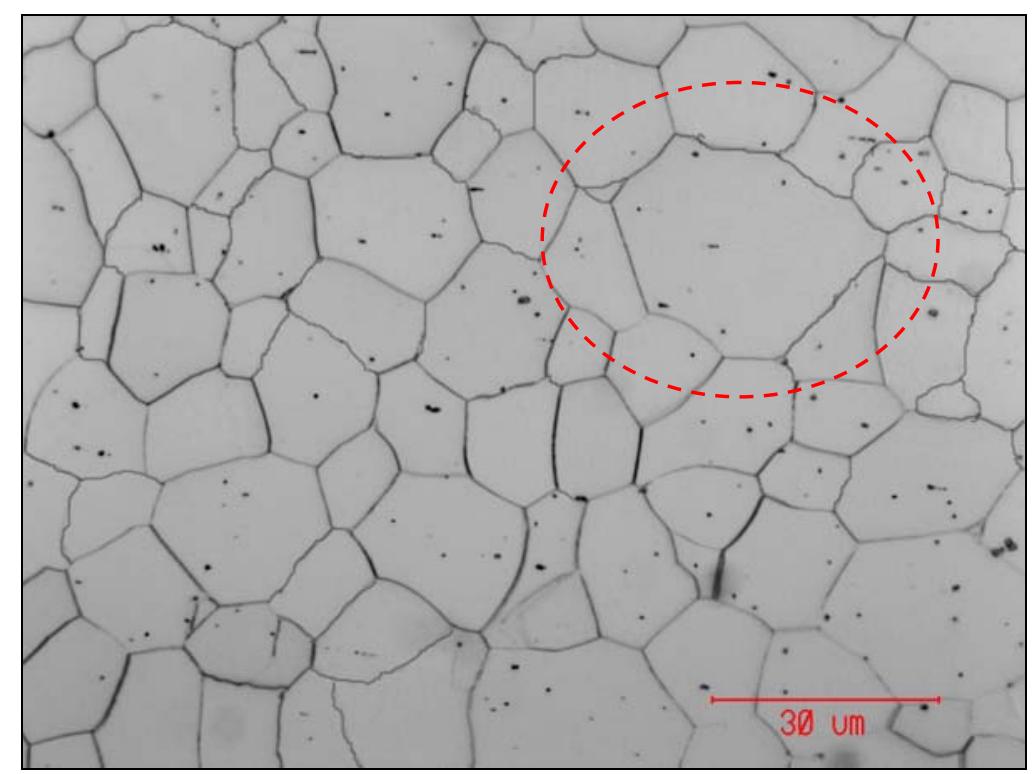

Figura 51: Micrografia ilustrando a estrutura de grãos em uma amostra recozida a $600^{\circ} \mathrm{C}$ por duas horas. Em destaque, um grão grande contendo 10 lados.

A Figura 52 retrata a estrutura de grãos de uma amostra que sofreu aumento de tamanho de grão por crescimento. Nota-se no canto inferior esquerdo da figura, um grão de tamanho e número de lados superior aos demais. Tal fato explica a distribuição de tamanho de grãos bimodal caracterizando crescimento anormal. 


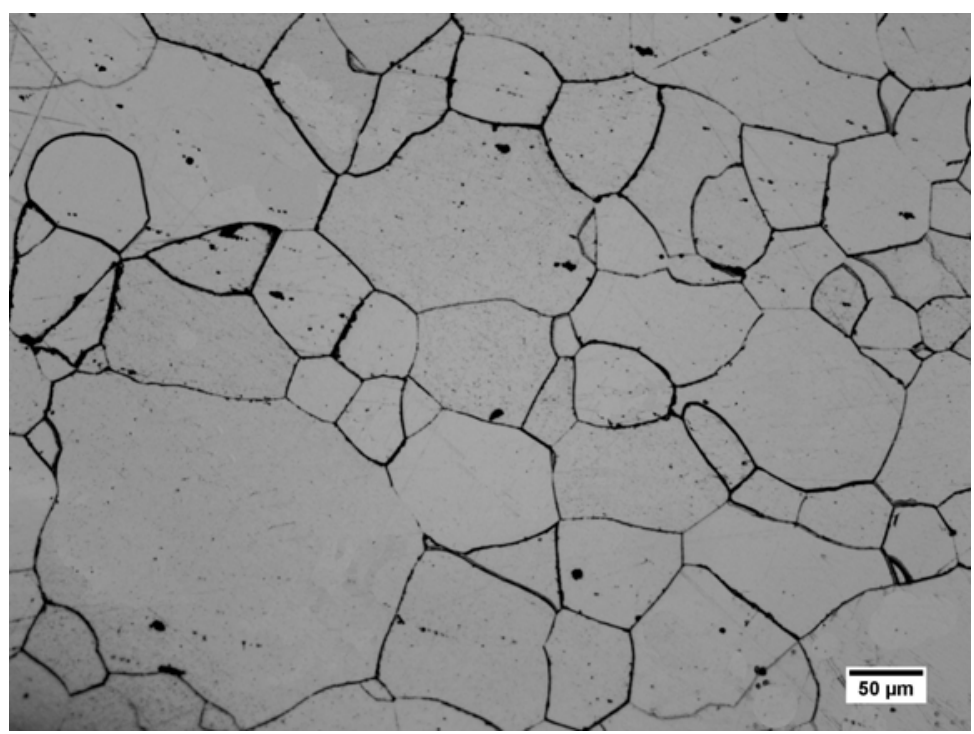

Figura 52: Micrografia de amostra submetida á crescimento de grãos por tratamento térmico a $850^{\circ} \mathrm{C}$ por oito horas.

A Tabela 5 relaciona os resultados das medições de tamanho de grão comparando os valores obtidos pelo método dos interceptos e pelo método das áreas. Nota-se que o valor médio ponderado pela fração de área é sempre maior que o do intercepto. Os valores apresentados mostram que a razão $\mathrm{l} / \mathrm{dA}$ é aproximadamente 0,60 havendo pequena variação em torno desse valor. Dessa forma, há um claro indício de uma relação de proporcionalidade entre essas medidas mesmo tomando-se dois diferentes métodos de aumento de tamanho de grãos. A exceção a essa proporcionalidade fica por conta da amostra Embraco - 850C 8h que apresenta razão $\ell / d A$ igual a 0,49.

Tabela 5: Comparação entre os resultados das medições de tamanho de grão pelos métodos dos interceptos e das áreas.

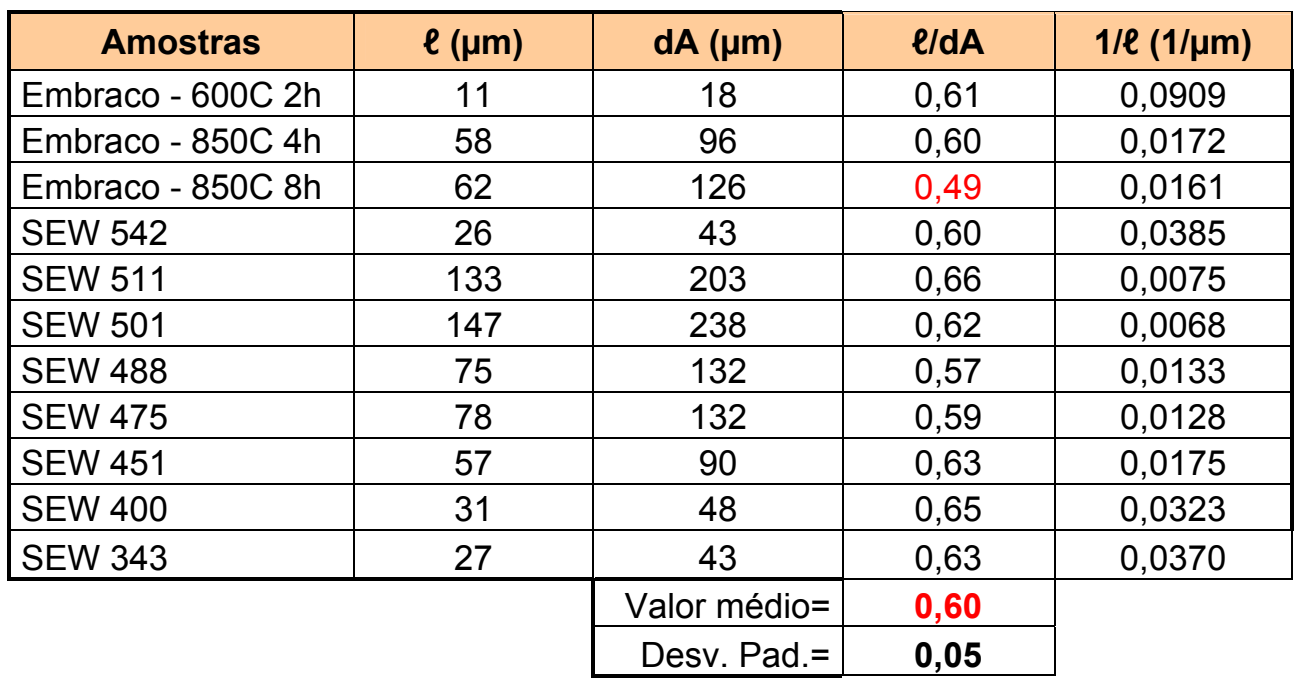




\subsection{Comparação entre os resultados de caracterização magnética obti- dos no IPT e Inmetro.}

A fim de garantir maior confiabilidade e verificar a precisão do método utilizado na caracterização magnética para os ensaios quase-estáticos, foram comparados os ciclos de histereses e campos coercivos da amostras SEW 540, SEW 400 e SEW 343 produzidas por recristalização. Os resultados comparativos são mostrados a seguir.

Uma comparação entre as histereses para a amostra SEW 540 é dada na Figura 53. Nota-se que a curva produzida no IPT é ligeiramente inclinada com relação ao ciclo obtido no Inmetro. Tal fato provavelmente se deve à curvatura presente nessa amostra. Esse abaulamento dificulta o posicionamento das chapas no interior das bobinas do quadro de Epstein provocando tensões elásticas na amostra em função do pequeno espaço no interior das bobinas.

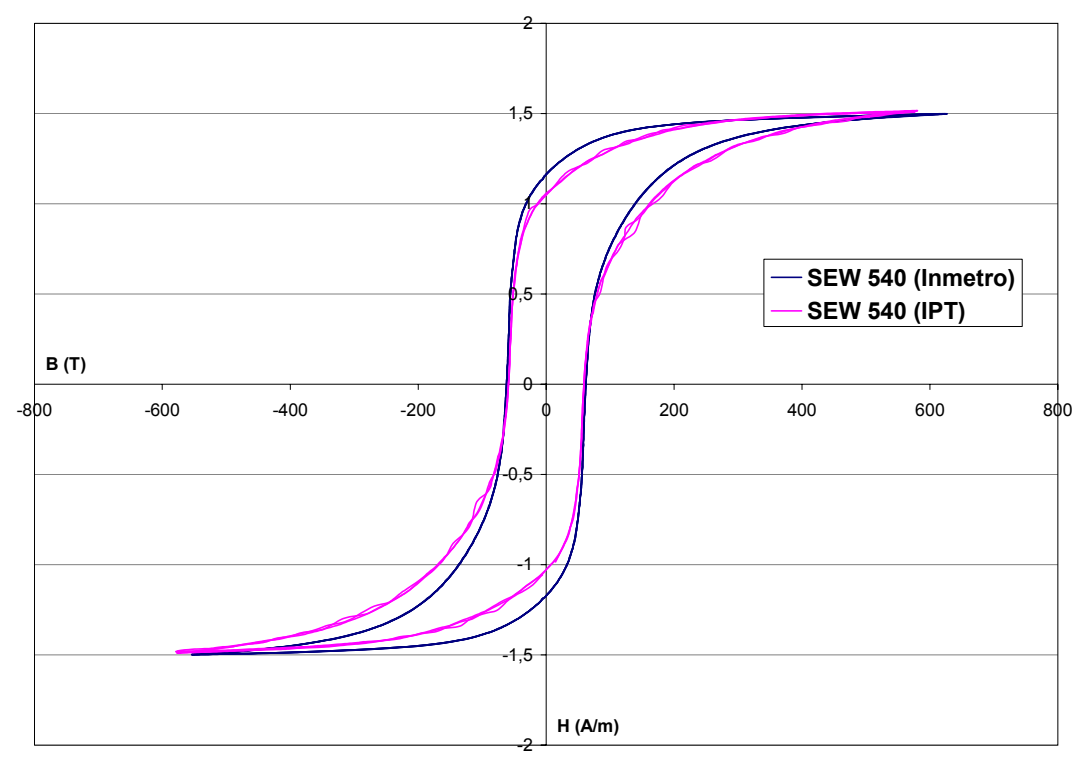

Figura 53: Comparação entre as histereses obtidas no IPT e no Inmetro para indução máxima de 1,5T no regime quase estático para a amostra SEW 540.

Bastante semelhança entre as histereses para as amostras SEW 400 e SEW 343 pode ser vista através da Figura 54 e Figura 55, respectivamente. 


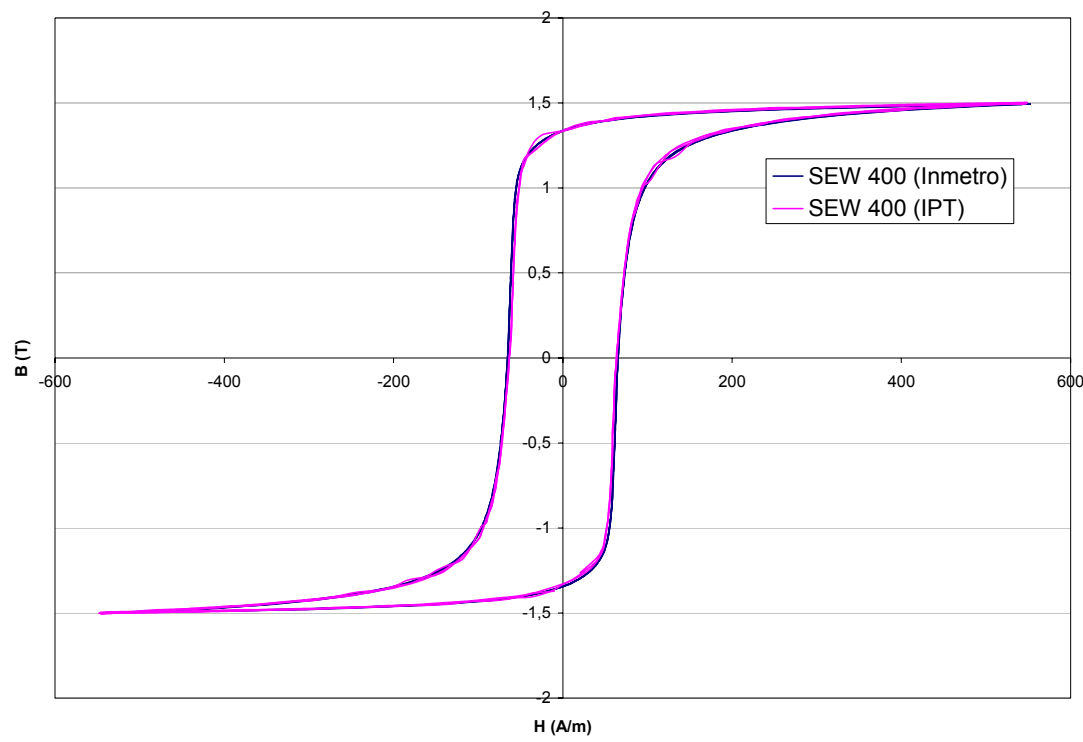

Figura 54: Comparação entre as histereses obtidas no IPT e no Inmetro para indução máxima de 1,5T no regime quase estático para a amostra SEW 400.

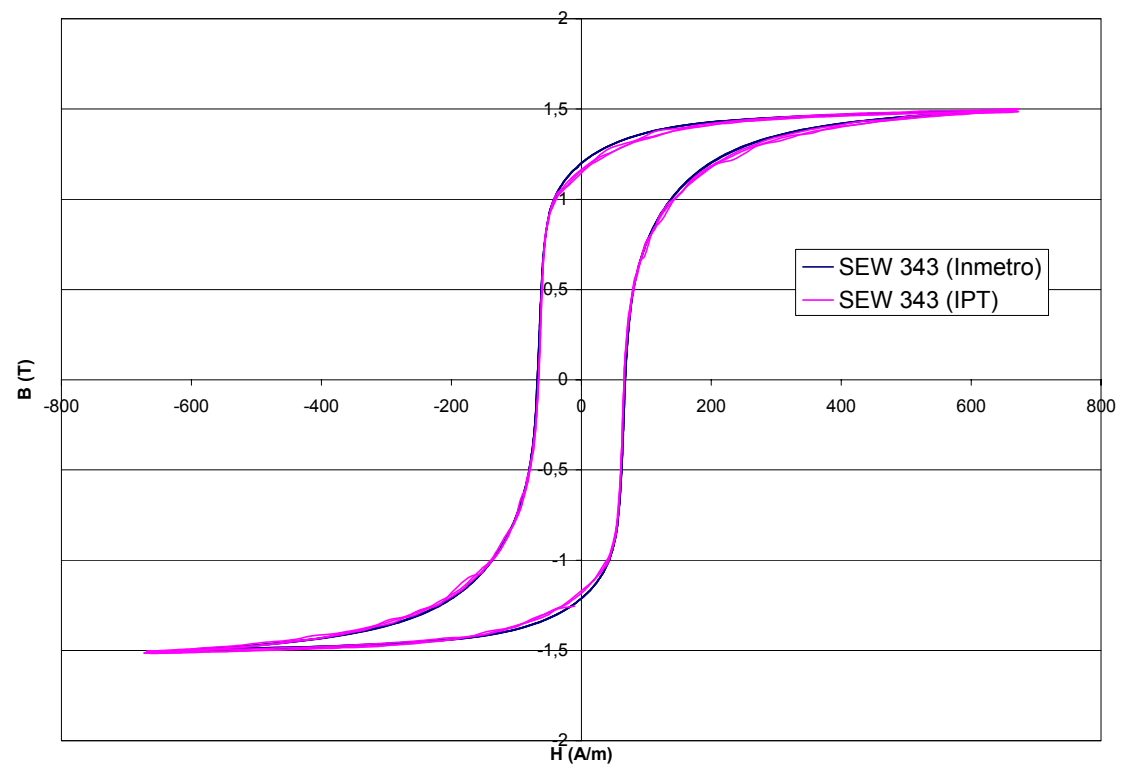

Figura 55: Comparação entre as histereses obtidas no IPT e no Inmetro para indução máxima de 1,5T no regime quase estático para a amostra SEW 400.

Com relação ao campo coercivo os valores são bastante semelhantes conforme indica a Tabela 6 . Diante desses dados pode-se concluir que os resultados são compatíveis. 
Tabela 6: Valores de campo coercivo e energia dissipada por histerese para as amostras analisadas no Inmetro e no IPT.

\begin{tabular}{|l|c|c|c|c|c|c|}
\cline { 2 - 7 } \multicolumn{1}{c|}{} & \multicolumn{2}{c|}{ SEW 540 } & \multicolumn{2}{c|}{ SEW 400 } & \multicolumn{2}{c|}{ SEW 400 } \\
\cline { 2 - 7 } \multicolumn{1}{c|}{} & $\mathbf{H c}(\mathbf{A} / \mathbf{m})$ & $\mathbf{W h}\left(\mathbf{J}^{\prime} \mathbf{m}^{3}\right)$ & $\mathbf{H c}(\mathbf{A} / \mathbf{m})$ & $\mathbf{W h}\left(\mathbf{J} / \mathbf{m}^{3}\right)$ & Hc (A/m) & Wh $\left(\mathbf{J} / \mathbf{m}^{3}\right)$ \\
\hline Imetro & 61,8 & 456,69 & 61,81 & 446,06 & 67,65 & 487,18 \\
\hline IPT & 60 & 451,43 & 59,91 & 433,14 & 67,14 & 484,5 \\
\hline Diferença (\%) & 3,16 & 1,17 & 3,16 & 2,98 & 0,7 & 0,55 \\
\hline
\end{tabular}

\subsection{O efeito do tamanho de grão sobre a indução $B_{50}$}

As tabelas a seguir listam os valores de $B_{50}$ para as amostras com diferentes tamanhos de grão. Esses dados estão divididos em grupos de acordo com o procedimento usado para proporcionar aumento do tamanho de grão. A Tabela 7 traz o $B_{50}$ do material submetido a alívio de tensões (aqui chamada de Embraco $\left.600^{\circ} \mathrm{C} 2 \mathrm{~h}\right)$.

Tabela 7: $\mathrm{B}_{50}$ da amostra submetida a alívio de tensões

\begin{tabular}{|c|c|}
\hline \multicolumn{2}{|c|}{ Alívio de tensões } \\
\hline Amostras & B50 (T) \\
\hline Embraco $-600^{\circ} \mathrm{C} 2 \mathrm{~h}$ & 1,7437 \\
\hline
\end{tabular}

A indução $B_{50}$ para as amostras recristalizadas é listada na Tabela 8 e na Tabela 9 estão dispostos os valores para as amostras que sofreram crescimento de grãos.

Tabela 8: $\mathrm{B}_{50}$ das amostras submetidas a aumento de TG por recristalização.

\begin{tabular}{|c|c|}
\hline \multicolumn{2}{|c|}{ Aumento do TG por recristalização } \\
\hline Amostras & B50 (T) \\
\hline SEW 511 & 1,7168 \\
\hline SEW 501 & 1,7229 \\
\hline SEW 488 & 1,7212 \\
\hline SEW 475 & 1,7328 \\
\hline SEW 451 & 1,7236 \\
\hline SEW 400 & 1,7231 \\
\hline SEW 343 & 1,7222 \\
\hline valor médio $=$ & 1,7232 \\
\hline
\end{tabular}


Tabela 9: $\mathrm{B}_{50}$ das amostras submetidas a aumento de $\mathrm{Tg}$ por crescimento de grãos.

\begin{tabular}{|l|c|}
\hline \multicolumn{2}{|c|}{ Aumento do TG por crescimento } \\
\hline Amostras & B50 (T) \\
\hline SEW - 760C $2 \mathrm{~h}$ & 1,7484 \\
\hline Embraco - 850C 4h & 1,7585 \\
\hline Embraco - 850C 8h & 1,7561 \\
\hline valor médio $=$ & $\mathbf{1 , 7 5 4 4}$ \\
\hline
\end{tabular}

Tomando-se por base a amostra submetida a recozimento para alívio de tensões avalia-se que os dois procedimentos utilizados para provocar aumento do tamanho de grão tiveram efeito diferente sobre a textura do material. Enquanto o aumento do TG por crescimento elevou os valores de $B_{50}$, o aumento do TG por recristalização provocou queda desse indicador. Sendo o $B_{50}$ uma propriedade magnética fortemente dependente da textura, é possível afirmar que, para essas amostras, o processo de recristalização de alguma forma resultou em menor quantidade de grãos orientados favoravelmente à magnetização, quando aplicado campo magnético paralelo à direção de laminação.

\subsection{O efeito do tamanho de grão sobre o campo coercivo}

O efeito do tamanho de grão sobre o campo coercivo, medido em ensaio no quadro de Epstein em regime quase-estático $(5 \mathrm{mHz})$ para as induções máximas de 1,0 e 1,5T, é ilustrado na Figura 56 e na Figura 57 . Elas trazem gráficos demonstrando o comportamento do campo coercivo $(\mathrm{Hc})$ em função do inverso do tamanho de grão (1/l) e do inverso da raiz do tamanho de grão $(1 / \sqrt{ } \ell)$, respectivamente. 


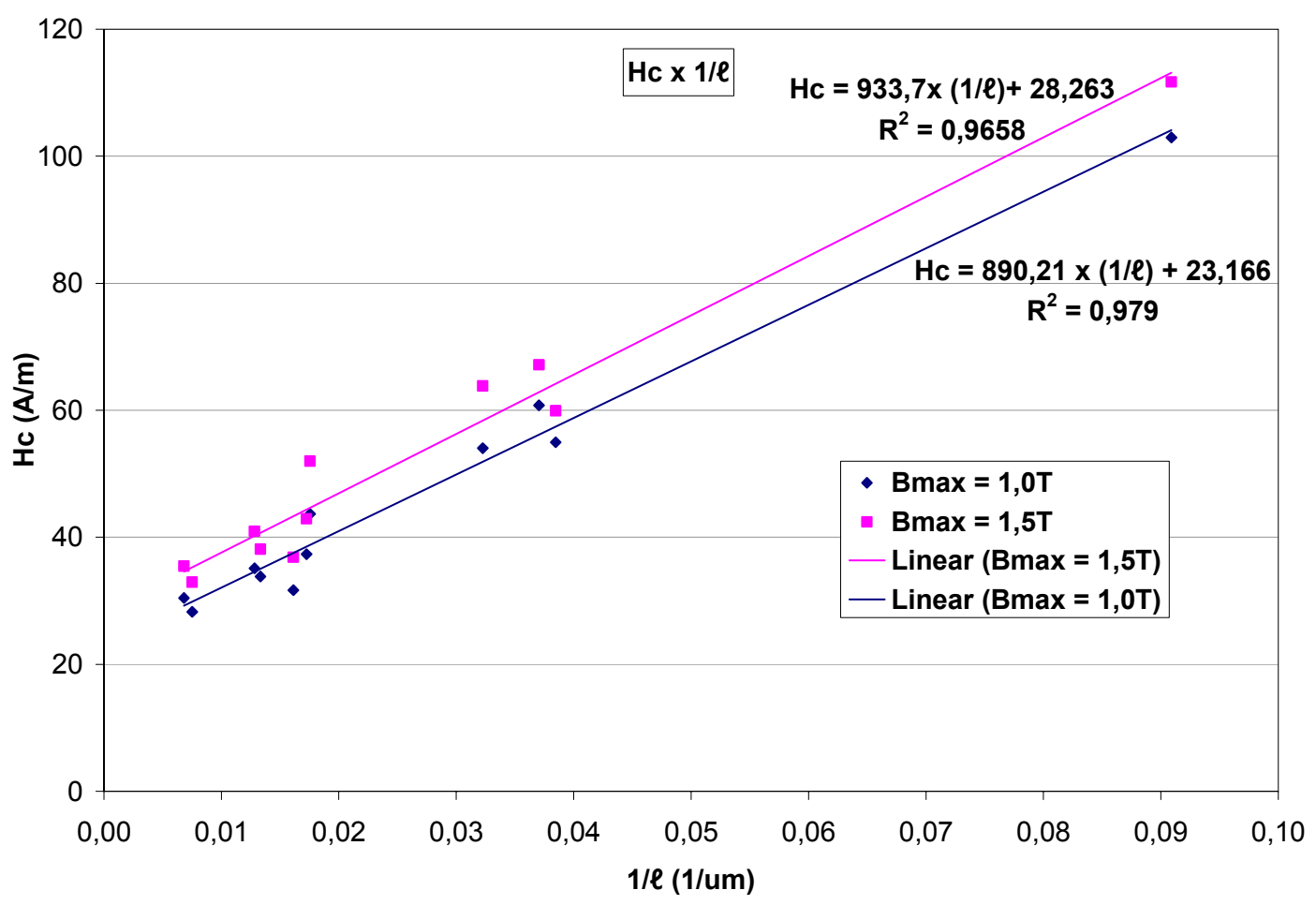

Figura 56: Gráfico mostrando o comportamento do campo coercivo $\mathrm{Hc}$ em função do inverso do tamanho de grão (1/l).

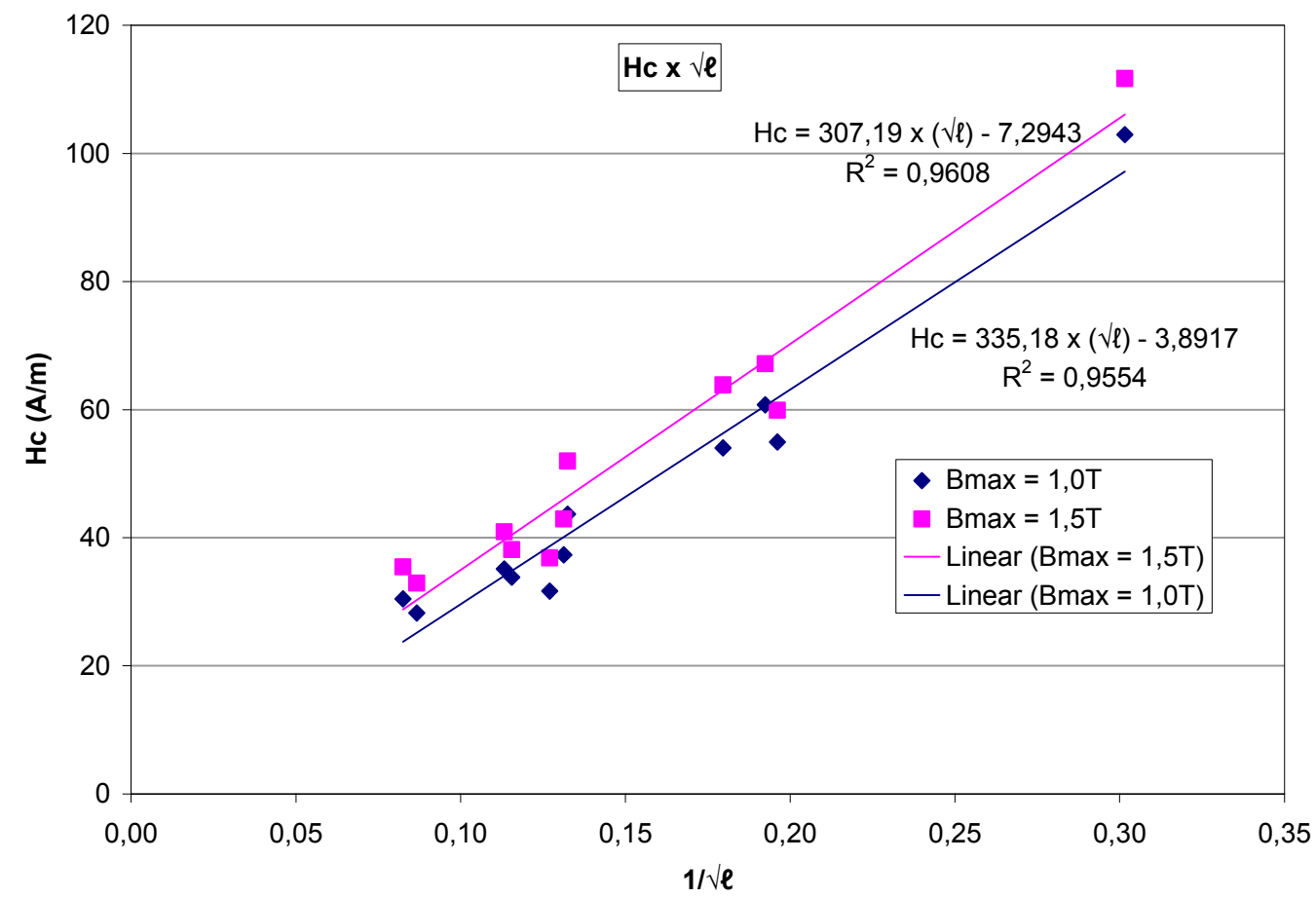

Figura 57: Gráfico do campo coercivo $(\mathrm{Hc})$ em função do inverso da raiz do tamanho de grão.

Nos dois casos, retas podem ser ajustadas sobre os pontos experimentais. A efetividade do ajuste, dado pelo coeficiente de determinação $\left(R^{2}\right)$, que 
para as duas leis de dependência demonstrou-se bastante semelhante, porém ligeiramente superior em favor da lei Hcœ1/l para os dois valores de indução.

A Tabela 10 lista as equações do ajuste linear e os coeficientes de determinação para as duas leis de dependência nas induções 1 e 1,5T. Uma comparação entre os valores de $\mathrm{R}^{2}$ nos diz que o favoritismo de da lei $\mathrm{Hc} \propto 1 / \ell$ é mais pronunciado para a indução Bmax $=1 \mathrm{~T}$ ao passo que para Bmax $=1,5 \mathrm{~T}$ a diferença de $R^{2}$ entre as duas leis e dependência é muito pequena $(0,005)$. Portanto, pode-se dizer que a lei $H c \propto 1 / \sqrt{ } \ell$ ganha força para altas induções porém a 1,5T o comportamento do campo coercivo ainda é melhor descrito como variando linearmente com o inverso do tamanho de grão contrariando Bertotti [46].

Tabela 10: Equações das retas e coeficientes de determinação provenientes do ajuste linear dos gráficos $\mathrm{Hc} \times 1 / \ell$ e Hc $\times 1 / \sqrt{ } \ell$ para as induções de 1,0 e 1,5T.

\begin{tabular}{|c|c|c|c|c|}
\cline { 2 - 5 } \multicolumn{1}{c|}{} & \multicolumn{2}{c|}{ Bmax =1,0T } & \multicolumn{2}{c|}{ Bmax =1,5T } \\
\cline { 2 - 5 } \multicolumn{1}{c|}{ Equação da reta } & $\mathbf{R}^{\mathbf{2}}$ & Equação da reta & $\mathbf{R}^{\mathbf{2}}$ \\
\hline $\mathbf{1} / \ell$ & $\mathrm{Hc}=890,21 \times 1 / \ell+23,166$ & 0,9790 & $\mathrm{Hc}=933,70 \times 1 / \ell+28,263$ & $\mathbf{0 , 9 6 5 8}$ \\
\hline $\mathbf{1} / \sqrt{ } \boldsymbol{\ell}$ & $\mathrm{Hc}=342,91 \times(1 / \sqrt{ } \ell)-2,4252$ & 0,9562 & $\mathrm{Hc}=307,19 \times(1 / \sqrt{ } \ell)-7,2943$ & $\mathbf{0 , 9 6 0 8}$ \\
\hline
\end{tabular}

Outra evidência da maior confiabilidade da lei de dependência Hcœ1/l é o fato de as retas de ajuste para uma relação de proporcionalidade com o inverso da raiz do tamanho de grão apresentarem coeficientes lineares negativos. Esses coeficientes contrariam qualquer resultado já obtido anteriormente.

Uma comparação entre os resultados da caracterização magnética a 1,0 e $1,5 \mathrm{~T}$ e os resultados experimentais encontrados na literatura é dada pela Figura 58, onde os resultados publicados por Yensen e são confrontados com as curvas Hc x 1/l para 1,0 e 1,5T. Por uma questão de adequação entre unidade de medida o tamanho de grãos $\ell$ nessa figura é dado em milímetros.

A Figura 58 mostra que o coeficiente angular obtido experimentalmente neste trabalho é bem diferente dos citados por Yensen e Degauque 1 (retas obtidas para maiores valores de tamanho de grão), porém se aproxima de Degauque 2 . 


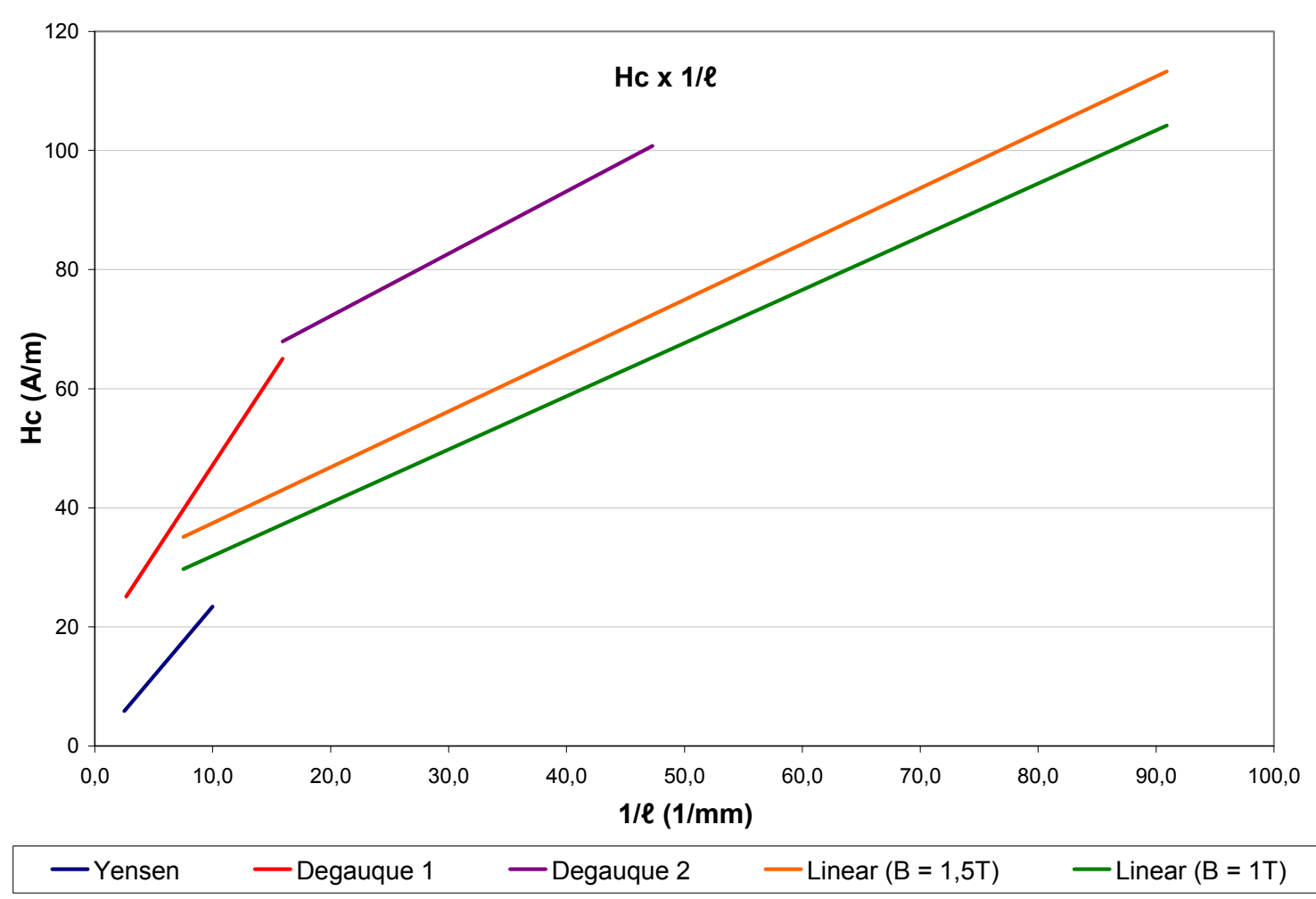

Figura 58: Gráfico Hc x 1/l onde são mostrados os resultados da caracterização magnética, dados pelas linhas Linear $(B=1 T)$ e Linear $(B=1,5 T)$, e os resultados obtidos por Yensen e Degauque.

A Figura 59 traz retas $\mathrm{Hc} \times 1 / \ell$. A primeira reta, Linear $(\mathrm{Bmax}=1 \mathrm{~T})$, foi construída a partir dos resultados oriundos do procedimento experimental. As outras duas retas, Mager 1T e Yensen, foram construídas a partir da equação proposta por Mager e dos resultados publicados por Yensen, respectivamente.

Como a teoria de Mager não prevê nenhum efeito da indução máxima na relação entre campo coercivo e tamanho de grão e Yensen trabalhou com indução máxima de 1T, apenas os resultados para indução de 1T foram colocados na figura. Deve-se notar que as retas de Mager e Yensen concordam com relação ao coeficiente angular embora tratem de faixas diferentes de tamanhos de grão. O mesmo não pode ser dito para Linear. Os motivos que levam a tão grande diferença de inclinações são desconhecidos. 


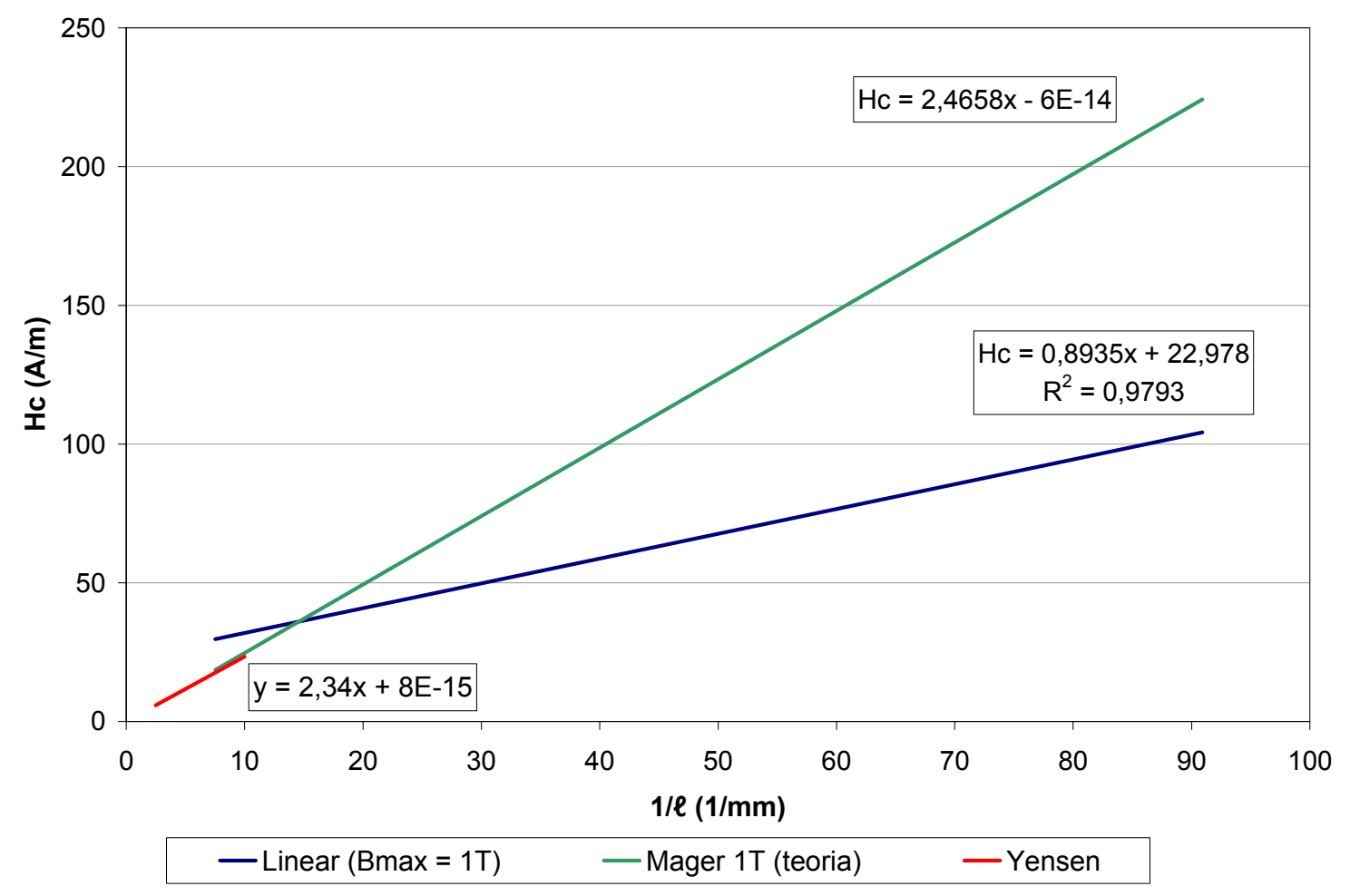

Figura 59: Gráfico indicando as retas $\mathrm{Hc} \times 1 / \ell$ obtida por Yensen, calculada a partir da expressão proposta por Mager e a construída a partir dos resultados experimentais.

Para as demais induções máximas também foi verificado crescimento linear do campo coercivo com o inverso do tamanho de grão conforme ilustram os pontos experimentais no gráfico da Figura 60 e as linhas de tendência no gráfico da Figura 61. 


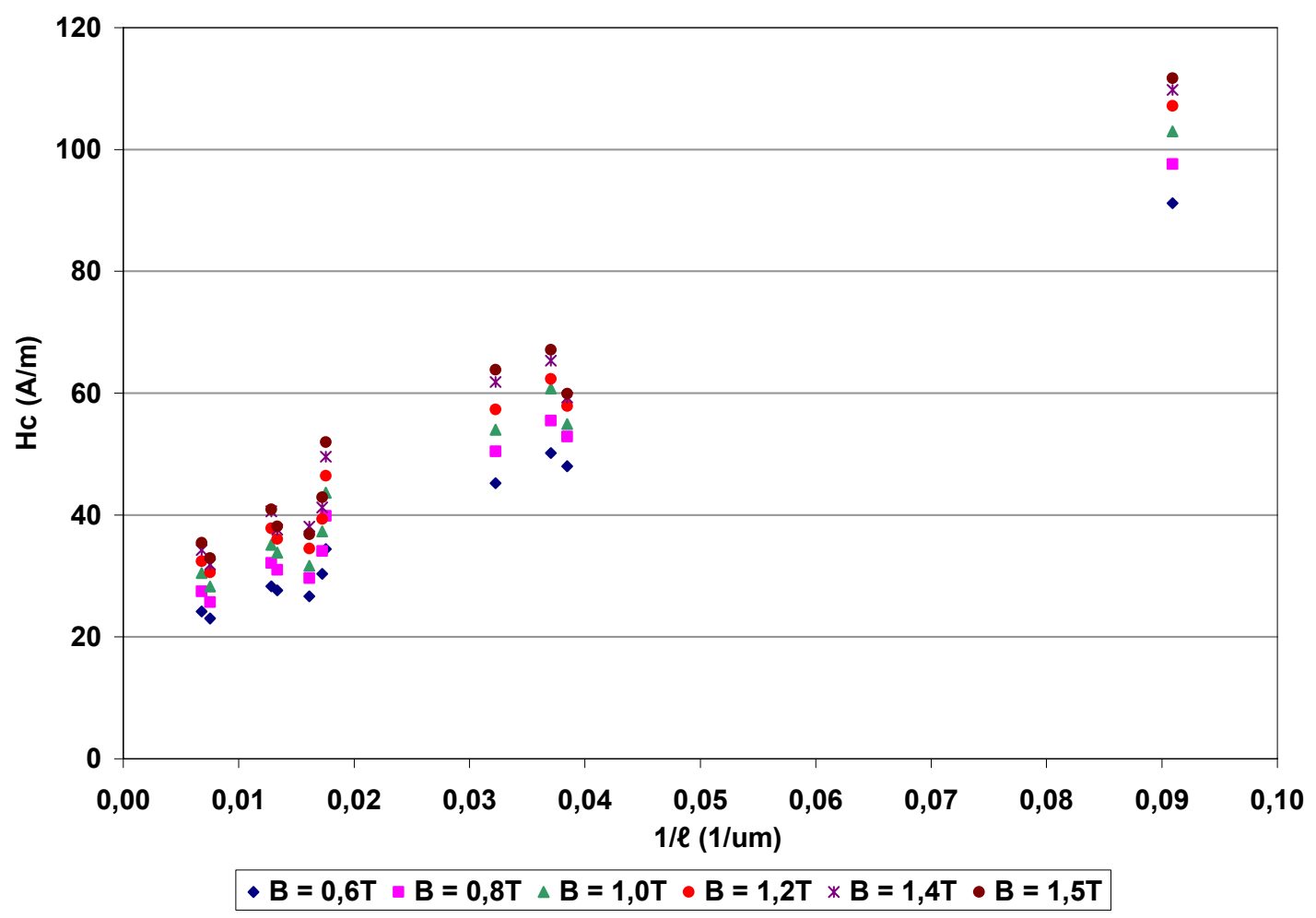

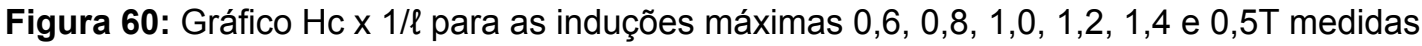
em ensaio quase estático.

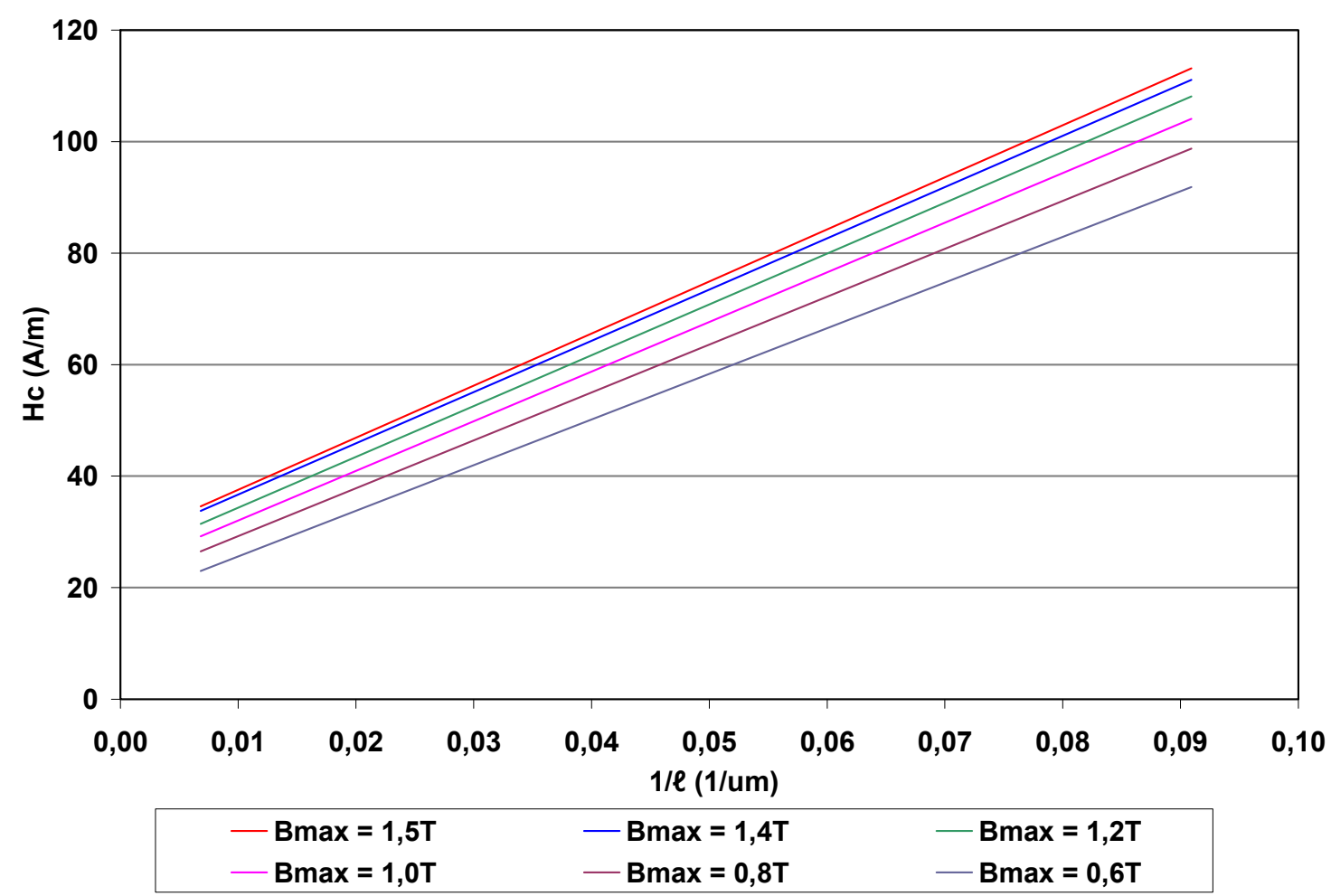

Figura 61: Linhas de tendência para o gráfico $\mathrm{Hc} \times 1 / \ell$ para diversas induções indicando uma dependência linear. 
Os dados referentes aos coeficientes lineares (a) e angular (b) e índice de determinação $\left(R^{2}\right)$ das retas do gráfico da Figura 61 assim como os mesmos coeficientes para uma dependência linear $\mathrm{Hc} \propto 1 / \sqrt{ } \ell$ estão listados na Tabela 11.

Tabela 11: Valores dos coeficientes linear e angular e índice de determinação para o ajuste linear dos gráficos $\mathrm{Hc} \propto 1 / \ell$ e $\mathrm{Hc} \propto 1 / \sqrt{ } \ell$.

\begin{tabular}{|c|c|c|c|c|c|c|}
\cline { 2 - 7 } \multicolumn{1}{c|}{} & \multicolumn{3}{c|}{ Hc= a+b.(1/l) } & \multicolumn{3}{c|}{ Hc = a+b.(1/ $\mathbf{l})$} \\
\cline { 2 - 7 } \multicolumn{1}{c|}{} & $\mathbf{a}$ & $\mathbf{b}$ & $\mathbf{R}^{\mathbf{2}}$ & $\mathbf{a}$ & $\mathbf{b}$ & $\mathbf{R}^{\mathbf{2}}$ \\
\hline $\mathrm{B} \max =0,6 \mathrm{~T}$ & 17,432 & 818,56 & $\mathbf{0 , 9 9 1 0}$ & $-0,2850$ & 352,68 & $\mathbf{0 , 9 4 8 6}$ \\
\hline $\mathrm{Bmax}=0,8 \mathrm{~T}$ & 20,660 & 858,99 & $\mathbf{0 , 9 8 5 7}$ & $-0,5414$ & 347,06 & $\mathbf{0 , 9 5 7 7}$ \\
\hline $\mathrm{B} \max =1,0 \mathrm{~T}$ & 23,166 & 890,21 & $\mathbf{0 , 9 7 9 0}$ & $-2,4252$ & 342,91 & $\mathbf{0 , 9 5 6 2}$ \\
\hline $\mathrm{B} \max =1,2 \mathrm{~T}$ & 25,235 & 911,54 & $\mathbf{0 , 9 8 1 6}$ & $-3,8917$ & 335,18 & $\mathbf{0 , 9 5 5 4}$ \\
\hline $\mathrm{B} \max =1,4 \mathrm{~T}$ & 27,543 & 919,16 & $\mathbf{0 , 9 7 5 9}$ & $-5,4546$ & 323,47 & $\mathbf{0 , 9 6 2 2}$ \\
\hline $\mathrm{B} \max =1,5 \mathrm{~T}$ & 28,263 & 933,70 & $\mathbf{0 , 9 6 5 8}$ & $-7,2943$ & 307,19 & $\mathbf{0 , 9 6 0 8}$ \\
\hline
\end{tabular}

Uma análise dos coeficientes angulares das retas para a lei $\mathrm{Hc} \propto 1 / \ell$ revela aumento desse coeficiente com a indução máxima. Pode-se notar também que esse ritmo de crescimento diminui com o aumento da indução. Essas informações podem ser vistas em forma de gráfico na Figura 62. 


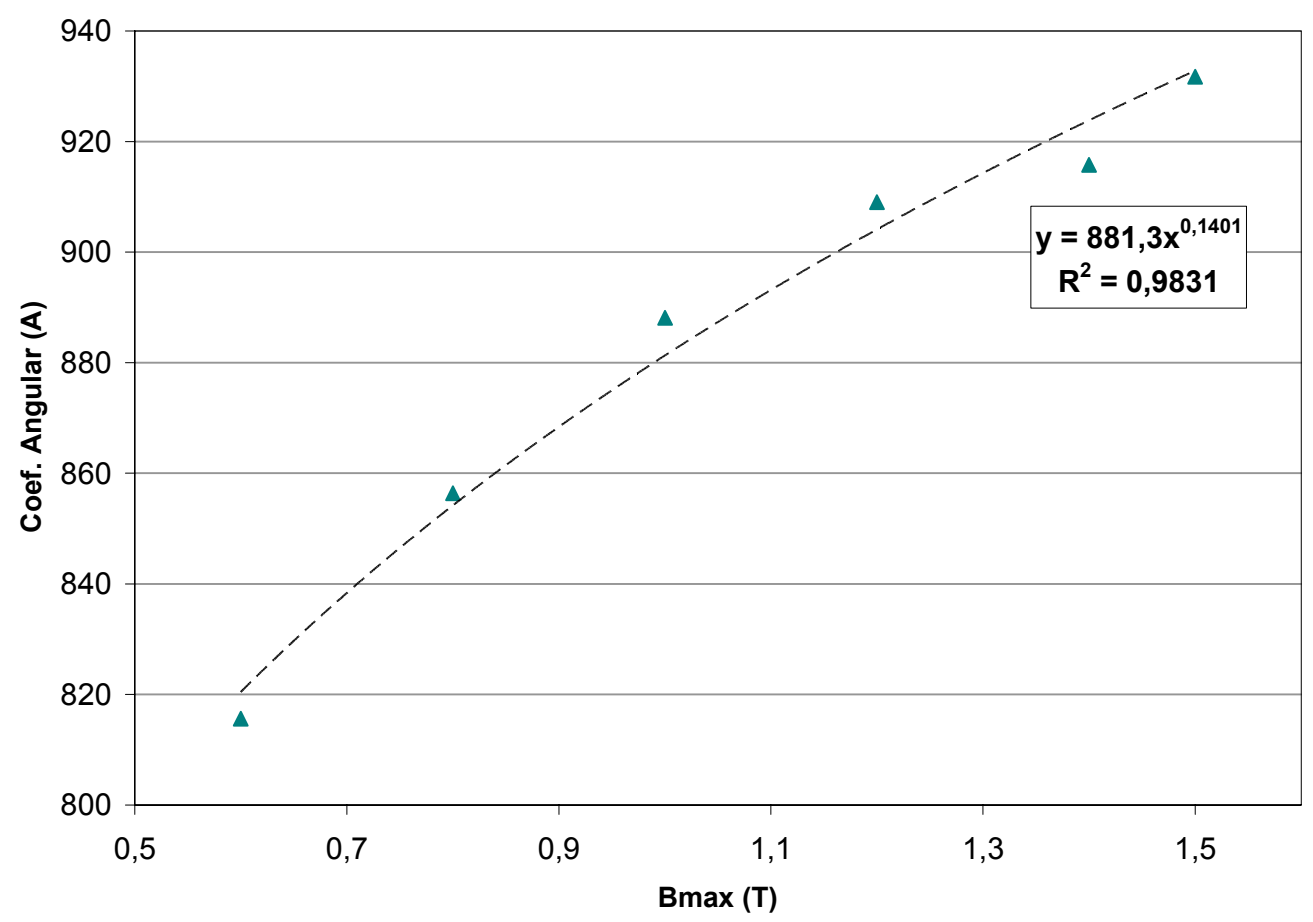

Figura 62: Gráfico do coeficiente angular da reta Hc x 1/l em função da indução máxima.

Também o coeficiente linear apresenta dependência logarítmica com a indução máxima como mostra a Figura 63.

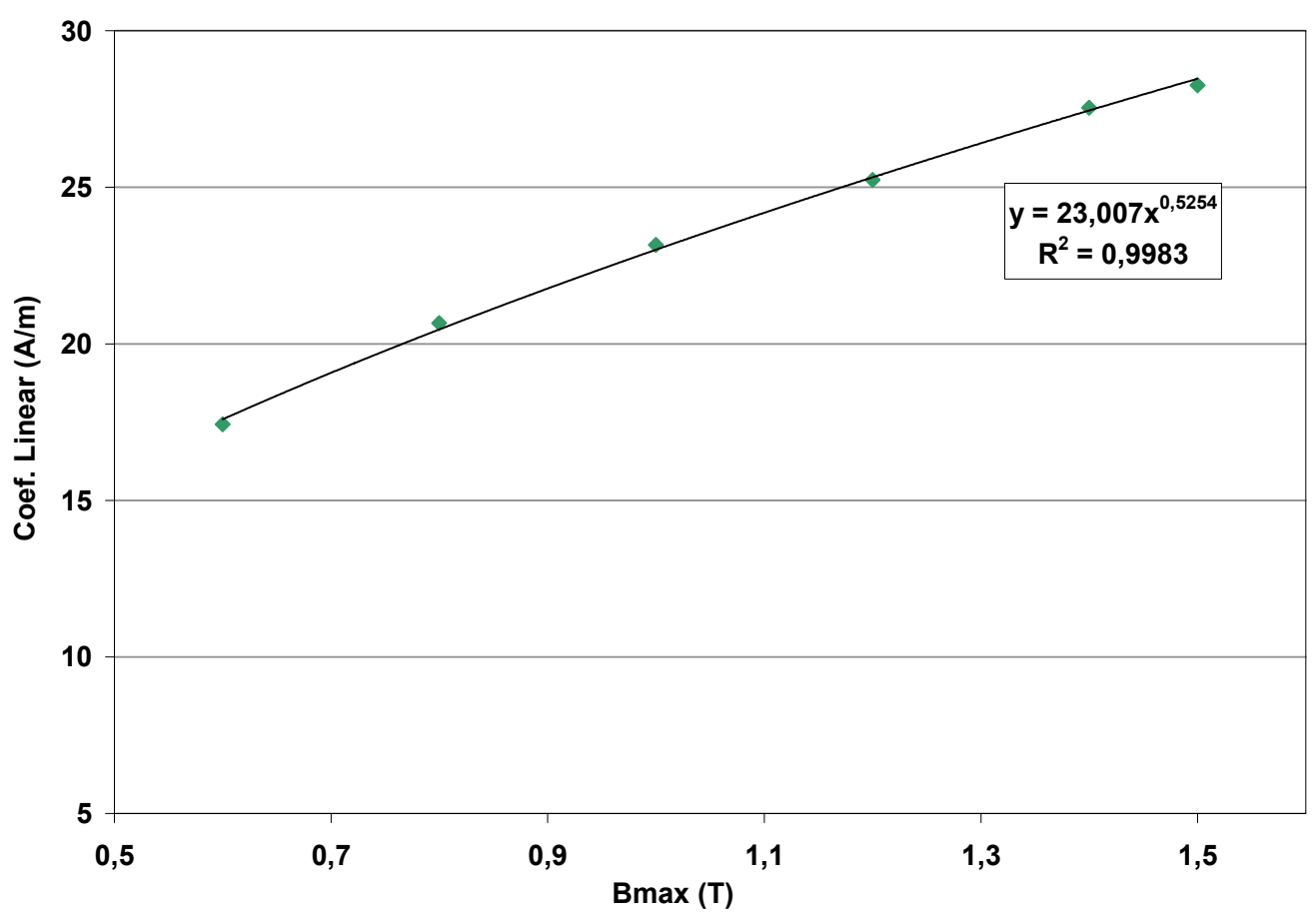

Figura 63: Gráfico do coeficiente linear da reta Hc x 1/l em função da indução máxima. 


\subsection{O efeito do tamanho de grão sobre a energia dissipada por histerese}

A Figura 64 traz o gráfico da energia dissipada na histerese em função do tamanho de grão.

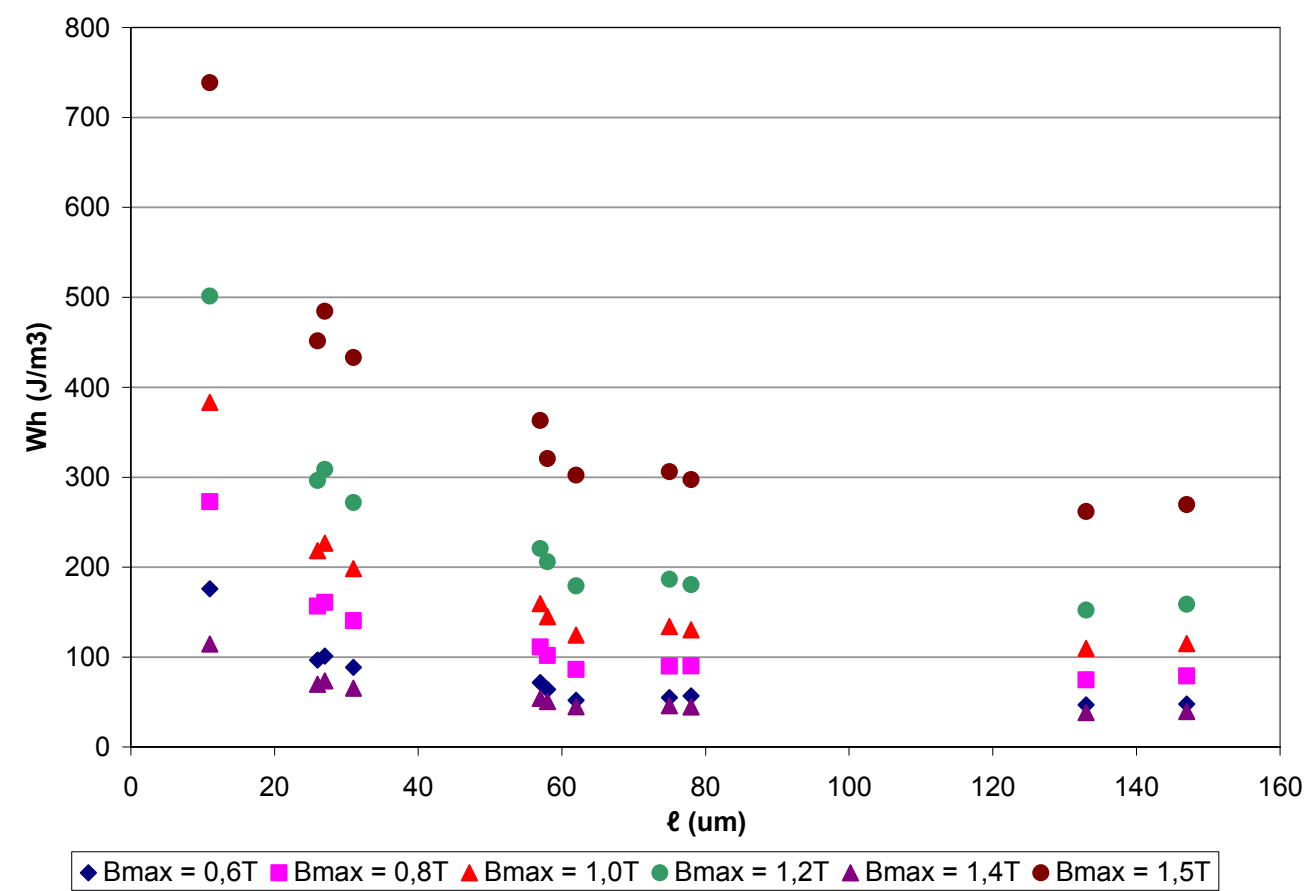

Figura 64: Gráfico da energia dissipada na histerese em função do tamanho de grão.

Sobre a influência do tamanho de grão nas perdas histeréticas também se observou que essa parcela da perda tem seu comportamento melhor descrito como apresentando crescimento linear com o inverso do tamanho de grão como mostra Figura 65. 


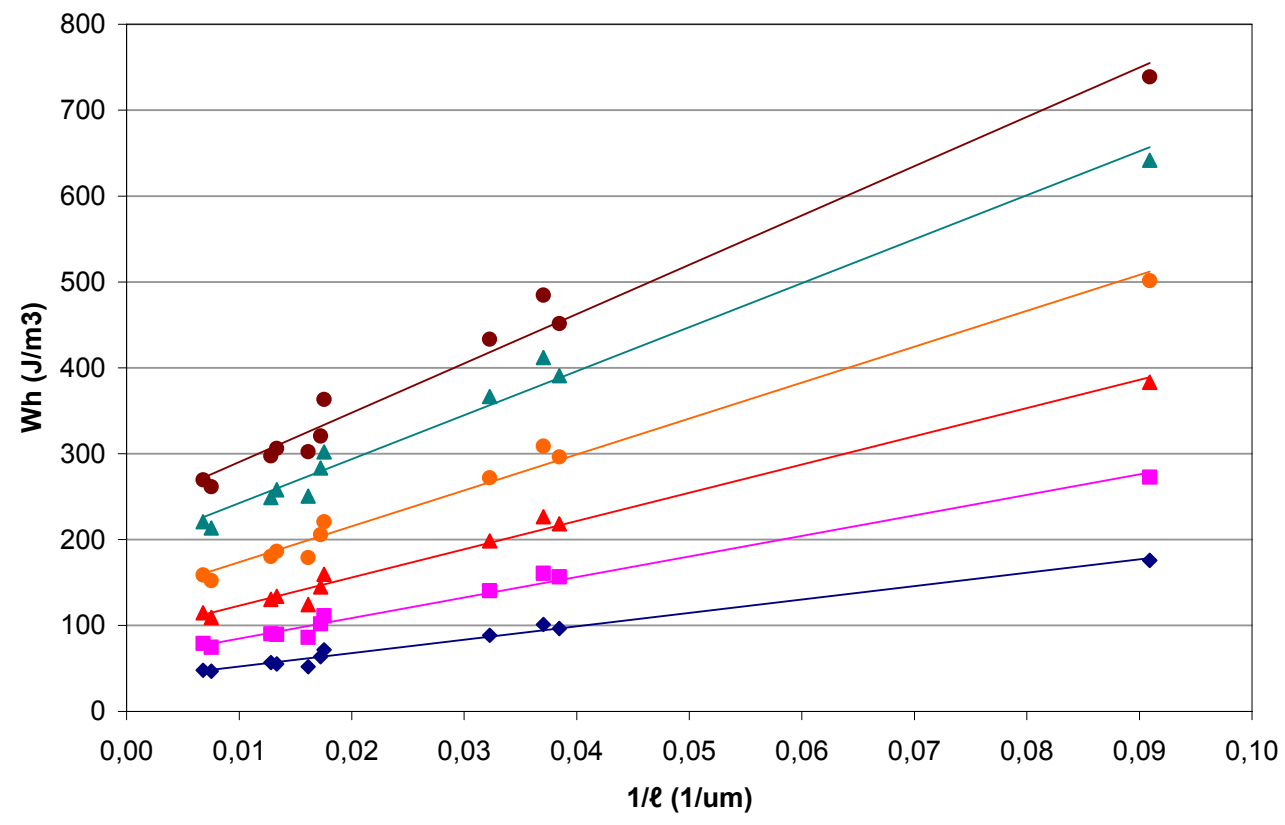

$\bullet \mathrm{Bmax}=0,6 \mathrm{~T} \square \mathrm{Bmax}=0,8 \mathrm{~T} \triangle \mathrm{Bmax}=1,0 \mathrm{~T} \bullet \mathrm{Bmax}=1,2 \mathrm{~T} \triangle \mathrm{Bmax}=1,4 \mathrm{~T} \bullet \mathrm{Bmax}=1,5 \mathrm{~T}$

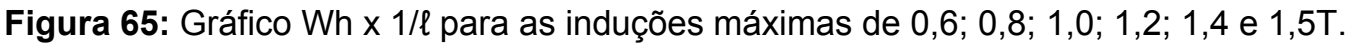

Para a faixa de induções analisadas a lei de dependência $W h \propto 1 / \sqrt{ } \ell$ apresentou menor $\mathrm{R}^{2}$ para um ajuste linear. Conforme indica Tabela 12.

Tabela 12: Coeficientes lineares e angulares e índices de determinação para as retas $W h \propto 1 / \ell$ e Wh $\propto 1 / \sqrt{ } \ell$ em diversos valores de indução máxima.

\begin{tabular}{|c|c|c|c|c|c|c|}
\cline { 2 - 7 } \multicolumn{1}{c|}{} & \multicolumn{3}{c|}{ Wh = a + b/l } & \multicolumn{3}{c|}{ Wh = c + d/ $/ \mathbf{l}$} \\
\hline $\mathbf{B}(\mathbf{T})$ & $\mathbf{a}$ & $\mathbf{b}$ & $\mathbf{R}^{\mathbf{2}}$ & $\mathbf{c}$ & $\mathbf{d}$ & $\mathbf{R}^{\mathbf{2}}$ \\
\hline $\mathbf{0 , 6}$ & 36,72 & 1558,2 & 0,985 & $-10,78$ & 587,64 & 0,964 \\
\hline $\mathbf{0 , 8}$ & 60,92 & 2389,1 & 0,986 & $-12,27$ & 903,37 & 0,970 \\
\hline $\mathbf{1 , 0}$ & 90,00 & 3288,3 & 0,988 & $-10,27$ & $1.240,31$ & 0,967 \\
\hline $\mathbf{1 , 2}$ & 131,70 & 4182,7 & 0,986 & 2,874 & $1.586,09$ & 0,976 \\
\hline $\mathbf{1 , 4}$ & 191,16 & 5122,5 & 0,983 & 32,49 & $1.948,46$ & 0,979 \\
\hline $\mathbf{1 , 5}$ & 233,00 & 5741,4 & 0,980 & 55,62 & $2.180,78$ & 0,973 \\
\hline
\end{tabular}

Também o coeficiente angular das retas Wh $\times 1 / \ell$ é dependente da indução máxima, porém, nesse caso o aumento do coeficiente angular com a indução segue uma lei de potência conforme descrito na Figura 66. 


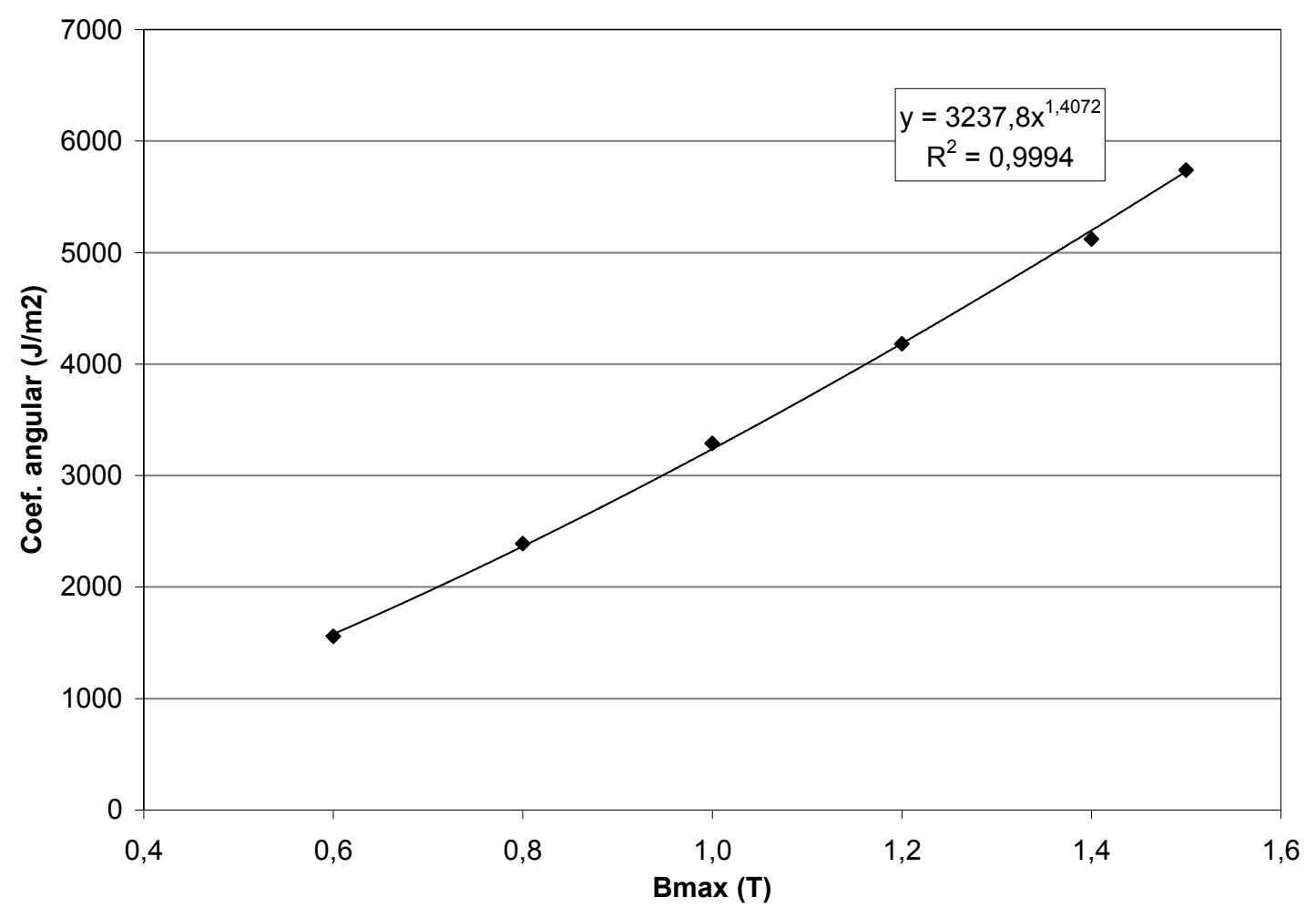

Figura 66: Gráfico do coeficiente angular da curva $\mathrm{Ph} X 1 / \ell$ em função da indução máxima.

O coeficiente angular, o coeficiente linear da reta Wh $\times 1 / \ell$ também é dependente da indução máxima conforme pode ser visto no gráfico da Figura 67.

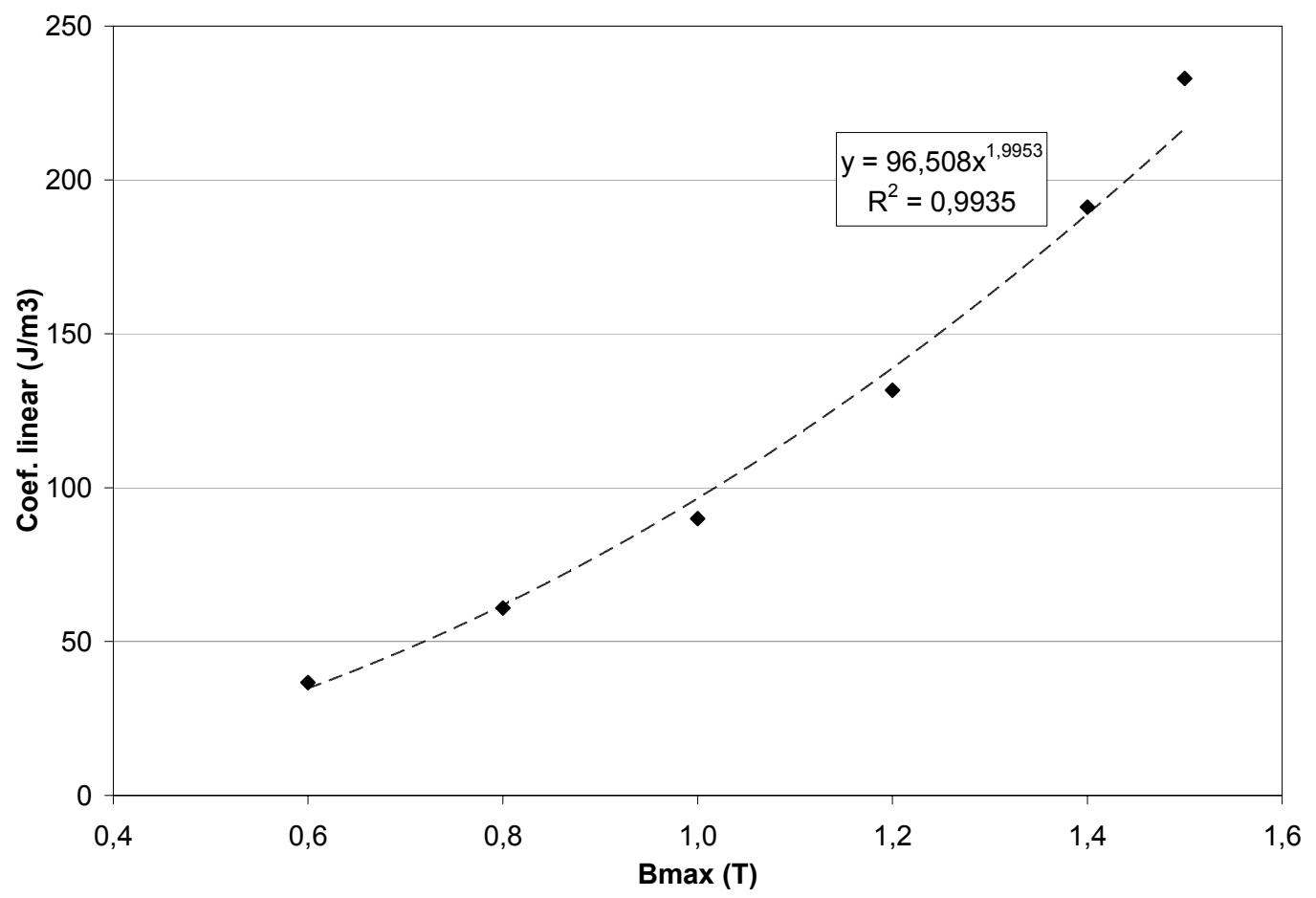

Figura 67: Gráfico do coeficiente linear da reta $\mathrm{Ph}$ x 1/l em função da indução máxima. 
Analisando-se os gráficos que trazem os coeficientes linear e angular em função da máxima indução e somando-se esses dados á reta Wh x 1/l é possível construir uma equação que relacione a energia dissipada por histerese ao tamanho de grão e à indução máxima. Os resultados obtidos aqui levam à Equação 18.

$$
W_{h}=96,058 \times B^{1,9953}+\frac{3237,8 \times B^{1,4073}}{l} \text { Equação } 18
$$

Os resultados experimentais bem como a energia dissipada calculada através da Equação 18 estão contidos na Figura 68.

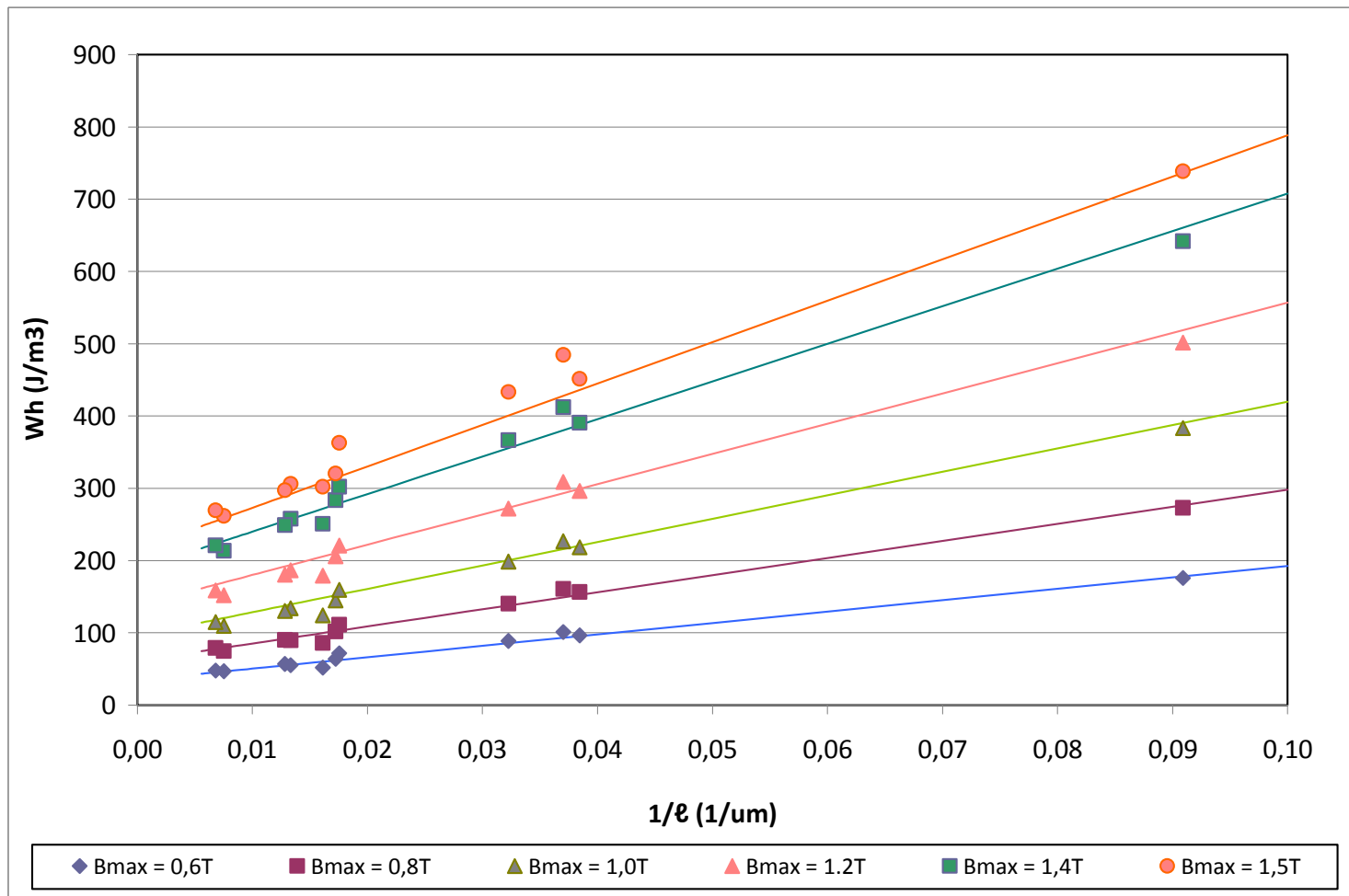

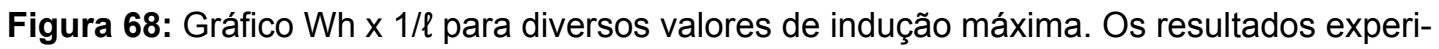
mentais são indicados por pontos e as retas foram calculadas através da Equação 18.

Analisando-se as perdas histeréticas observa-se que elas aumentam de maneira linear com o inverso do tamanho de grão. A Figura 69 traz uma com- 
paração entre as retas de ajustes obtidas nesse trabalho e retas construídas a partir dos resultados de Bertotti.

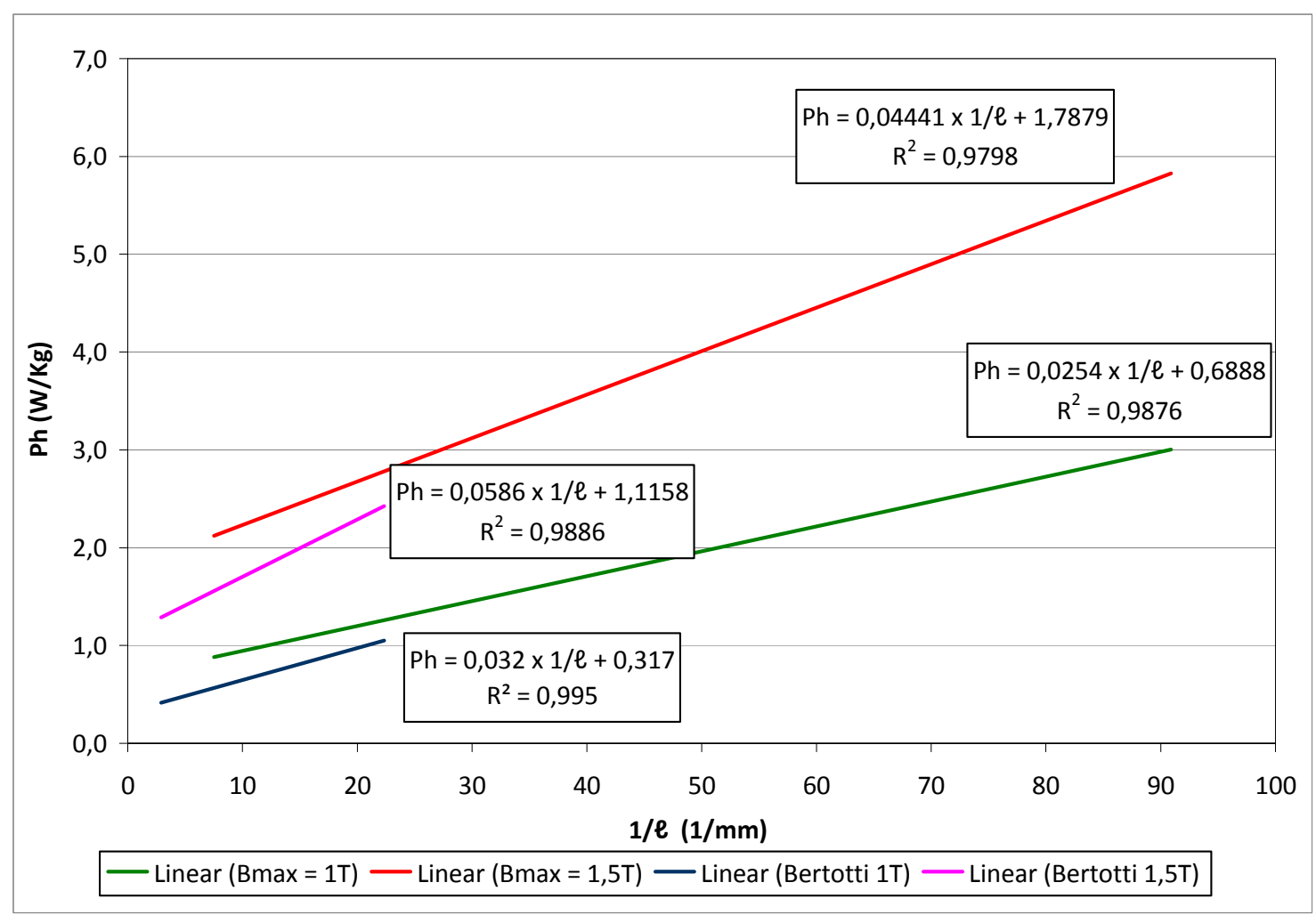

Figura 69: Gráfico $\mathrm{Ph} \times 1 / \ell$ comparando retas produzidas nesse trabalho e as produzidas a partir dos resultados de Bertotti.

\subsection{A relação entre tamanho de grão e perdas totais}

A relação entre perdas totais a 1,0 e 1,5T e tamanho de grão é descrita na Figura 70. 


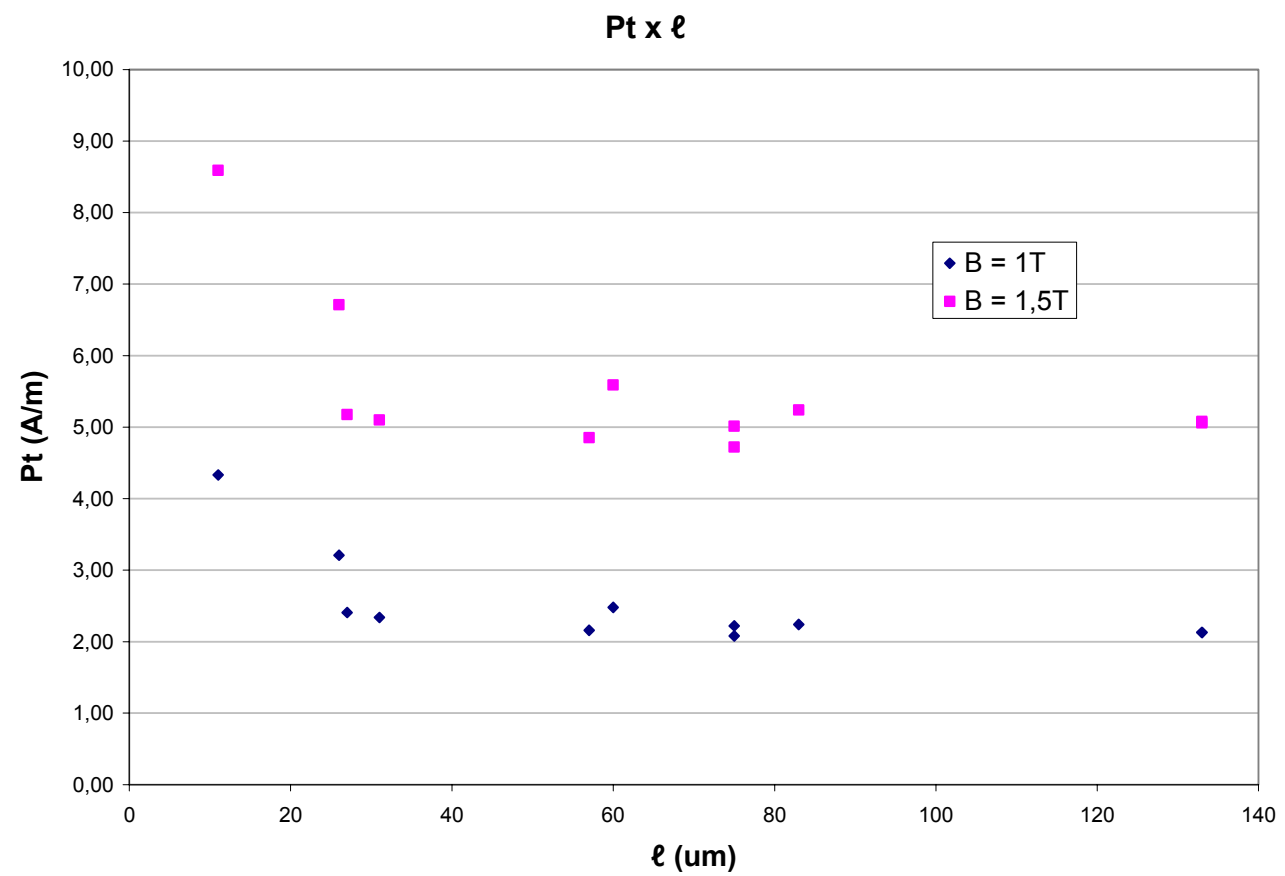

Figura 70: Gráfico das perdas totais em função do tamanho de grão $(\ell)$.

Poucas informações adicionais podem ser extraídas da Figura 70 em função de o escopo de tamanho grão obtido ser muito restrito. A pequena faixa de tamanhos de grão observadas neste trabalho (de 11 a $137 \mu \mathrm{m}$ ) não permite comparação entre este resultado e a literatura que como citada anteriormente prevê ponto de menor perda para tamanhos de grão entre 100 e 150 $\mu \mathrm{m}$ [54].

Outro fator complicador na análise da Figura 70 está relacionado às diferentes espessuras das amostras. Sendo perda parasita fortemente influenciada pela espessura da amostra (conforme descreve a Equação 7) é de se notar que a espessura também afetará a perda total. Esse fato se revela na comparação entre os pontos referentes às amostras Embraco $600^{\circ} \mathrm{C} 2 \mathrm{~h}$ e SEW 343. As duas têm tamanho de grão muito próximo, 26 e $27 \mu \mathrm{m}$, respectivamente. No entanto, as perdas totais são bastante diferentes, sendo bem menores para SEW 343 para as induções máximas de 1,0 e 1,5T. Isso se deve á menor espessura de SEW 343 que a torna a amostra de menor perda parasita de acordo com o gráfico da Figura 71. 


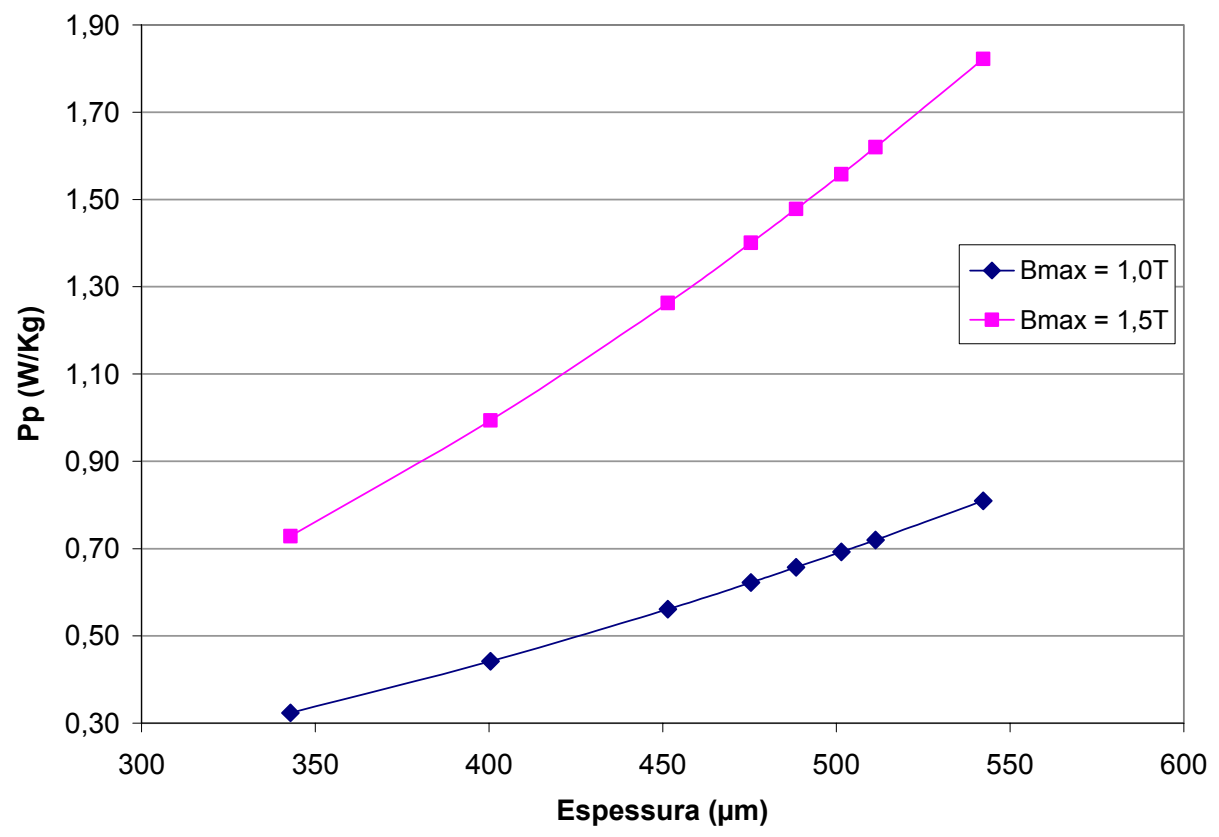

Figura 71: Gráfico das perdas parasitas (Pp) em função da espessura das amostras.

A separação das perdas ilustradas pelos gráficos da Figura 72 e da Figura 73, permitem maior avaliação das perdas em suas várias parcelas.

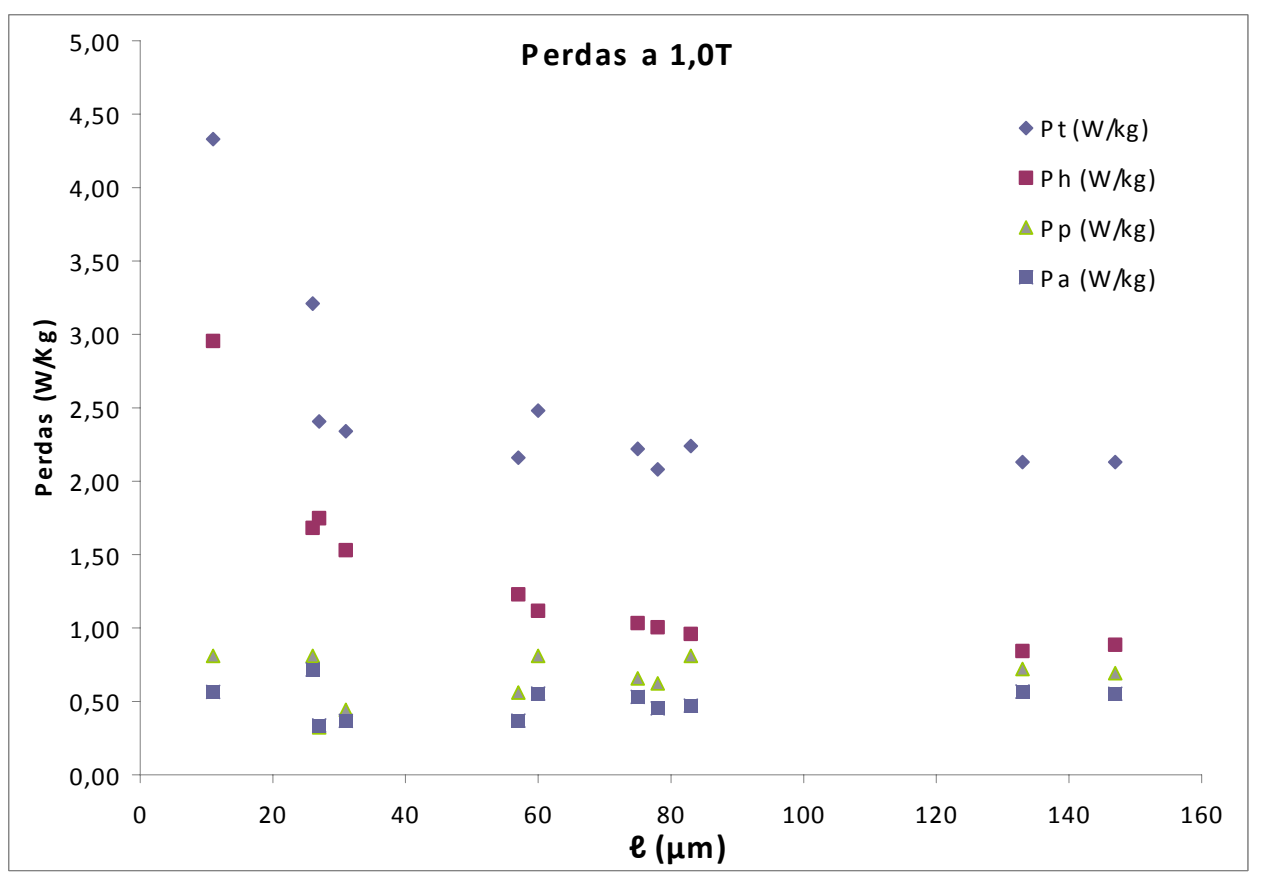

Figura 72: Gráfico relacionando as perdas total $(\mathrm{Pt})$, histerética $(\mathrm{Ph})$, parasita $(\mathrm{Pp})$ e anômala $(\mathrm{Pa})$ ao tamanho de grão $\ell$ para indução máxima de 1,0T. 


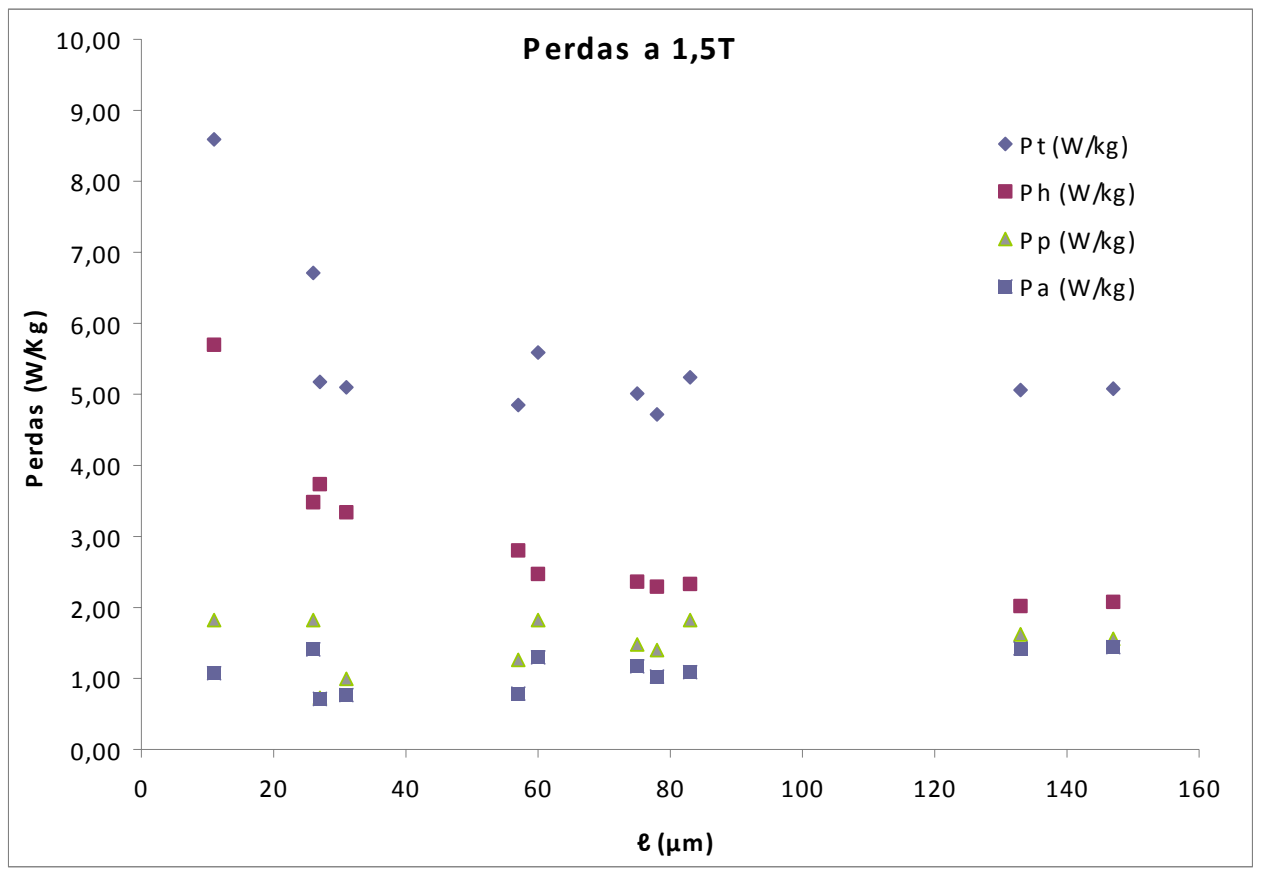

Figura 73: Gráfico relacionando as perdas total $(\mathrm{Pt})$, histerética $(\mathrm{Ph})$, parasita $(\mathrm{Pp})$ e anômala $(\mathrm{Pa})$ ao tamanho de grão $\ell$ para indução máxima de 1,5T.

Nas duas induções (1,0 e 1,5T) as perdas anômalas acompanham as perdas parasitas sugerindo um indício de que elas não sejam afetadas apenas pelo tamanho de grão, há também alguma influência da espessura. Ainda assim uma análise das perdas anômalas é complicada pois os mecanismos que governam essa parcela da perda total ainda não estão esclarecidos.

\subsection{O efeito da indução máxima sobre a energia dissipada por histerese}

A Figura 74 mostra o efeito da indução máxima sobre a energia dissipada na histerese. Nela a curva Wh x B é plotada para cada uma das amostras com indução máxima variando entre 0,6 e 1,5T. Vale ressaltar que Wh é a energia dissipada por ciclo dada pela área do ciclo de histerese na unidade $\mathrm{J} / \mathrm{m}^{3}$.

Para esse intervalo de induções as equações das linhas de tendência fogem do proposto por Steinmentz. Essas linhas se ajustam a uma lei de potência, porém, os valores de coeficiente exponencial (q), listados na Tabela 13, estão sempre superiores a 1,6 chegando a atingir 1,895 para a amostra de tamanho de grão $\ell=62 \mu \mathrm{m}$. 


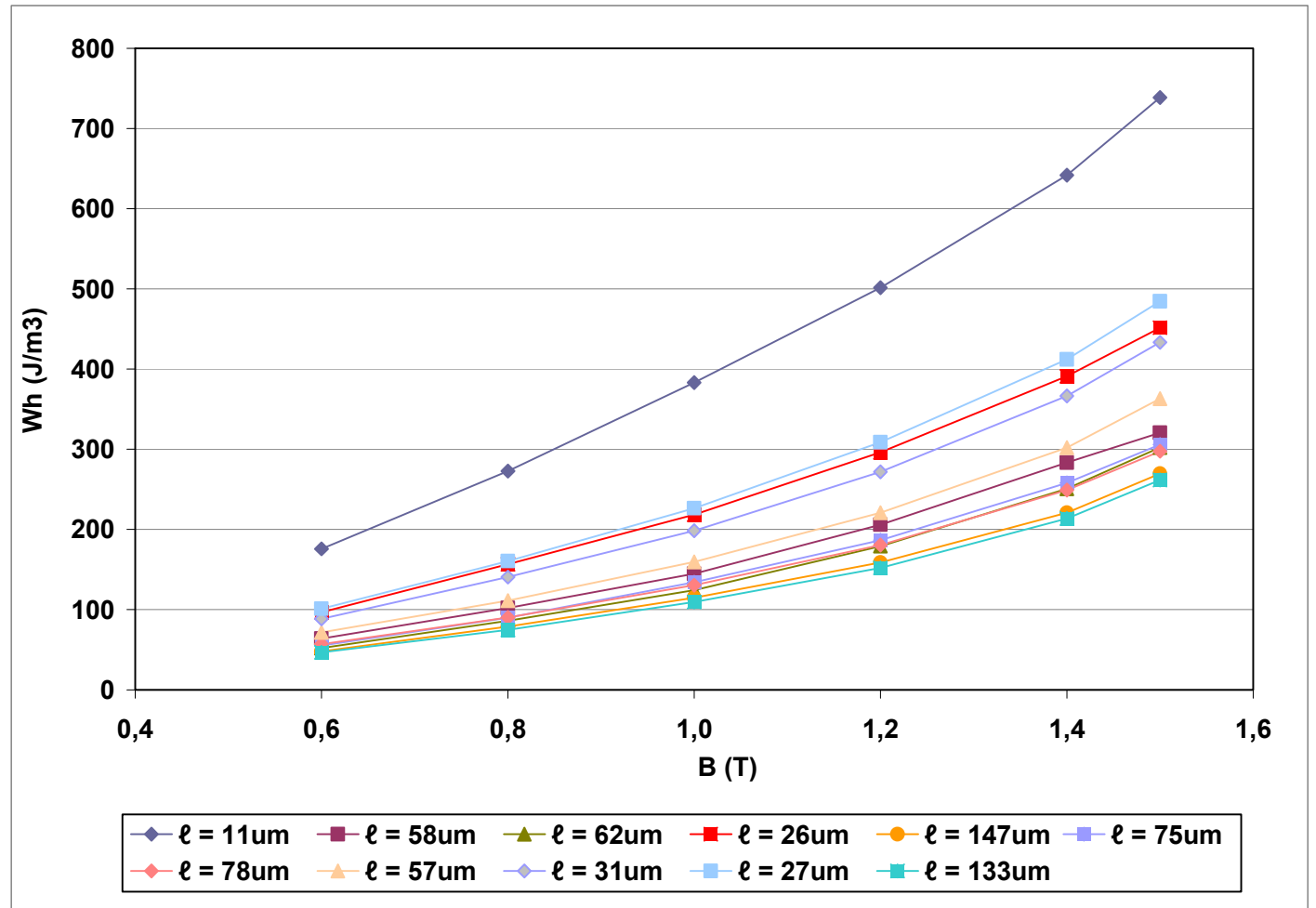

Figura 74: Gráfico da perda histerética (Wh) em função da indução máxima (B) para amostras com diferentes tamanhos de grão para valores de B entre 0,6 e 1,5T.

Tabela 13: Valores do número pré-exponencial (k),do coeficiente exponencial (q) e do índice de determinação $R^{2}$ para as equações de ajustes que descrevem o efeito da indução máxima sobre a emergia dissipada por histerese para cada uma das amostras.

\begin{tabular}{|l|c|c|c|}
\cline { 2 - 4 } \multicolumn{1}{c|}{} & $\mathbf{k}$ & $\mathbf{q}$ & $\mathbf{R}^{\mathbf{2}}$ \\
\hline Embraco - 600C 2h & 384,9 & 1,547 & 0,999 \\
\hline Embraco - 850C 4h & 152,5 & 1,769 & 0,997 \\
\hline Embraco - 850C 8h & 131,9 & 1,895 & 0,995 \\
\hline SEW 542 & 223,7 & 1,661 & 0,998 \\
\hline SEW 511 & 114,7 & 1,849 & 0,993 \\
\hline SEW 501 & 119,3 & 1,848 & 0,995 \\
\hline SEW 488 & 137,8 & 1,855 & 0,997 \\
\hline SEW 475 & 136,0 & 1,785 & 0,995 \\
\hline SEW 451 & 167,4 & 1,750 & 0,994 \\
\hline SEW 400 & 206,2 & 1,709 & 0,996 \\
\hline SEW 343 & 234,0 & 1,686 & 0,997 \\
\hline
\end{tabular}

Para o intervalo de induções compreendido entre 0,6 e 1,2T (gráfico da Figura 75) há uma melhora na qualidade do ajuste e ligeira queda no valor de $\mathrm{k}$ porém os valores dos coeficientes exponenciais continuam a fugir do previsto pela lei da histerese de Steinmetz conforme mostram os dados listados na Tabela 14. 


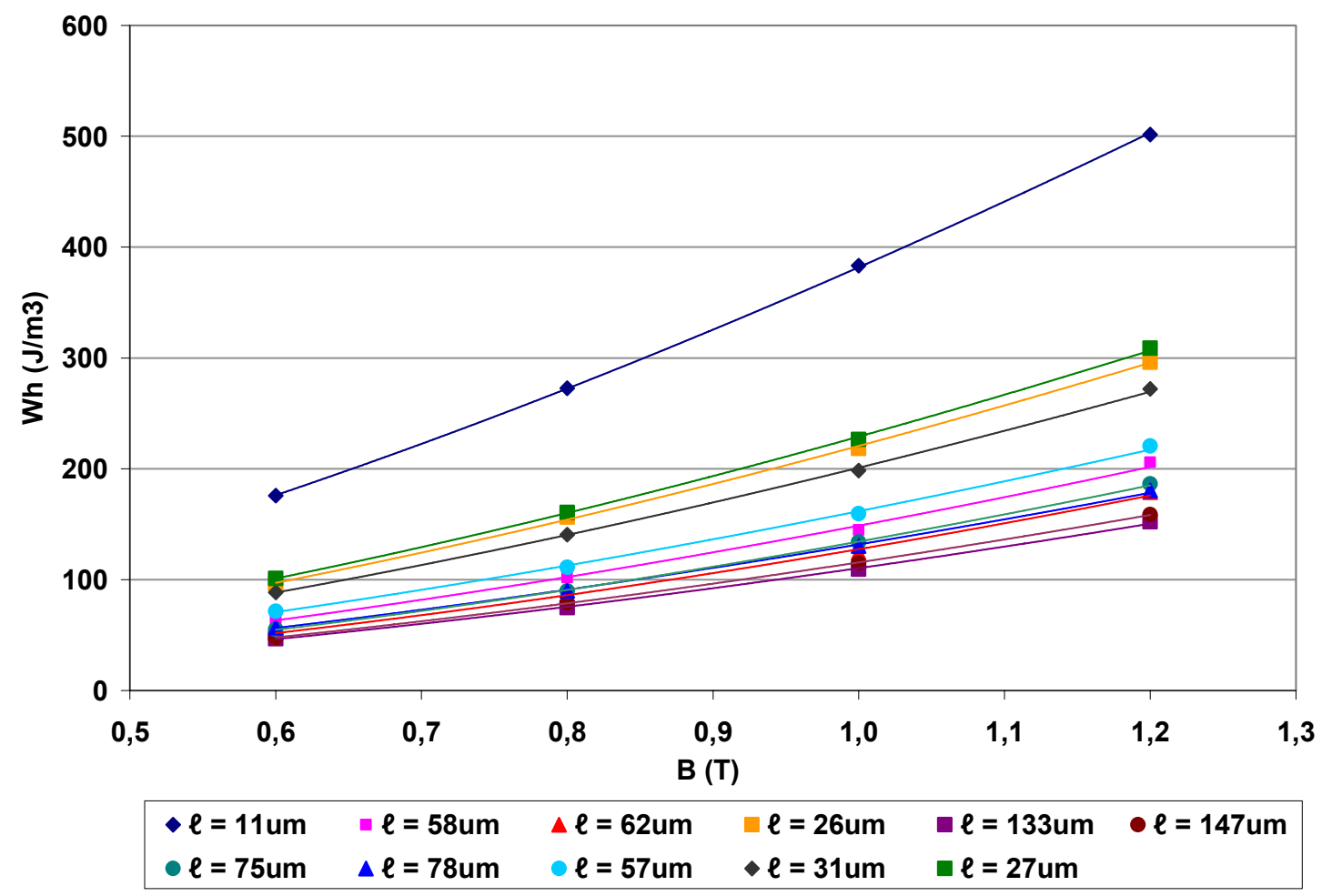

Figura 75: Gráfico Ph x B para o intervalo de induções entre 0,6 e 1,2T.

Tabela 14: Valores do coeficiente pré-exponencial (k), coeficiente exponencial (q) e índice de determinação $\left(R^{2}\right)$ para as equações de ajuste que descrevem a curva Wh $\times$ Bmax com indução máxima variando entre 0,6 e 1,2T para cada uma das amostras.

\begin{tabular}{|l|c|c|c|}
\cline { 2 - 4 } \multicolumn{1}{c|}{} & $\mathbf{k}$ & $\mathbf{q}$ & $\mathbf{R}^{\mathbf{2}}$ \\
\hline Embraco - 600C 2h & 381,8 & 1,514 & 1,0000 \\
\hline Embraco - 850C 4h & 148,7 & 1,674 & 0,9984 \\
\hline Embraco - 850C 8h & 127,5 & 1,765 & 0,9988 \\
\hline SEW 542 & 220,6 & 1,607 & 0,9994 \\
\hline SEW 511 & 110,4 & 1,701 & 0,9995 \\
\hline SEW 501 & 115,6 & 1,726 & 0,9999 \\
\hline SEW 488 & 134,4 & 1,758 & 0,9997 \\
\hline SEW 475 & 131,8 & 1,663 & 0,9995 \\
\hline SEW 451 & 161,8 & 1,619 & 0,9989 \\
\hline SEW 400 & 201,0 & 1,610 & 0,9996 \\
\hline SEW 343 & 229,0 & 1,603 & 0,9998 \\
\hline
\end{tabular}

O gráfico da Figura 76 relaciona o coeficiente pré-exponencial ao tamanho de grão da estabelecendo uma relação entre o tamanho de grão e a lei de Steinmetz. Este gráfico descreve o crescimento linear do coeficiente pré- 
exponencial da equação empírica de Steinmetz $(\mathrm{k})$ com o inverso do tamanho de grão (l).

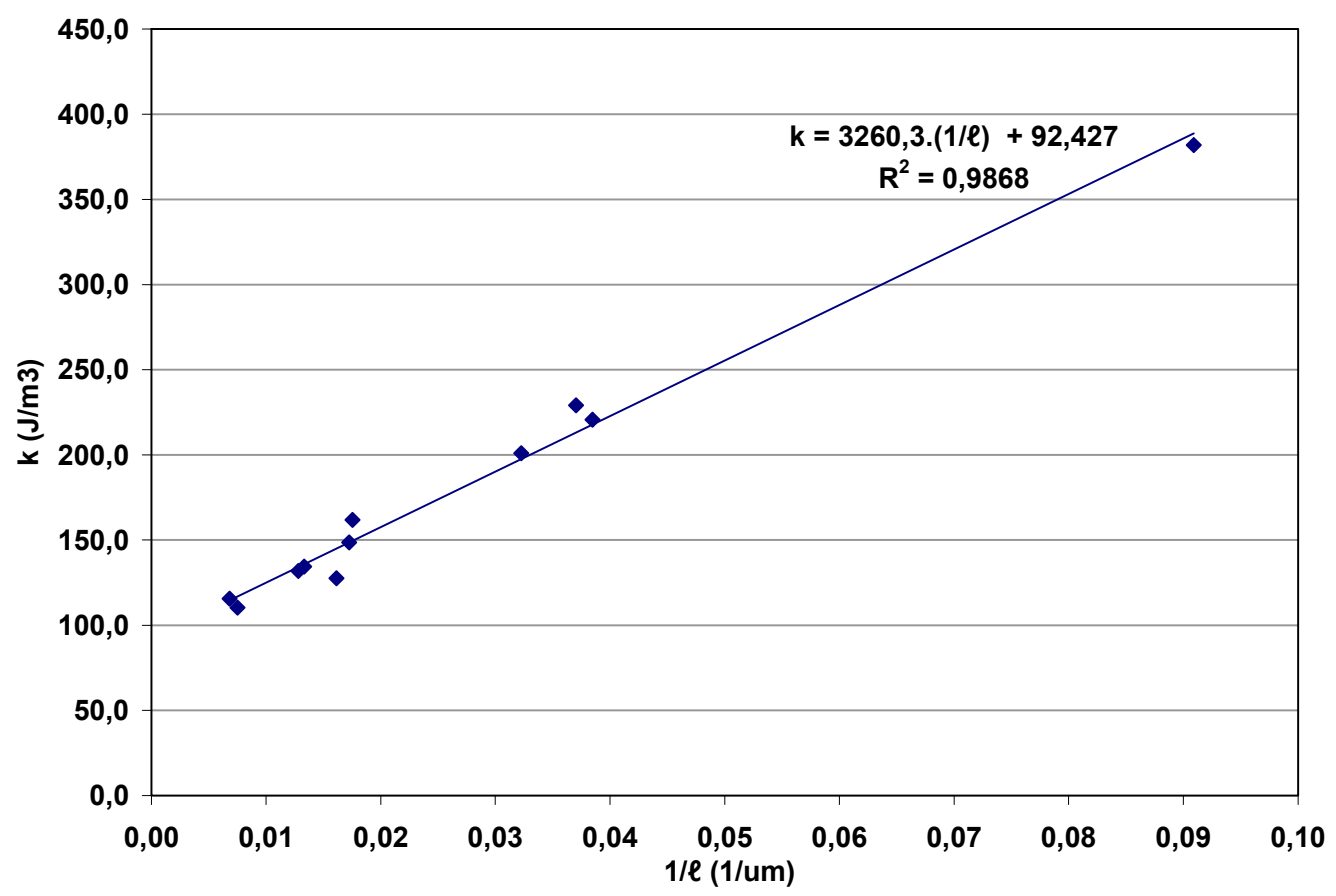

Figura 76: Gráfico k x 1/l para indução variando ente 0,6 e 1,2T.

Autores discutem como características microestruturais afetam o coeficiente de Steinmetz, sobretudo o comportamento dessa constante com relação ao ângulo formado entre a direção de aplicação do campo magnético e a direção de laminação da chapa [60]. Quanto a o coeficiente numérico, Ball [58] apenas afirma que este tem valor dependente do material. O gráfico da Figura 76 aprofunda essa afirmação mostrando que o valor do coeficiente numérico é dependente da estrutura de grãos desse material.

Sobre a influência do tamanho de grão sobre o coeficiente de Steinmetz o gráfico da Figura 77 relata uma curva de potência, porém os dados experimentais não se ajustam bem à linha de tendência reduzindo a confiabilidade do ajuste. 


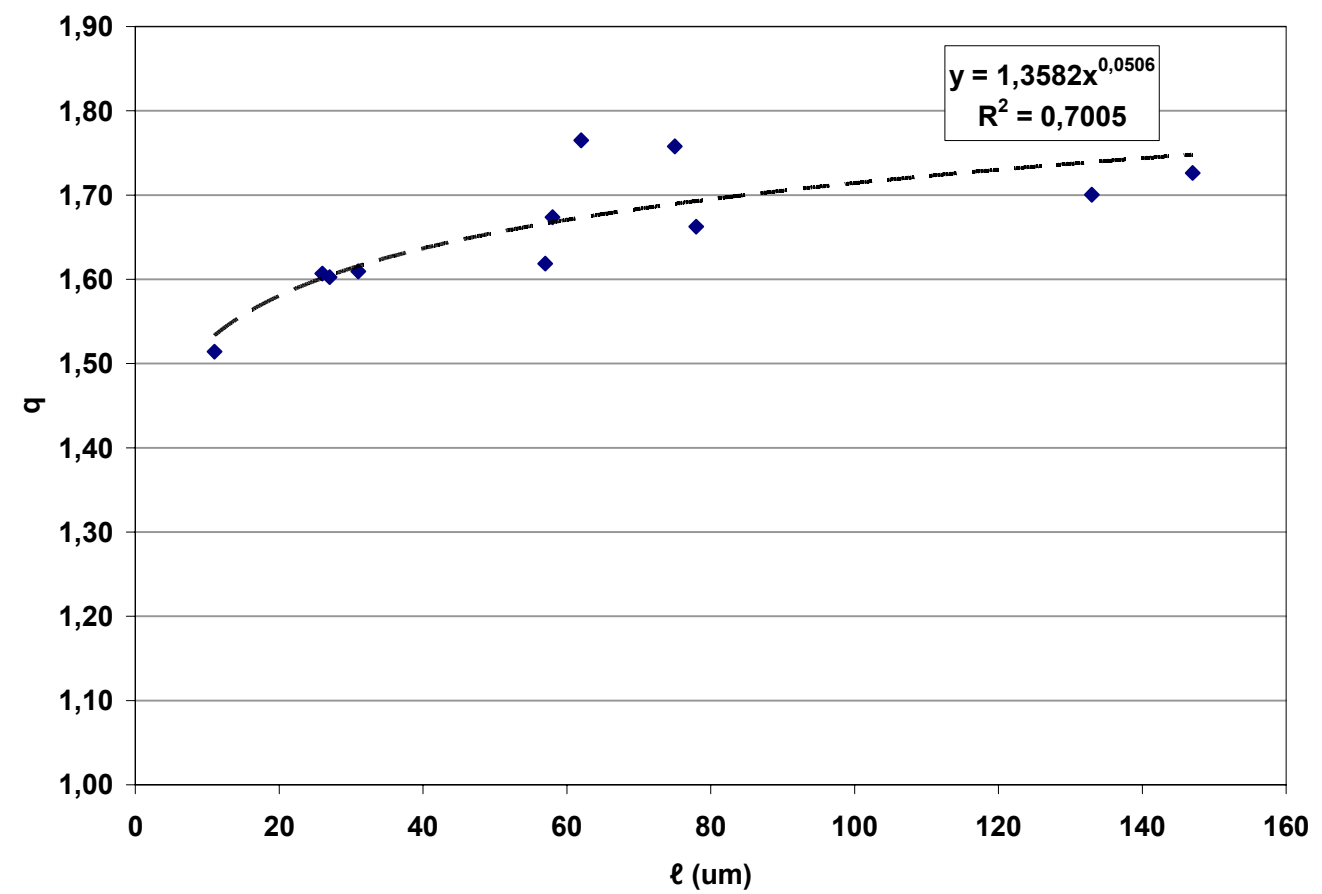

Figura 77: Coeficiente de Steinmetz (q) em função do tamanho de grão $(\ell)$ para faixa de induções entre 0,6 e $1,2 \mathrm{~T}$. 


\section{CONCLUSÕES}

Neste trabalho foram comparados dois métodos de medição de tamanho de grão. Um utilizando a área de grão obtida por análise semi-automática de micrografias, outro utilizando a contagem de interceptos. A comparação entre os resultados desses dois procedimentos mostrou que há uma relação de proporcionalidade entre os valores obtidos, sendo a razão entre os valores medidos pelo método dos interceptos e os medidos pelo método das áreas aproximadamente constante $(=0,63)$ no domínio considerado.

A respeito do comportamento do campo coercivo com o aumento do tamanho de grão, conclui-se que para a os valores de indução máxima analisada ele é melhor descrito como o valor do campo coercivo tendo crescimento linear com o inverso do tamanho de grão ( $\mathrm{Hc} \propto 1 / \ell)$. Essa afirmação está baseada no fato de as retas de ajustes para essa lei de dependência apresentarem $R^{2}$ mais próximo de 1 que as retas para $\mathrm{Hc} \propto 1 / \sqrt{ } \ell$.

Pelo fato de os resultados obtidos pelos dois métodos de medição de tamanho de grão apresentarem uma razão constante $(0,63)$ pode-se concluir que a escolha do método não afeta o comportamento do campo coercivo com a evolução do tamanho de grão.

$\mathrm{O}$ coeficiente angular das retas dadas por $\mathrm{Hc}=\mathrm{a}+\mathrm{b} / \ell$ é fortemente dependente do valor da indução máxima. A relação entre o coeficiente angular e a indução máxima pode ser descrita por uma função logarítmica. Também o coeficiente linear é dependente da indução máxima seguindo uma função logarítmica.

O trabalho é inconclusivo na avaliação do efeito do tamanho de grão sobre a perda total uma vez que a faixa de tamanho de grão obtida para esse experimento foi muito restrita, com TG máximo de $147 \mu \mathrm{m}$ impossibilitando a comparação com o comportamento previsto pela literatura que prevê ponto mínimo para a perda total em tamanho de grão próximo a 150 $15 \mathrm{~m}$.

Sobre o efeito da indução na perda histerética os resultados mostram que para o intervalo de indução entre 0,6 e 1,2T a lei da histerese proposta por Steinmetz é valida mesmo havendo desvios entre os valores dos expoentes das induções máximas obtidos nesse trabalho e o determinado por Steinmetz 
$(=1,6)$. Quanto ao coeficiente pré-exponencial, este é influenciado pela estrutura de grãos do material sendo inversamente proporcional ao tamanho de grão. Como sugestões de continuidade ficam propostos:

* Levantamento dos gráficos $\mathrm{Hc} \times 1 / \ell$ e $\mathrm{Hc} \times 1 / \sqrt{ } \ell$ para avaliar qual dessas duas leis de dependência melhor se ajusta aos pontos experimentais obtidos em altas induções (Bmax > 1,5T).

* Averiguar o campo coercivo de aços de maior tamanho de grão ( $\ell>150 \mu m$ ) para definir se há mudança de comportamento ou dependência de $\mathrm{Hc}$ com o inverso da raiz de TG.

* Verificar o comportamento da perda total para maiores tamanhos de grão ( $\ell>150 \mu \mathrm{m})$ tornando viável a comparação mais adequada com a descrição do comportamento da perda total com o aumento do TG fornecido pela literatura. 


\section{REFERÊNCIAS}

[1] CHIAVERINI, Vicente: "Aços e ferros fundidos: características gerais, tratamentos térmicos e principais tipos", ABM - Associação brasileira de metalurgia e materiais, $7^{a}$ edição, São Paulo - 2005.

[2] MOSES, A. J.: "Electrical steels: past, present and future developments"; IEE Proceedings, Vol. 137, Pt. A, N 5, Setembro de 1990.

[3] GUENTHER, K.: "Challenges in optimizing electrical steels" texto que integra 0 artigo "Challenges in optimizing the magnetic properties of bulk soft magnetic materials"; Journal of Magnetism and Magnetic Materials, $N^{\circ} 320,2008$.

[4] CASTRO, Nicolau Apoema: "Controle da textura e da microtestura durante o processo de fabricação de aços elétricos semiprocessados". Tese de doutorado apresentada à Escola Politécnica da Universidade São Paulo.

[5] COOMBS, A.: "A review of electrical steels". Steel Times, maio 1970.

[6] GOSS, N.: Industrial Heating, vol. 32, $\mathrm{n}^{\circ}$ 6-11.

[7] JILES, David: "Introduction to Magnetism and Magnetic Materials", editora Chapman \& Hall, Londres, primeira edição, 1991.

[8] Site; http://www.mspc.eng.br/elemag/eletrm0260.shtml, data de acesso: 04/06/2009.

[9] Site; http://www.labspot.ufsc.br/ jackie/cap2_new.pdf, data de acesso: 04/06/2009.

[10] CALLISTER, W. D.: "Materials Science and Engineering - An Introduction", Editora John Willey \& Sons, Inc., New York, Sétima edição - 2007.

[11] LANDGRAF, "Propriedades Magnéticas de Aços para fins Elétricos" publicado no site:

http://www.pmt.usp.br/academic/landgraf/nossos $\% 20$ artigos $\% 20 \mathrm{em} \% 20 \mathrm{pdf} / 0$ 2Lan\%20\%20recope\%20.pdf . data de acesso 04/06/2009 
[12] Extraído do site: www.tonmeister.ca/main/textbook/node428.html. Data de acesso 04/06/2009.

[13] Extraído do site: http://wwwseme.dee.fct.unl.pt/ProjectoRuiJardim/Relatorio/Projecto.htm. Data de acesso 04/06/2009.

[14] LANDGRAF, F. J. G.: "Microestrutura e histerese magnética nos aços para fins eletromagnéticos", 2007. Tese (Livre Docência), Escola Politécnica, Universidade de São Paulo, São Paulo, 2007.

[15] HOU, Chun-Kan, "Effect of silicon on the loss separation and permeability of laminated steels". Journal of Magnetism and Magnetic Materials 162, 1996 pags $280-290$.

[16] HOU, Chun-Kan, "The effect of aluminum on the magnetic properties of lamination steel". IEEE Transaction on magnetics, vol 07, n 5 , setembro de 1991.

[17] PADILHA, A. F.; SICILIANO Jr. F.; "Encruamento, Recristalização, Crescimento de Grão e Textura". ABM, São Paulo 1995.

[18] ASHBROOK, R. W. Jr.; MARDER, A. R.: "The effect of initial carbide morphology on abnormal grain growth in decarburized low carbon steel". Metallurgical Transactions, vol. 16A.

[19] LANDGRAF, F. J. G.; TAKANOHASHI, R.; CAMPOS M. F.: "Tamanho de grão e textura dos aços elétricos de grão não-orientado". Capitulo extraído de TSCHIPTSCHINT, A. P. et al.; "Textura e relações de orientação". São Paulo, EPUSP, 2003

[20] ANTONIONE, C. et al.: "Effect of slight deformations on grain growth in iron". Journal of Materials Science, vol. 12, 1977.

[21] RIONTINO, G.; ANTONIONE, C.; BATTEZZATI, L.; MARINO, F.: "Kinetics of abnormal grain growth in pure iron”. Journal of Materials Science 14 (1979).

[22] RIOS, P. R.; SICILIANO Jr., F.; SANDIM, H. R. Z.; PLAUT, R. L.; PADILHA, A. F.: "Nucleation and Growth During Recrystallization". Materials Research, Vol. 8, 2005. 
[23] REED-HILL, R. E.: "Principios de Metalurgia Física". Compañia Editorial Continental, México, 1986.

[24] EASTWOOD, L. W.; BOUSU, A.E.; EDDY, C. T.: Trans. Metall. Soc. A.I.M.E. vol. 41, 1935.

[25] ANTONIONE, C.; DELlAGATTA, G.; RIONTINO, G.; VENTURELLO, G.: "Grain growth and secondary recrystallization in Iron." Journal of Materials Science, vol. 8, 1973.

[26] LIMA, L. M. F. G.; LIMA, N. B.; PADILHA, A. F.: "Evolução da microestrutura e da textura de recristalização, após baixos graus de deformação a frio, em dois aços ferríticos com baixo teor de carbono". Contribuição técnica ao $17^{\circ}$ CBECIMat - Congresso Brasileiro de Engenharia e Ciência dos Materiais, 2006.

[27] LANDGRAF, F. J. G.; HERNALSTEENS, C.: "Crescimento de grão induzido por deformação em aço baixo carbono". Contribuição técnica apresentada no $50^{\circ}$ Congresso anual da ABM. São Paulo 1995.

[28] Extraído do site: http://www.infomet.com.br/glossario.php. Data de acesso: $18 / 11 / 2009$.

[29] HILLERT, M.: "On the theory of normal and abnormal grain growth". Acta Metallurgica, vol. 13, 1966.

[30] BURKE, J. E.: TURNBULL, D.: "Recrystallization and grain growth". Progress in Metal Physics. Pergamon Press, vol. 3. Londres 1952.

[31] CAHN, R. W.: "Recovery and Recrystallization", extraído de "Physical Metallurgy". North-Holland, segunda edição. Londres 1970.

[32] COLE, D. G.; FELTHAM, P.; GILLAM, E.: "On the mechanism of grain growth in metals, with special reference to steel". Proceedings of the Physical Society. Section B. vol. 67. 1954.

[33] SIDOR, Y.; KOVAC, F.: "Microestructural aspects of grain growth kinetics in non-oriented electrical steel”. Materials Characterization, vol. 55 (2005). 
[34] HUMPHREYS, F. J.; HATHERLY, M.: "Recrystallization and Related Annealing Phenomena. Oxford: Pergamon; 1996.

[35] SIDOR, Y.; KOVAC, F.; PETRYCHKA, V.: "Secondary recrystallization in non-oriented electrical steels". Metalurgija, vol. 44, 2005.

[36] ALCÂNTARA, F. L.; CUNHA, M. A.: "Estudo da recristalização secundária do aço silício de grão orientado". Tecnologia em Metalurgia e Materiais. São Paulo, v. $2 n^{\circ} 3,2006$.

[37] MAY, J. E.; TURNBULL, D.: "Secondary recrystallization in silicon iron". Transactions of the Metallurgical Society of AIME. Vol. 212, dezembro, 1958.

[38] EMURA, M. ; CAMPOS, M.F. ; LANDGRAF, F. J. G. ; TEIXEIRA, J. C. . "Angular Dependence of Magnetic Properties of $2 \%$ Silicon electrical Steel". Journal of Magnetism and Magnetic Materials, Holanda, v. 226, p. 15241526, 2001.

[39] LANDGRAF, F. J. G.; EMURA, M.; TEIXEIRA, J.C.; de CAMPOS, M. F.; MURANAKA, C.S.: "Anisotropy of the magnetic losses in semi-processed electrical steels". Journal of Magnetism and Magnetic Materials, 196-197 (1199) 380-38t.

[40] PARK, J. T.; SZPUNAR, J. A.: "Effect of initial grain size on texture evolution and magnetic properties in noriented electrical steels". Journal of Magnetism and Magnetic Materials 321 (2009) 1928-1932.

[41] YENSEN, T. D., "Magnetically soft materials", Transactions of the A.S.M. Sep. 1939.

[42] ASTM Standard, E 1121996 (2004), "Standard test methods for determining average grain size", ASTM International, West Conshohocken.

[43] DEGAUQUE, J. et al., "Influence of the grain size on the magnetic and magnetomechanical properties of high-purity iron", Journal of Magnetism and Magnetic Materials v. 26, 1982. 
[44] BATTISTINI, L., BENASCIUTTI, R., TASSI, A., "Effect of heat treatment on crystallographic and magnetic properties of magnetic steels", Journal of Magnetism and Magnetic Materials, 1994.

[45] ADLER, E., PFEIFFER, H., "The influence of grain size and impurities on the magnetic properties of the soft magnetic alloy $47,5 \%$ NiFe", p.172, IEEE Transactions on Magnetics, vol.mag-10. Junho, 1974.

[46] BERTOTTI, G., DI SCHINO, G., MILONE, A. F., FIORILLO, F., "On the effect of grain size on magnetic losses of $3 \%$ non-oriented SiFe", Journal de Physique, setembro, 1985.

[47] MAGER, A., Correspondência pessoal enviada a LANDGRAF, F. J. G., anexo em [14].

[48] DÖRING, W., "Über das Anwachsen der Ummagnetisierungskeime bei großen Barkhausen-Sprüngen”, Zeitschrift für Physic, v.108, p. 137-152, 1938.

[49] Da SILVEIRA, J. R. F.: "Efeito do tamanho de grão obtido por laminação e recozimento sobre as perdas histeréticas em aços para fins elétricos". TrabaIho de graduação apresentado à Escola Politécnica da Universidade de São Paulo para a obtenção do título de Bacharel em Engenharia de Materiai, 2009.

[50] BAN, G.; BERTOTTI, G.: "Dependence on peak induction and grain size of power losses in nonoriented SiFe steels". Journal of Applied Physics. Vol. 64, novembro, 1988.

[51] CAMPOS, M. F.; YONAMINE, T.; FUKUHARA, M.; LANDGRAF, F. J. G.; ACHETE, C. A.; MISSEL, F. P.: "Effects of frequency on the iron losses of $0,5 \%$ and $1,5 \%$ Si nonoriented electrical steels". IEEE Transactions on Magnetics, vol. 42, n 10, outubro, 2006.

[52] SHIMANAKA, H.; ITO, Y.; MATSUMURA, K.; FUKUDA, B.: "Recent development of non-oriented electrical steels". Journal of magnetism and Magnetic Materials, vol. 26, 1982. 
[53] SHIOZAKI, M.; KUROSAKI, Y.: "The effect of grain size on the magnetic properties of nonoriented electrical steel sheets". Journal of Materials Engineering, 1989,

[54] CUNHA, M. A.; PAOLINELLI, S. C.; CÉSAR, M. G. M. M.: "Avanços na produção de aço silício de grão não-orientado na Acesita". Contribuição técnica ao $56^{\circ}$ Congresso Anual da ABM.

[55] TAKASHIMA, M.; MORITO, N.; HONDA, A.; MAEDA, C.: "Nonoriented electrical steel with low iron loss for high-efficiency motor cores". IEEE Transaction on Magnetics, vol. 35, n 1, Janeiro 1999.

[56] CAMPOS, M. F.; TEIXEIRA, J. C.; LANDGRAF, F. J. G.: "The optimum grain size for minimizing energy losses in iron". Journal of Magnetism and Magnetic Materials, vol. 301, 2006.

[57] STEINMETZ, C. P.: "On the law of Hysteresis". Transactions AIEE, v.9, 1892,

[58] BALL, J. D.: "Investigation of magnetic laws for steel and other material". Journal of the Franklin Institute, Vol. 181, Issue 4, April 1916.

[59] LANDGRAF, F. J. G.; EMURA, M.; CAMPOS, M. F.: "On the Steinmetz hysteresis law". Journal of Magnetism and Magnetic Materials. Vol. 320, 2008

[60] EMURA, M.; LANDGRAF, F. J. G.: "Efeito da indução máxima nas perdas magnéticas de aço $3 \% \mathrm{Si}$ ". Contribuição técnica ao $57^{\circ}$ Congresso Internacioal da ABM, 2002.

[61] ASTM Standard, E 3 - 01 (2007), "Standard test methods for determining average grain size", ASTM International, West Conshohocken.

[62] SHEWMON, P. G.; "Transformation in metals", editora: McGraw-Hill Company; New York, 1969. 


\section{APÊNDICE}

São mostrados aqui, os ciclos de histerese para cada uma das amostras. Esses ciclos foram produzidos em ensaio quase-estático para seis diferentes valores de indução máxima. As amostras estão divididas em dois grupos de acordo com o método usado para proporcionar aumento de tamanho de grão (crescimento de grão e recristalização).

7.1 Histereses das amostras com aumento do tamanho de grão por crescimento.

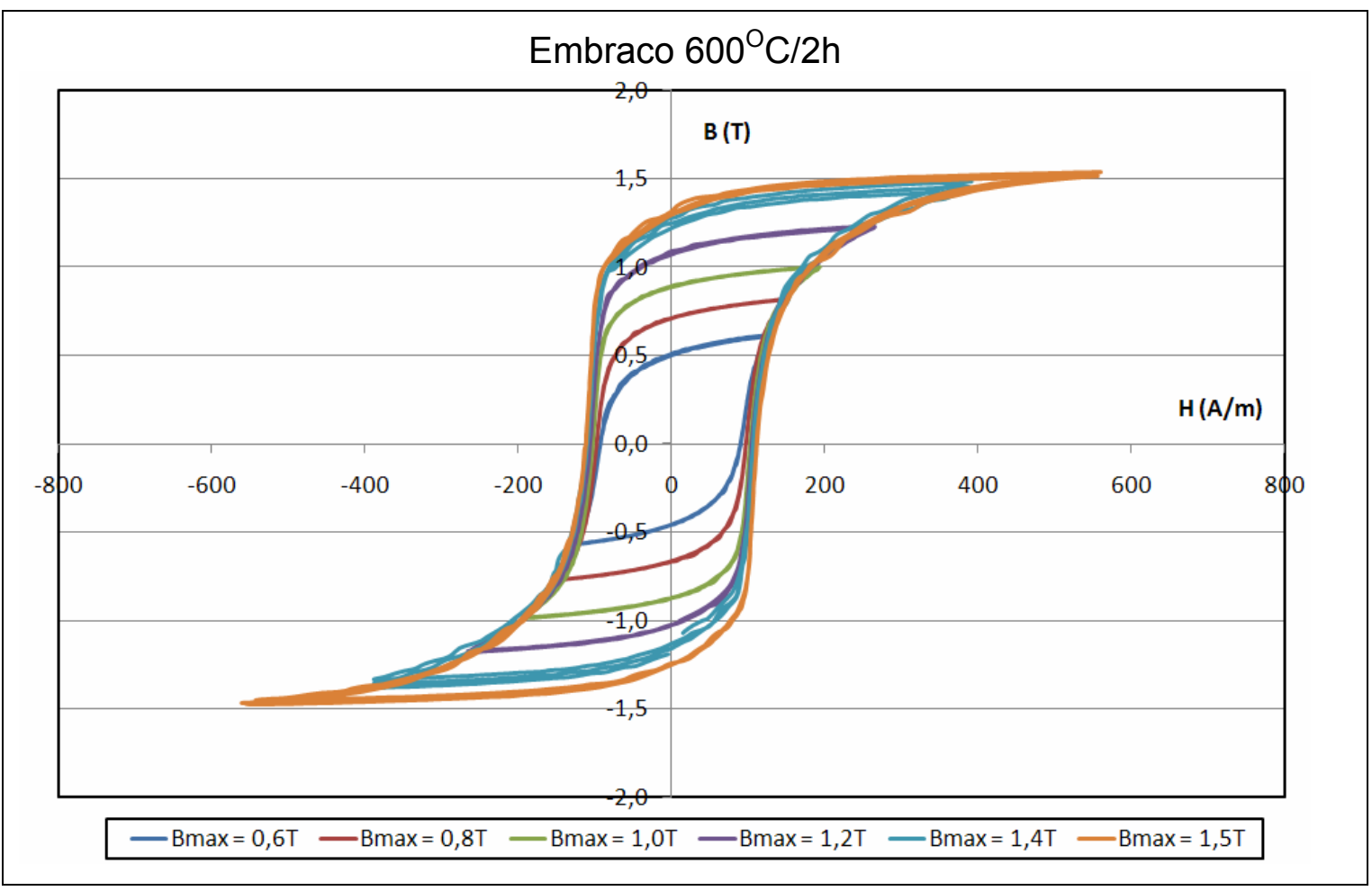


99
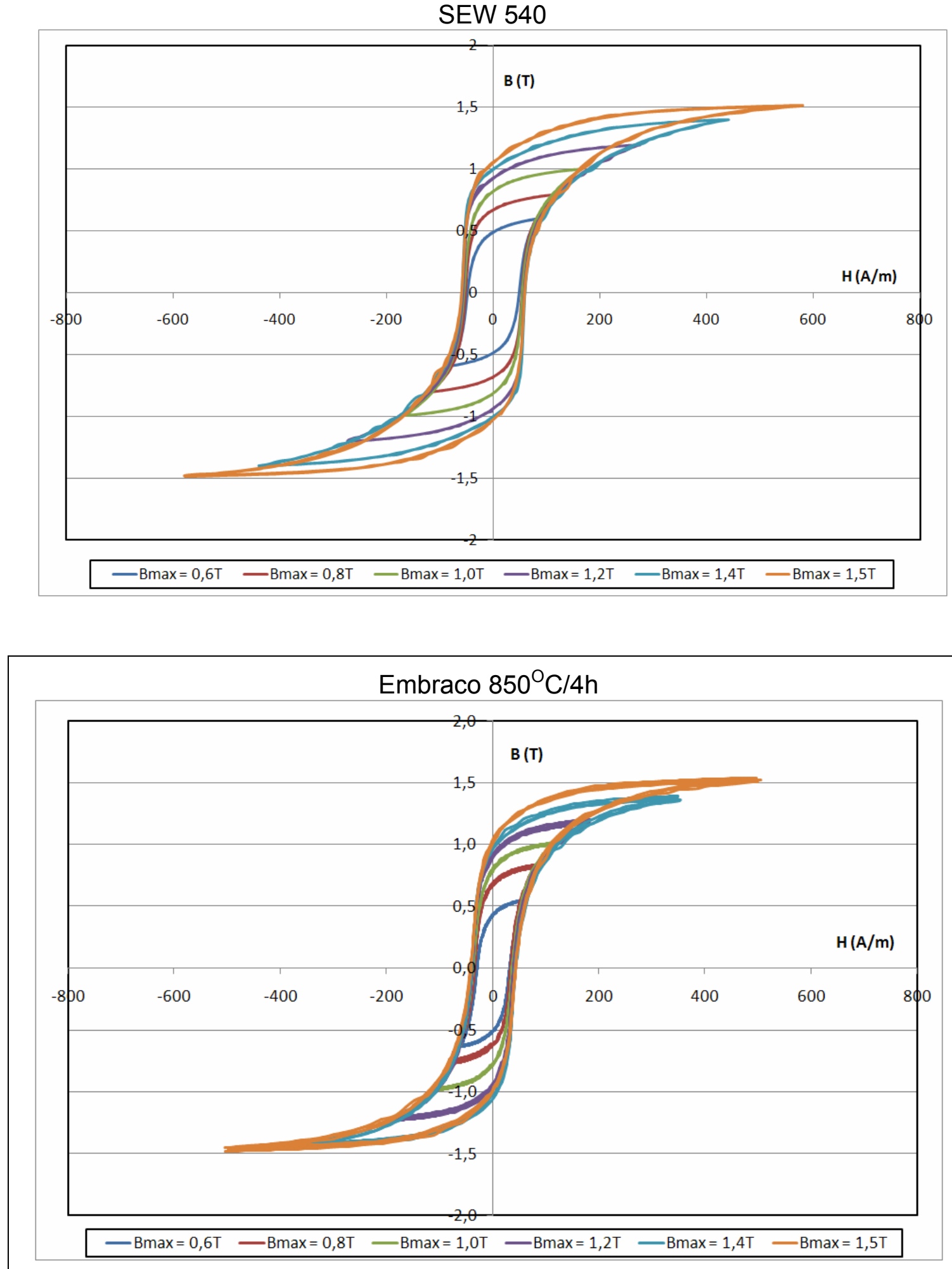


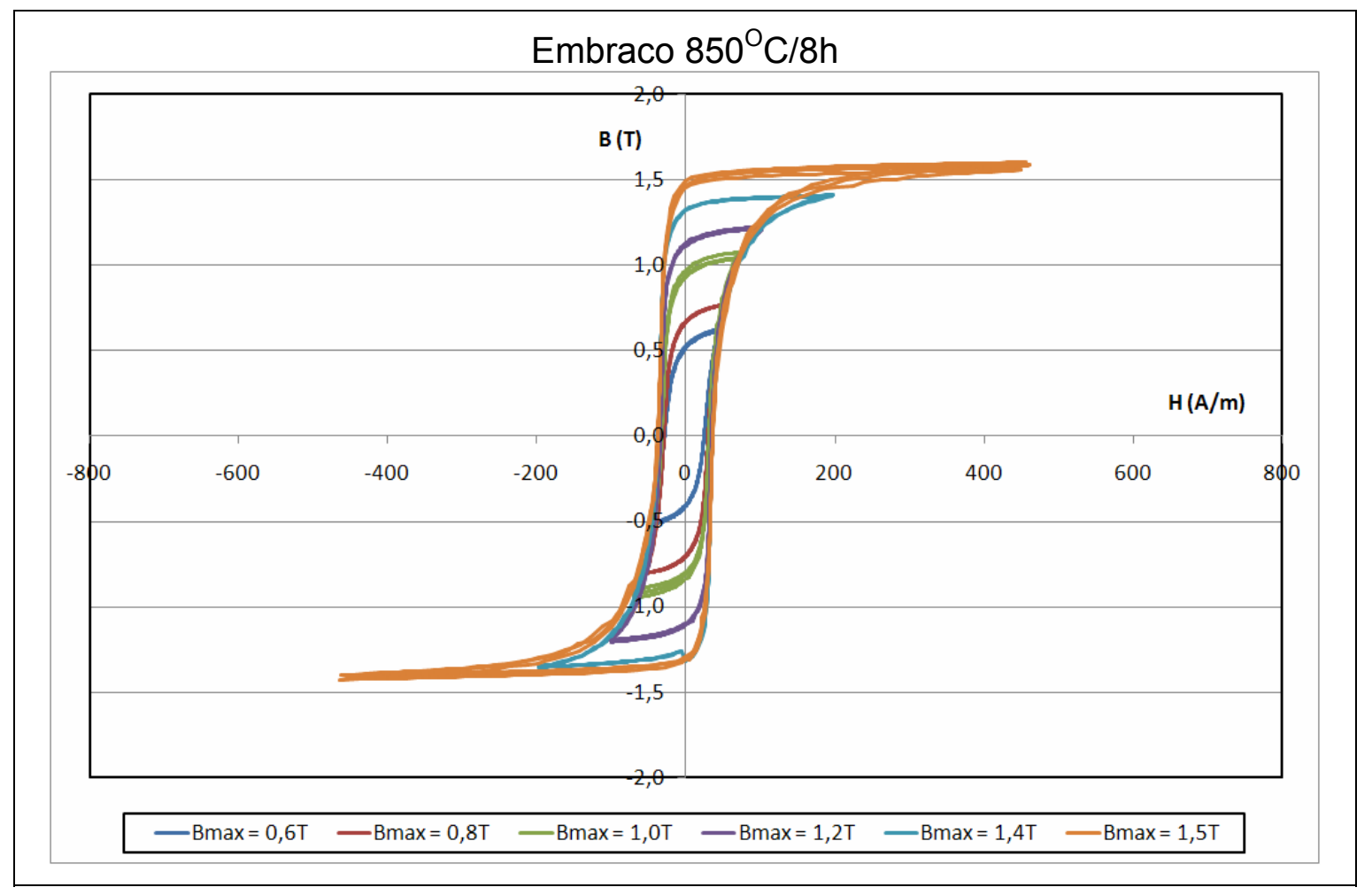

7.2 Histerese das amostras com aumento de tamanho de grão por recristalização.

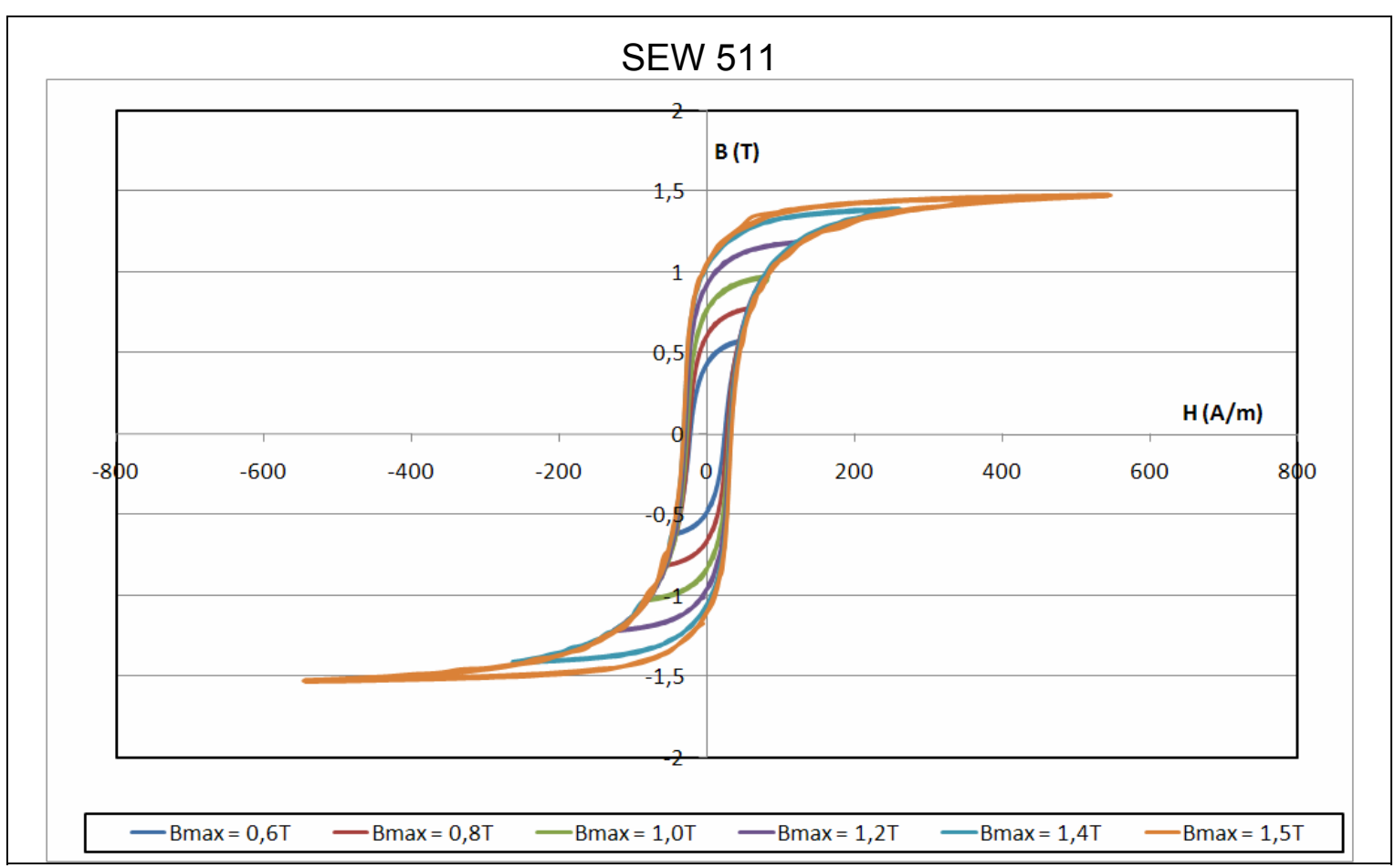



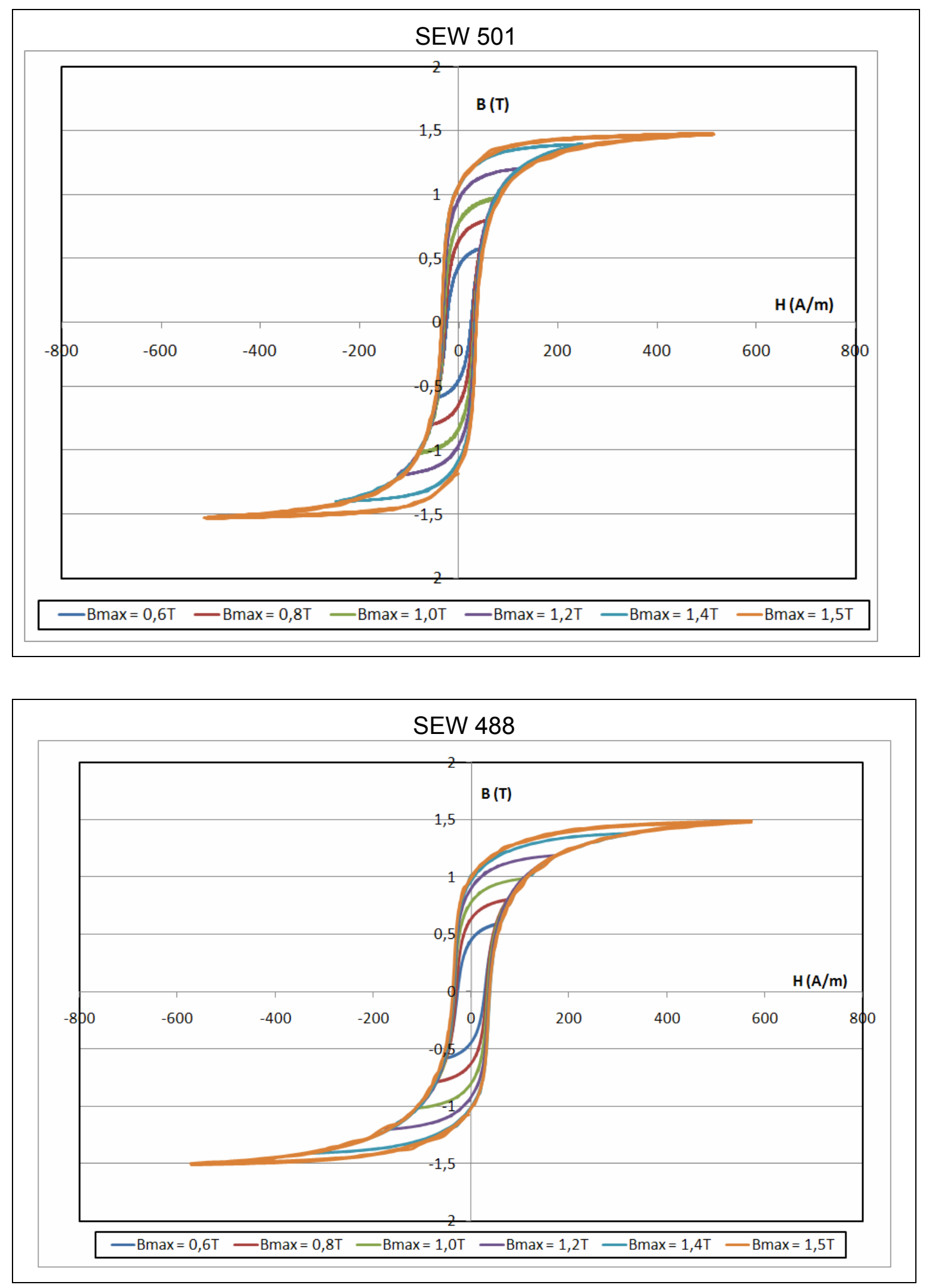

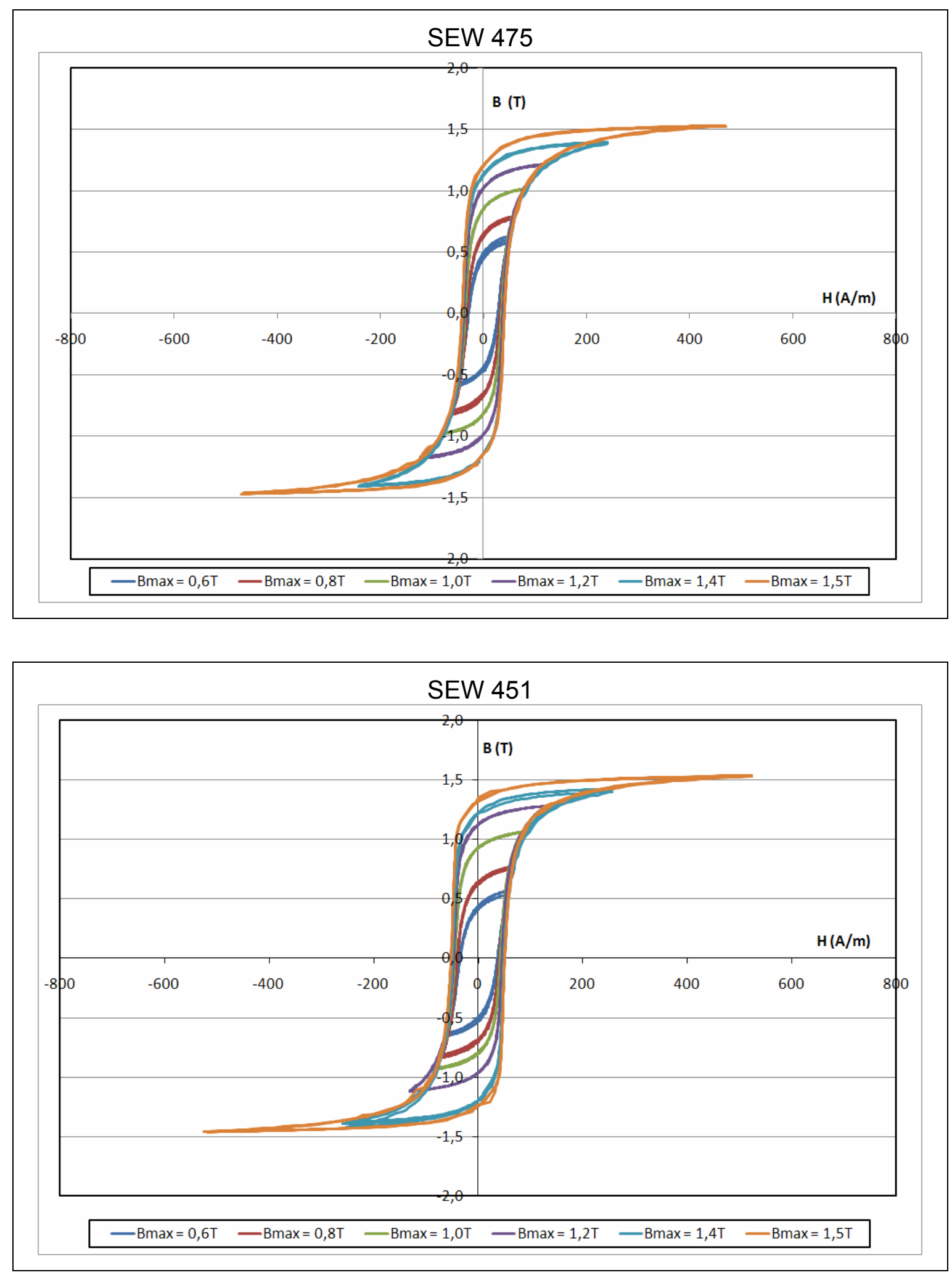

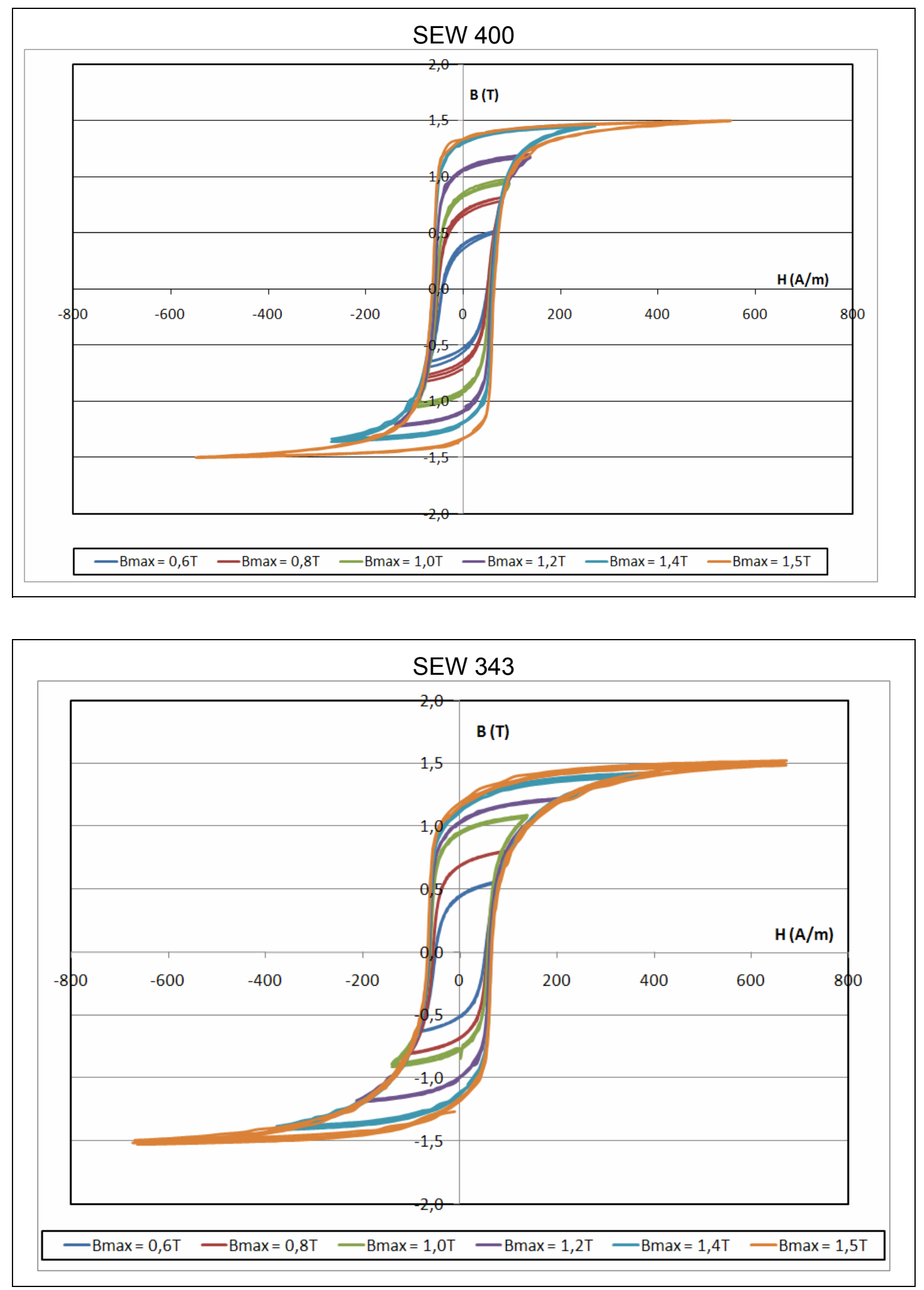